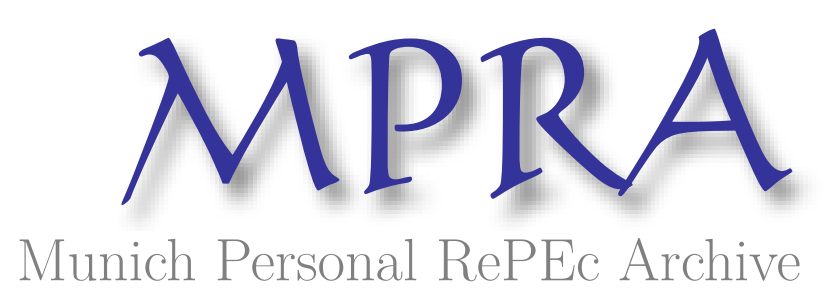

\title{
Proposal for a New Economic Framework Based On Islamic Principles
}

Shaikh, Salman Ahmed

Islamic Economics Project

17 April 2010

Online at https://mpra.ub.uni-muenchen.de/23000/

MPRA Paper No. 23000, posted 04 Jun 2010 10:23 UTC 


\section{PROPOSAL FOR A NEW \\ ECONOMIC FRAMEWORK \\ BASED ON ISLAMIC PRINCIPLES}

\section{Salman Ahmed Shaikh}

PhD in Progress, MS (Szabist), BBA (Bahria University)

Director, Islamic Economics Project

Assistant Professor, University of East 
Proposal for Islamic Economic Framework

Dedicated to
My Parents and Teachers

(C) All Copyrights Reserved by Islamic Economics Project 


\section{Preface}

This text is a preliminary account of my ongoing research on Islamic Economic System. I took up this project in 2004 when I started my under-graduation at Bahria University, Pakistan. The inspiration for the project came from my personal affiliation with Jamia Dar-ul-Uloom, Hyderabad, Pakistan for 6 years where I completed Hifz-e-Quran with the grace of Allah. I was always interested in Islamic studies, but when I decided to pursue higher education in Business and Finance, I felt that luckily I possess the needed aptitude and dedication to contribute in the field of Islamic economic and financial system. I do not claim to be an expert in Islamic studies nor in Finance and Economics. The recommendations presented in this book have the sole objective of presenting ideas that can cure our socio-economic ills before the general readers, religious scholars, economists and policymakers. The objective is not to infer and endorse, but to seek solutions to our chronic socio-economic ills in the framework of Islamic principles.

I was born in Karachi, but my schooling and college education was completed in Hyderabad that is 160 miles north east of Karachi. I have had a very unique educational background. I have studied in Madrasa, a private school and then in a semi-government university. In Madrasa, I learnt Quran by heart. I came to Karachi to pursue Higher Education in 2004 and graduated Cum Laude in 2008 from Bahria University specializing in Finance. I did my MS in 2010 from Szabist, Karachi. Currently, I am pursuing my PhD in Islamic Economics.

My academic interests include research in Economics and Finance and have published academic books to my credit. I wrote a book on 'Mathematical Economics' and 'Economy of Pakistan' for Commerce Publications, Karachi. I was awarded a commendation certificate on writing a manuscript for a book "Industries of Pakistan" by National Book Foundation. I have written 12 research papers to date.

The published research work includes a research paper on "A Brief Review of Practiced Islamic Finance" published in Journal of Law \& Religion, Hemline, USA. A research paper on "Analysis of Stock Screening Principles in Islamic Mutual Funds Industry" was published in True Banking Magazine in March 2010.

A research paper on "Role \& Functions of Central Bank in Islamic Finance" was presented at $14^{\text {th }}$ National Research Conference at Szabist in December 2009.

A research article titled "An Alternate Approach to Practiced Islamic Finance" was published in Accountancy Magazine in February, 2010. A research article titled "A Critical Analysis of Islamic Banking" was published in Accountancy Magazine in July, 2007.

Besides, I was also the Editor of Bahria Economic Magazine from September 2007 to June 2008. I have conducted various guest speaker sessions on Islamic Economics at various national universities and other forums. Currently, I am working as Assistant Professor at University of East. I have also instigated a 


\section{Proposal for Islamic Economic Framework}

research project on Islamic Economics and am seeking collaboration with research bodies in this area to promote and further the research work in this field.

My principal issues of interest are 'poverty' and 'inequality'. Both these problems are pertinent to developing countries like Pakistan. In Pakistan, 25\% of the people live below the line of poverty according to the government statistics. There is huge income inequality with $20 \%$ of the rich, affluent and resourceful class occupying $80 \%$ of the country's wealth.

Income inequality leads to social stratification. Class divide expands into social relations like marriages and professional relations in the form of nepotism. National cohesion and collective work towards national goals is overlooked. Classes exist to consolidate their own existence and vested interests. Only shortterm policies are pursued and that too on the direction of International agencies like IMF and World Bank. Policies even though proven effective in one system need modification sometimes to be effective in another system with a different set of characteristics.

Short-term orientation leads to economic growth in patches but without any longterm orientation towards capacity building and infrastructural development, the growth is unsustainable. Therefore, poverty and inequality persist in the society. Poverty and inequality lead to illiteracy, inadequate health conditions and poor standards of living in general. Education, health, sanitation and adequate standards of living can all be provided if the country has enough income and if that income is distributed fairly equally. Conversely, if there is low per capita income and if it is distributed unequally, the basic amenities of life cannot be provided to the masses.

Fundamental problems of developing countries and since developing countries make up most of the world's population; the fundamental problems of world can generally be categorized under 'poverty' and 'inequality' in the $21^{\text {st }}$ century. However, it is overshadowed by its consequences in the form of terrorism, poor health and sanitation facilities and illiteracy.

Income inequality stems from wealth inequality. Direct taxation should not only focus upon income but also on wealth using the institution of Zakat. Documentation of the economy is necessary to make facts based effective policies. Unbridled fiscal expansion through desperate deficit financing only increases leverage in the economy and even put its existence at risk. It only delays the inevitable and the central issues remain unresolved. Documentation is necessary to increase the tax base and the size of the formal sector.

I have always been open to diversity in ideas, culture and society. I have the habit of accepting something different in favor of rejecting some of my former views if anyone can prove them wrong. I have always maintained that issues should be resolved through intellectual reasoning. 
I would like to take this opportunity to thank my parents and grandmother for their support right throughout my life. I would also like to thank my teachers especially Qari Khalil Ur Rehman (Senior Faculty, Jamia Dar-ul-Uloom, Hyderabad) and Qari Sher Ali Khan (Senior Faculty, Jamia Dar-ul-Uloom, Hyderabad), Mr. Mansoor (Senior Faculty, City Foundation High School, Hyderabad), Mr. Shakeel (Senior Faculty, Saifee College, Hyderabad), Mr. Akbar Saeed (Associate Professor, Bahria University), Mr. Naveed M. Khan (Head of Department, Management Sciences, Bahria University), Ehsan Shaikh (Senior Faculty, Bahria University), Mr. Khalid Khawar (Professor, Bahria University), Mr. Salman A. Khan (Associate Professor, Bahria University), Mr. Wajid Hanfi (Senior Faculty, Bahria University), Mr. Ahsan Hussain (Professor, Szabist, Karachi), Dr. Amanat Ali Jalbani (Dean, Szabist, Karachi), Mr. Shan Saeed (Head of External Affairs, Szabist, Karachi) and Mr. Faysal Abdullah (CEO, BMC Pakistan \& Senior Faculty, Szabist, Karachi).

I would also like to thank Dr. Khalid Zaheer (Dean, University of Central Punjab), Dr. Muhammad Nadeem Hanif (Additional Director, Research Department, State Bank of Pakistan) and Dr. Muhammad Nejat Ullah Siddiqui - who is one of the pioneer researchers in Islamic Economics - for their valuable comments and suggestions as well as answering some of my queries diligently.

The readers' comments, guidance and criticism will enrich my knowledge and give me the chance to further sharpen my knowledge base and convert these ideas into practicable models for the development of our people.

Salman Ahmed Shaikh

Email: salmanahmed_hyd@hotmail.com

Web: www.islamiceconomics.viviti.com

Contact No. +92-0334-3193395 


\section{Table of Contents}

Preface 3

INTRODUCTION 10

An Overview of Global Development Problems.

Challenge of Economic Development in Pakistan

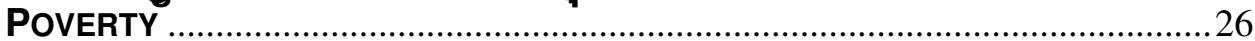

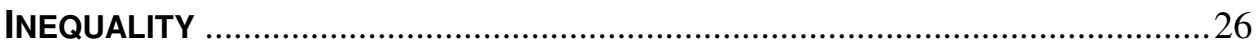

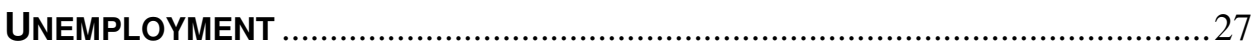

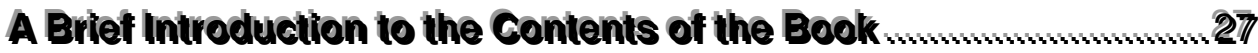

THESIS OF RELIGION..................................................29

Evidence of Muhammad's Prophet Hood in Religious Seriptures w...35 Where Abrahamic Religions Disagree? Muhammad (PBUH) in the eyes of non-Muslims wwswswswswswswsw. 37

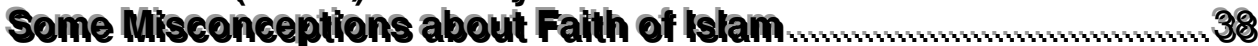

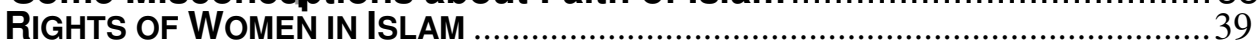

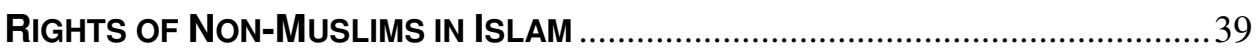

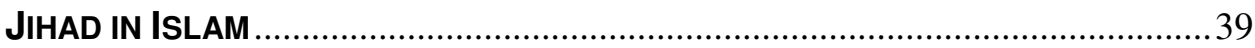

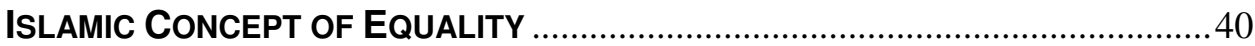

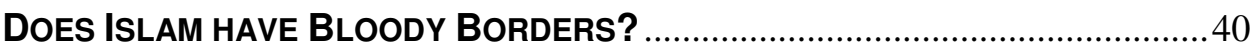

ISLAMIC ECONOMIC TEACHINGS...................................42

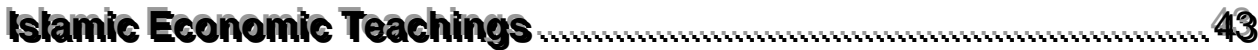

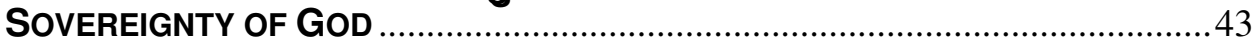

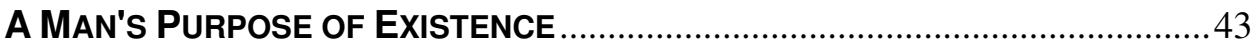

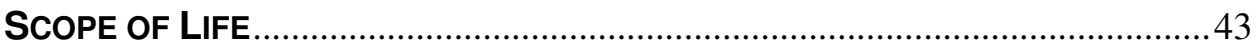

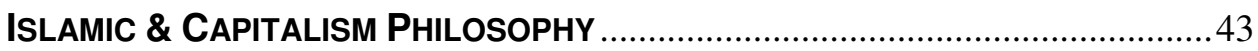

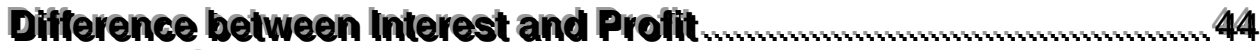

How This System Works …m.w

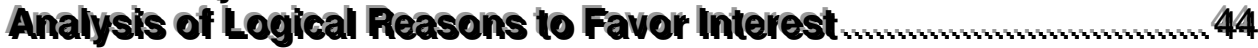

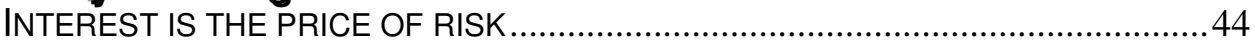

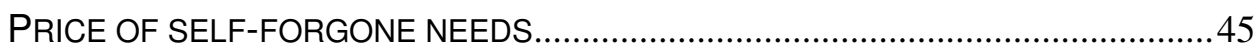

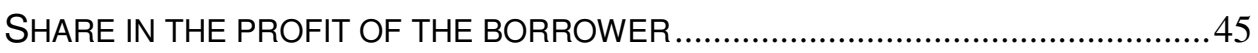

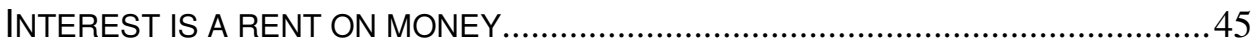

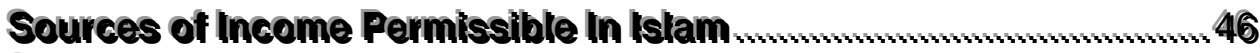

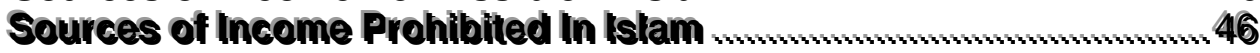

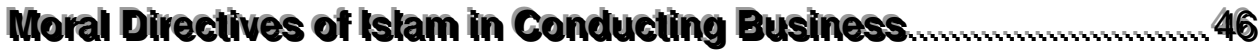

(C) All Copyrights Reserved by Islamic Economics Project 6 


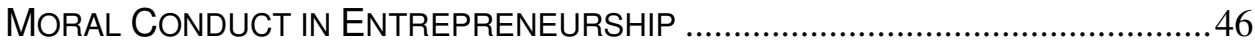

ISLAMIC TEACHINGS AND UNETHICAL TRADE PRACTICES...............................47

FUTURES \& FORWARD TRADING: ISLAMIC VIEW .........................................48

ANALOGICAL DEDUCTION IN MATTERS: ISLAMIC VIEW ..................................4 48

BENEFITS OF HONEST CONDUCT IN PARTNERSHIP .......................................48

THE IMPORTANCE OF PAYING ONE'S LIABILITY .............................................48

JOB RESPONSIBILITY OF EMPLOYEE: ISLAMIC VIEW....................................49

RESPONSIBILITY OF EMPLOYER: ISLAMIC VIEW ............................................49

GENDER \& ETHNIC DISCRIMINATION: ISLAMIC VIEW .......................................49

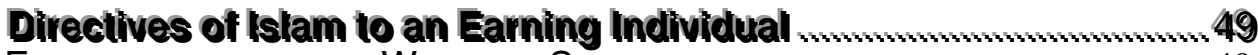

ENCOURAGEMENT FOR WELFARE SPENDING .........................................49

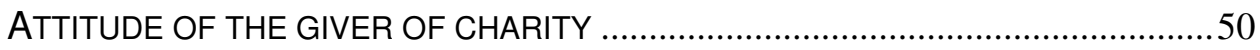

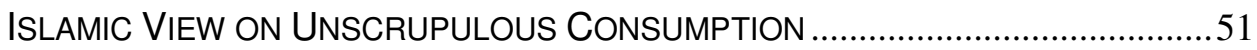

STINGINESS \& WEALTH ACCUMULATION: ISLAMIC VIEW ..................................51

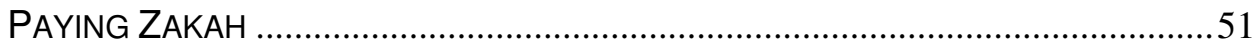

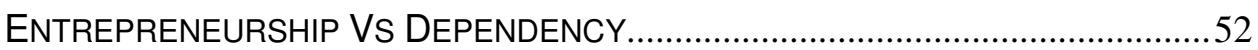

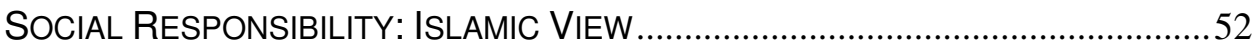

COMMUNAL DEVELOPMENT: ISLAMIC VIEW .............................................52

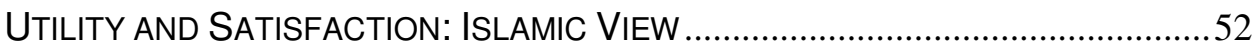

Analysis of Economic Practices in light of Istamic Prinelples ...... 5 ?

ECONOMIC SYSTEMS .55

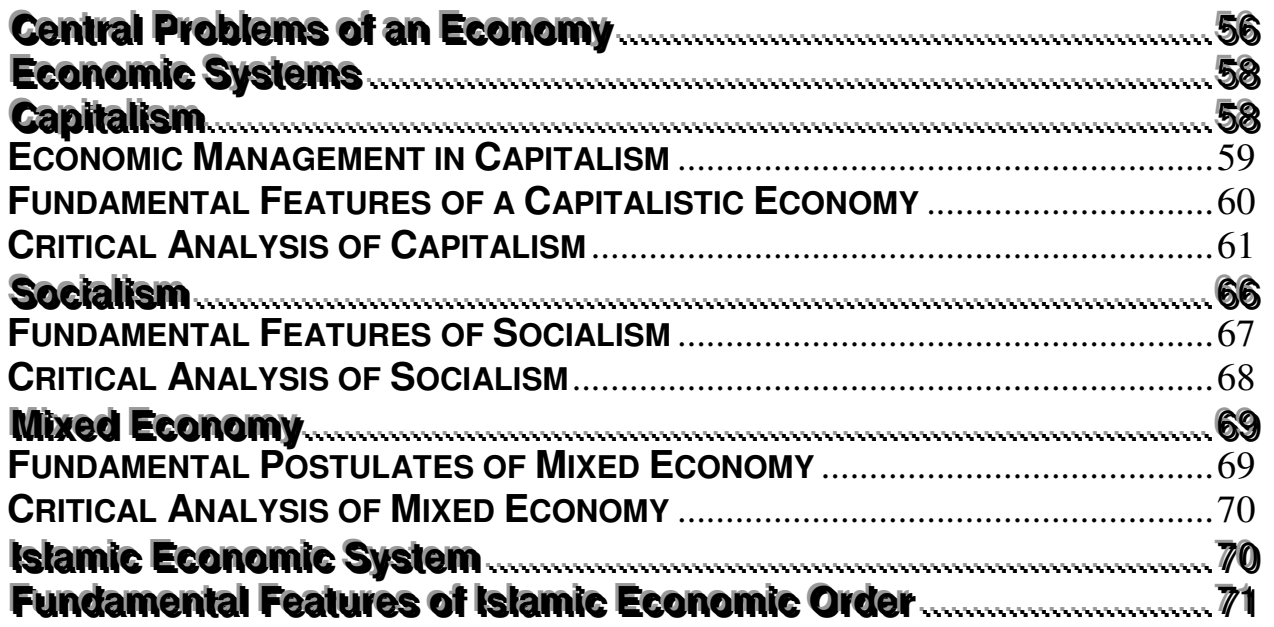

ISLAMIC FISCAL POLICY .............................................73

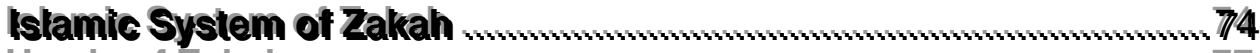

Heads of Zakah .

(C) All Copyrights Reserved by Islamic Economics Project 7 
Institution of Zakah: Vital Source of Public Finance in Istamic

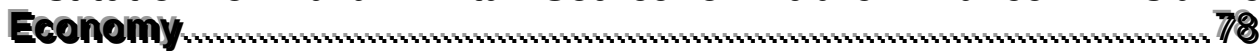
Issues in Estimation of Zakah $\ldots \ldots \ldots \ldots \ldots \ldots \ldots \ldots \ldots \ldots \ldots \ldots \ldots \ldots \ldots \ldots \ldots \ldots \ldots .79$

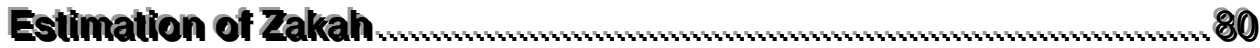

Calculation of Nisab for Individuals (Exemption Amount) …............ 82

Economic Results of Islamic Fiscal Retorms ….............................. 85

Fiseal Reterms and the Fiscal Defleit .

Eftects of Fiscal Polley on Property Market …....................................90

Eftects of Fiscal Policy on Investment ....................................... 91

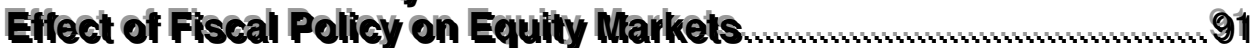

Eftects of Fiscal Policy on Iniltation .........................................

Non-Tax Revenues ….............................................................. 92

Funding Non-Revenue Generating Activities ……….................... 93

Alternative for Public Finance Other Than Zakah . .......................... 93

Conelusion ............................................................5

ISLAMIC MONETARY Policy .96

Salient Features of islamic Monetary Regime ………................. 97

1. INTEREST FREE ECONOMY …………………………………………........97

3. LOW TO MODERATE INFLATION..............................................................97

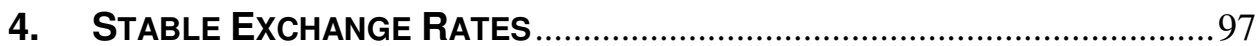

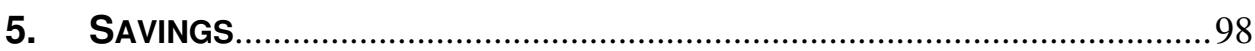

Dealing with Scarcity of Capital .....................................................

Role of Central Bank in an istamic Economy ….............................. 101

Central Banking Practices in Muslim Countries ............................... 105

Alternative for Public Finance Other Than Zakat $\ldots . . . . . . . . . . . . . . . . . . . . .1111$

CURRENT ISLAMIC BANKING....................................114

Assets: Finaneing, Advances Investments

DIMINISHING MUSHARAKAH ..........................................................................116

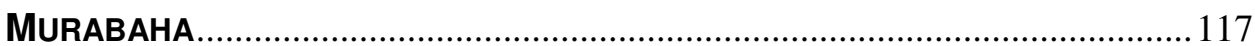

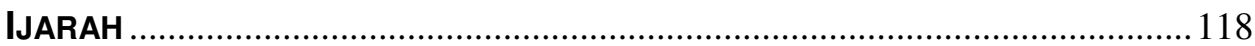

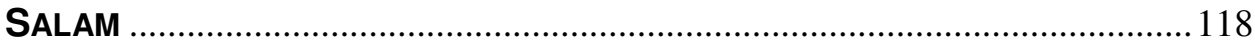

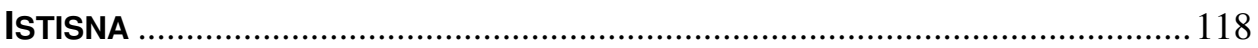

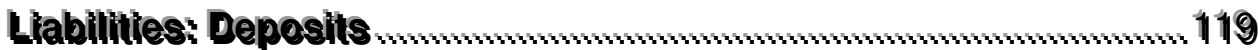

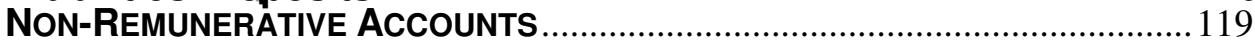

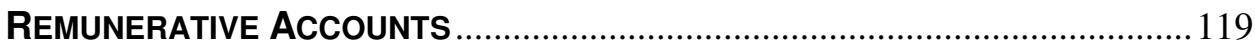

Proposal for Financial Framework ....................123

(C) All Copyrights Reserved by Islamic Economics Project 8 


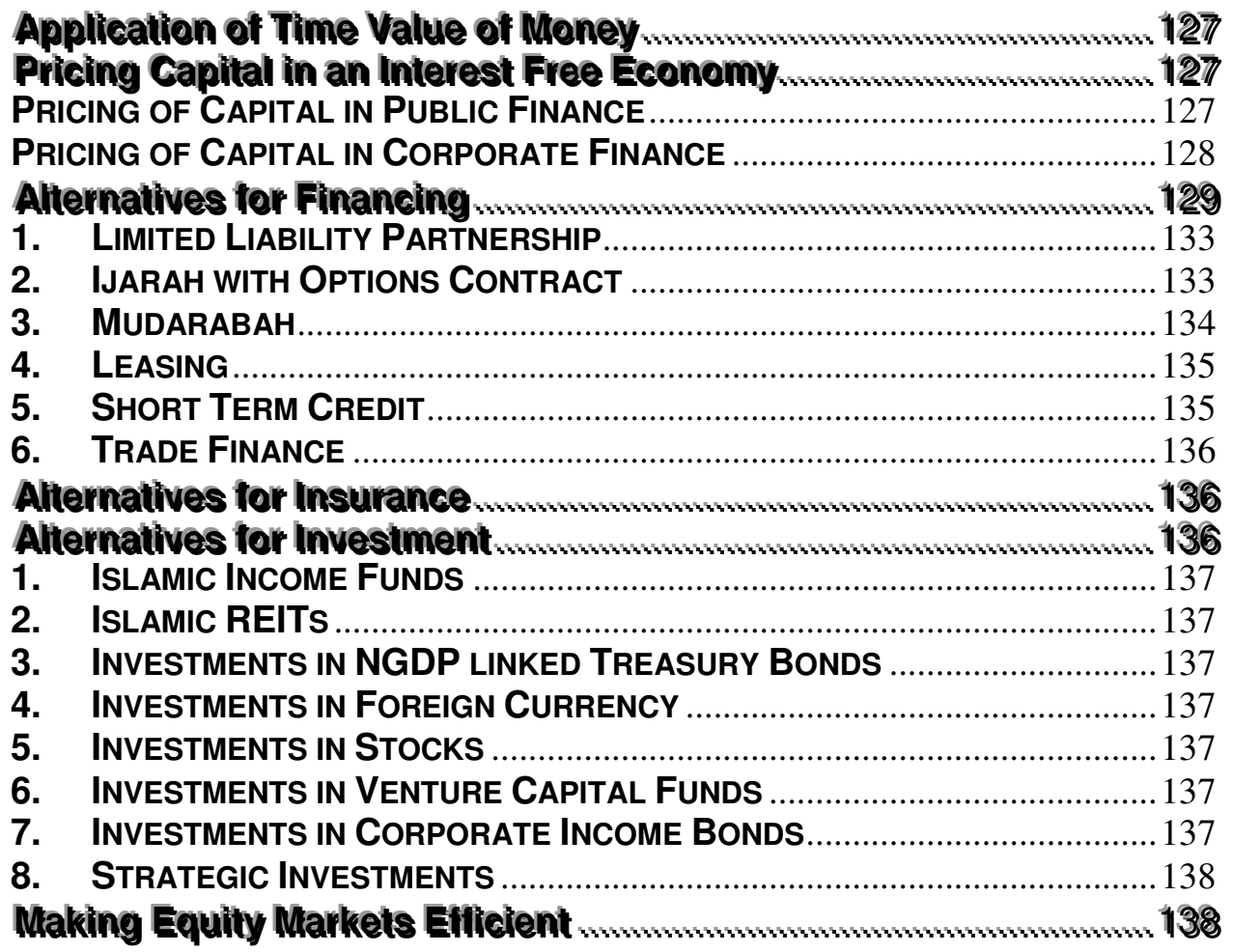

MICRO CREDIT IN AN ISLAMIC ECONOMY.....................140

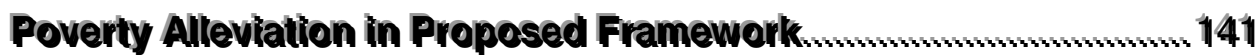

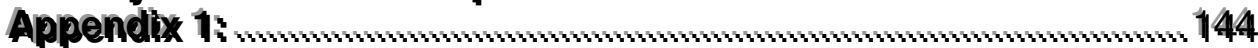

Appendix 2: Looking tor New Steps in Islamie Finance wwwwww 146

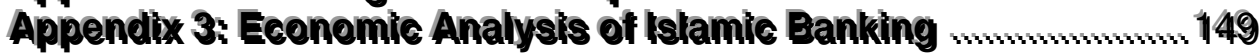

REFERENCES .....................................................159 


\section{Chapter 1}

\section{INTRODUCTION}


Capitalism, unlike Islamic economic system and Socialism regards capital as an individual factor of production creditable of a distinct factor payment i.e. interest. It supports the capitalists to benefit from wealth accumulation without having to put factor i.e. capital at similar risks that an entrepreneur faces. It shifts the break even line further away from the entrepreneur and crowds out entrepreneurs who cannot afford to keep feeding capitalists. In this regard, interest has a huge influence on allocation of resources. It influences the basic economic decisions like what and for whom to produce.

Capital is needed for technological advancements. It is needed for production and consumption and for governments to expend on development. It is even needed to influence policies by winning elections after expensive election campaigns. There would not have been many complexities if markets were efficient and income and wealth distribution fair. But, the world we live in has never and perhaps never will have perfect equality and perfect competition. In fact, as per Islam, business cycles must exist as this world is a place for test and the nature of this test is such that some people become privileged and some left behind. Both are tested for patience and thankfulness to Allah and how they take care of society and its needs. But, interest as a system of allocation of resources ensures a fixed return to one and uncertain for another. That is why, business cycles affect borrowers, leveraged companies and debt-ridden countries adversely. Equity financing as in the Islamic model of Mudarabah and Musharakah ensures justice and equity (as far as is naturally possible without interfering with the nature of this test and not contradicting with the values of justice).

Interest serves capitalists and allows them to accumulate wealth. This is evident from the empirical statistics on inequality in income and wealth in second half of the $20^{\text {th }}$ century when monetary capitalism with institutional support expanded in an increasingly integrated and global economy. Hence, much of the technological advancements, increase in production and better standards of living with increase in earning opportunities and welfare expenditure has occurred in that part of the world which was able to accumulate capital effectively than the rest of the world in pre-capitalistic and early capitalistic eras.

Monetarists view inflation as a monetary phenomenon. They advocate inflation targeting through monetary policy. However, in most developing countries, tight monetary policy has not resulted in disinflation. Even the case of a developed economy such as USA does not support quantitative theory of money in late 20th century proposed by Fischer.

Real interest rates for depositors in most developing countries are negative. Hence, savings have not been solely dependent upon and motivated by level of interest rates. Interest based commercial banking cannot solely be supported on the premise of intermediation function that it performs which eliminates or at least limit the problem of adverse selection and moral hazard. However, this intermediation function is also performed by equity funds and REITs. Thus, debt over equity is preferred not necessarily due to the intermediation function, but due to risk aversion. Nevertheless, with negative real returns, unnecessary risk aversion does not seem that attractive an approach. Consequently, equity 
financing is also used widely. Effective and efficient intermediation in equity mode of financing with developments in equity funds and venture capital funds can mitigate the risk even more effectively.

Inflation depreciates the value of money and hence reduces the purchasing power of consumers. Inflation in this respect acts as a tax for the consumer, but not so much helpful for the government as it does not entirely go to the exchequer. However, nominal value of tax revenue increases with inflation. But, government is also a consumer in an economy and a more significant one in a developing economy as suggested by Keynes.

Inflation is beneficial to the borrower and puts lender at a disadvantage. Criticisms on interest on the sole premise that lender for interest being always at an advantage cannot make a sufficient economic case for prohibition of interest in value-neutral economics.

Interest is prohibited in all monotheist religions. However, interest is pervasive in capitalism, an economic system based on secular ideals. Much of criticism on interest, capitalism and its ideals has been made without reference to developments in contemporary systems and institutions. In proposing alternative to Capitalism, an idealistic approach is adopted. This chapter goes beyond critical analysis of current economic regimes and practices to analyze and propose alternative need-fulfillment mechanisms in both monetary and fiscal economics.

\section{An Overview of Global Development Problems}

The major problems in Economic Development of any country include poverty, inequality and unemployment. All other problems are more or less a result of the above-mentioned problems or the manifestation of these problems. Problems like terrorism and political instability that apparently seem unrelated to economics are also a consequence of poverty, inequality and unemployment. In the following pages, some pertinent development statistics obtained from World Development Indicators, 2005 published by World Bank are provided.

As can be seen from Table 1 through Table 4, the number of people living in poverty declined in the last two decades; however, people living in poverty rose in Latin America, Sub Saharan Africa, Central and South Asia. 


\section{Proposal for Islamic Economic Framework}

Table1: Number of people living below poverty line i.e. $\$ 1$ (millions)

\begin{tabular}{|l|r|r|r|r|r|r|r|r|}
\hline Region & 1981 & 1984 & 1987 & 1990 & 1993 & 1996 & 1999 & 2001 \\
\hline East Asia \& Pacific & 796 & 562 & 426 & 472 & 415 & 287 & 282 & 271 \\
\hline China & 634 & 425 & 308 & 375 & 334 & 212 & 223 & 212 \\
\hline Europe \& Central Asia & 3 & 2 & 2 & 2 & 17 & 20 & 30 & 17 \\
\hline Latin America \& Caribbean & 36 & 46 & 45 & 49 & 52 & 52 & 54 & 50 \\
\hline Middle East \& North Africa & 9 & 8 & 7 & 6 & 4 & 5 & 8 & 7 \\
\hline South Asia & 475 & 460 & 473 & 462 & 476 & 461 & 429 & 431 \\
\hline Sub-Saharan Africa & 164 & 198 & 219 & 227 & 242 & 271 & 294 & 313 \\
\hline Total & 1,482 & 1,277 & 1,171 & 1,218 & 1,208 & 1,097 & 1,096 & 1,089 \\
\hline Excluding China & 848 & 852 & 863 & 844 & 873 & 886 & 873 & 877 \\
\hline
\end{tabular}

Source: World Bank's Development Research Group

Table2: People in population living below poverty line i.e. $\$ 1(\%)$

\begin{tabular}{|l|r|r|r|r|r|r|r|r|}
\hline Region & \multicolumn{1}{|c|}{1981} & 1984 & 1987 & 1990 & 1993 & 1996 & 1999 & 2001 \\
\hline East Asia \& Pacific & 57.7 & 38.9 & 28 & 29.6 & 24.9 & 16.6 & 15.7 & 14.9 \\
\hline China & 63.8 & 41 & 28.5 & 33 & 28.4 & 17.4 & 17.8 & 16.6 \\
\hline Europe \& Central Asia & 0.7 & 0.5 & 0.4 & 0.5 & 3.7 & 4.3 & 6.3 & 3.6 \\
\hline Latin America \& Caribbean & 9.7 & 11.8 & 10.9 & 11.3 & 11.3 & 10.7 & 10.5 & 9.5 \\
\hline Middle East \& North Africa & 5.1 & 3.8 & 3.2 & 2.3 & 1.6 & 2 & 2.6 & 2.4 \\
\hline South Asia & 51.5 & 46.8 & 45 & 41.3 & 40.1 & 36.6 & 32.2 & 31.3 \\
\hline Sub-Saharan Africa & 41.6 & 46.3 & 46.8 & 44.6 & 44 & 45.6 & 45.7 & 46.4 \\
\hline Total & 40.4 & 32.8 & 28.4 & 27.9 & 26.3 & 22.8 & 21.8 & 21.1 \\
\hline \multicolumn{1}{|c|}{ Excluding China } & 31.7 & 29.8 & 28.4 & 26.1 & 25.6 & 24.6 & 23.1 & 22.5 \\
\hline
\end{tabular}

Source: World Bank's Development Research Group

In Table 3 and 4 , instead of defining poverty line at $\$ 1$, it is raised to $\$ 2$. People earning $\$ 2$ are still poor even if not extreme poor. 


\section{Proposal for Islamic Economic Framework}

Table 3: People in population living below poverty line i.e. $\$ 2$ (millions)

\begin{tabular}{|l|r|r|r|r|r|r|r|r|}
\hline Region & 1981 & 1984 & 1987 & 1990 & 1993 & 1996 & 1999 & 2001 \\
\hline East Asia \& Pacific & 1,170 & 1,109 & 1,028 & 1,116 & 1,079 & 922 & 900 & 864 \\
\hline China & 876 & 814 & 731 & 825 & 803 & 650 & 627 & 594 \\
\hline Europe \& Central Asia & 20 & 18 & 15 & 23 & 81 & 98 & 113 & 93 \\
\hline Latin America \& Caribbean & 99 & 119 & 115 & 125 & 136 & 117 & 127 & 128 \\
\hline Middle East \& North Africa & 52 & 50 & 53 & 51 & 52 & 61 & 70 & 70 \\
\hline South Asia & 821 & 859 & 911 & 958 & 1,005 & 1,029 & 1,039 & 1,064 \\
\hline Sub-Saharan Africa & 288 & 326 & 355 & 382 & 410 & 447 & 489 & 516 \\
\hline Total & 2,450 & 2,480 & 2,478 & 2,654 & 2,764 & 2,674 & 2,739 & 2,735 \\
\hline Excluding China & 1,574 & 1,666 & 1,747 & 1,829 & 1,961 & 2,024 & 2,111 & 2,142 \\
\hline
\end{tabular}

Source: World Bank's Development Research Group

Table 4: People in population living below poverty line i.e. $\$ 2(\%)$

\begin{tabular}{|l|r|r|r|r|r|r|r|r|}
\hline Region & \multicolumn{1}{|c|}{1981} & 1984 & \multicolumn{1}{|c|}{1987} & \multicolumn{1}{|c|}{1990} & 1993 & 1996 & 1999 & 2001 \\
\hline East Asia \& Pacific & 84.8 & 76.6 & 67.7 & 69.9 & 64.8 & 53.3 & 50.3 & 47.4 \\
\hline China & 88.1 & 78.5 & 67.4 & 72.6 & 68.1 & 53.4 & 50.1 & 46.7 \\
\hline Europe \& Central Asia & 4.7 & 4.1 & 3.3 & 4.9 & 17.2 & 20.7 & 23.8 & 19.7 \\
\hline Latin America \& Caribbean & 26.9 & 30.4 & 27.8 & 28.4 & 29.5 & 24.1 & 25.1 & 24.5 \\
\hline Middle East \& North Africa & 28.9 & 25.2 & 24.2 & 21.4 & 20.2 & 22.3 & 24.3 & 23.2 \\
\hline South Asia & 89.1 & 87.2 & 86.7 & 85.5 & 84.5 & 81.7 & 78.1 & 77.2 \\
\hline Sub-Saharan Africa & 73.3 & 76.1 & 76.1 & 75 & 74.6 & 75.1 & 76.1 & 76.6 \\
\hline Total & 66.7 & 63.7 & 60.1 & 60.8 & 60.2 & 55.5 & 54.4 & 52.9 \\
\hline Excluding China & 58.8 & 58.4 & 57.5 & 56.6 & 57.4 & 56.3 & 55.8 & 54.9 \\
\hline
\end{tabular}

Source: World Bank's Development Research Group

In 2001, there were 1,100 million people living in poverty. But in Sub-Saharan Africa, the number of people in extreme poverty rose to 313 million.

Figure 1: People living on less than $\$ 1$ a day (millions) 


\section{Proposal for Islamic Economic Framework}

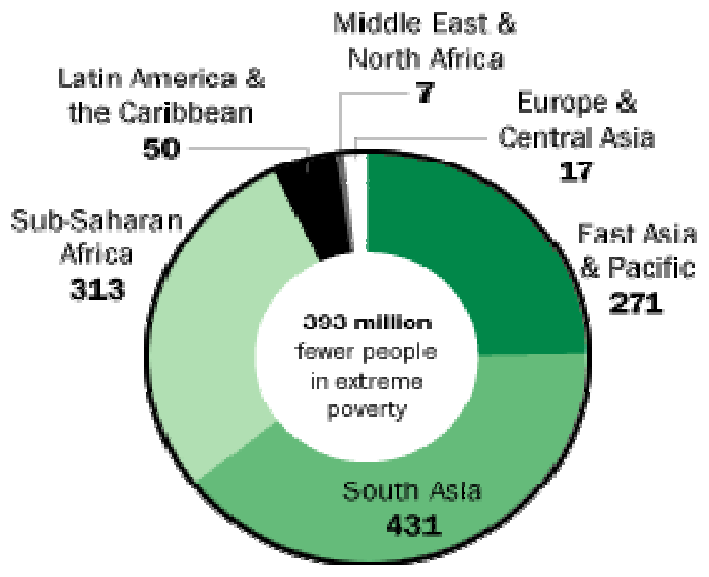

Source: World Bank staff estimates.

As people living in extreme poverty increased in number in Africa, they also became poorer. The average daily income or consumption of those living on less than $\$ 1$ a day fell from 64 cents in 1981 to 60 cents in 2001 . In the rest of the developing world, it increased from 72 cents to 83 cents. Because In SubSaharan Africa, the median share of income going to the poorest 20 percent of the population is 4.9 percent, almost 2 percentage points less than in other developing regions. Only in Latin America and the Caribbean, do the poorest 20 percent fare worse.

Figure 2: Average daily income of the extreme poor (1993 PPP\$)

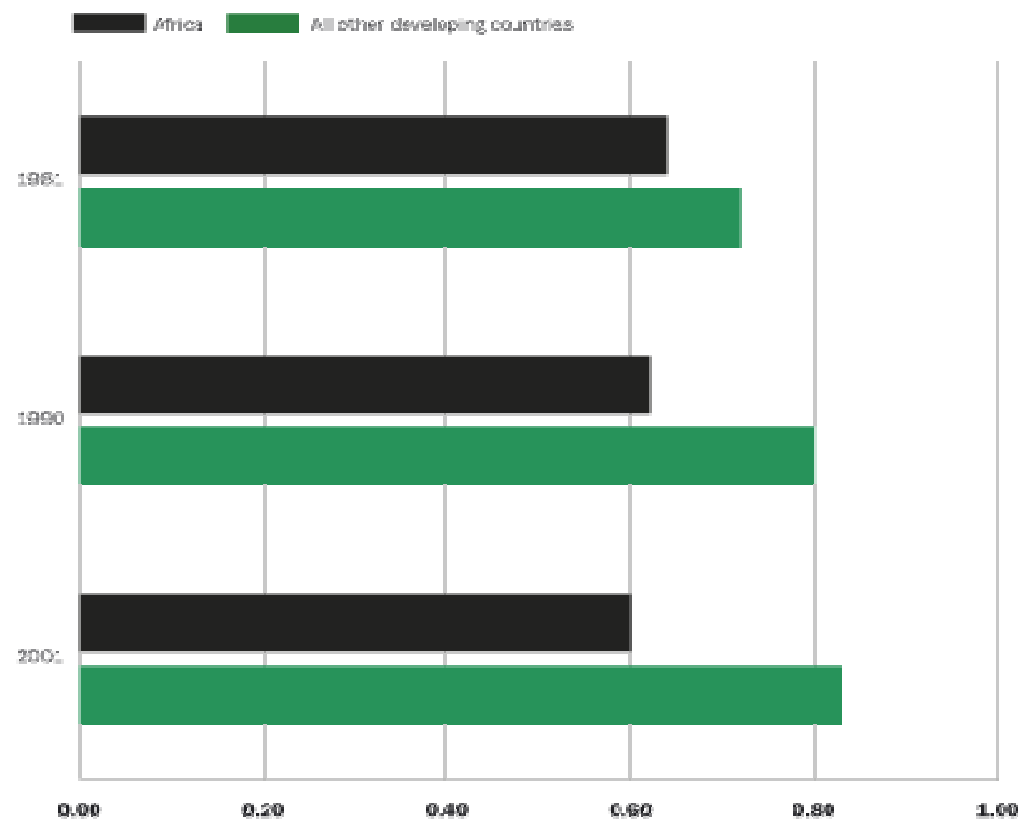

(C) All Copyrights Reserved by Islamic Economics Project 
Source: World Bank staff estimates.

The number of extremely poor people in Sub-Saharan Africa has almost doubled since 1981 to 313 million people in 2001 . This is a terrible human tragedy and represents the greatest challenge to development.

The number living on less than $\$ 2$ a day increased from 2.4 billion in 1981 to 2.7 billion in 2001. The 1.6 billion people in the middle, between the $\$ 1$ and $\$ 2$ a day poverty lines, are still very poor and remain vulnerable to economic slowdowns.

Figure 3: Population living on less than $\$ 1$ a day (millions)

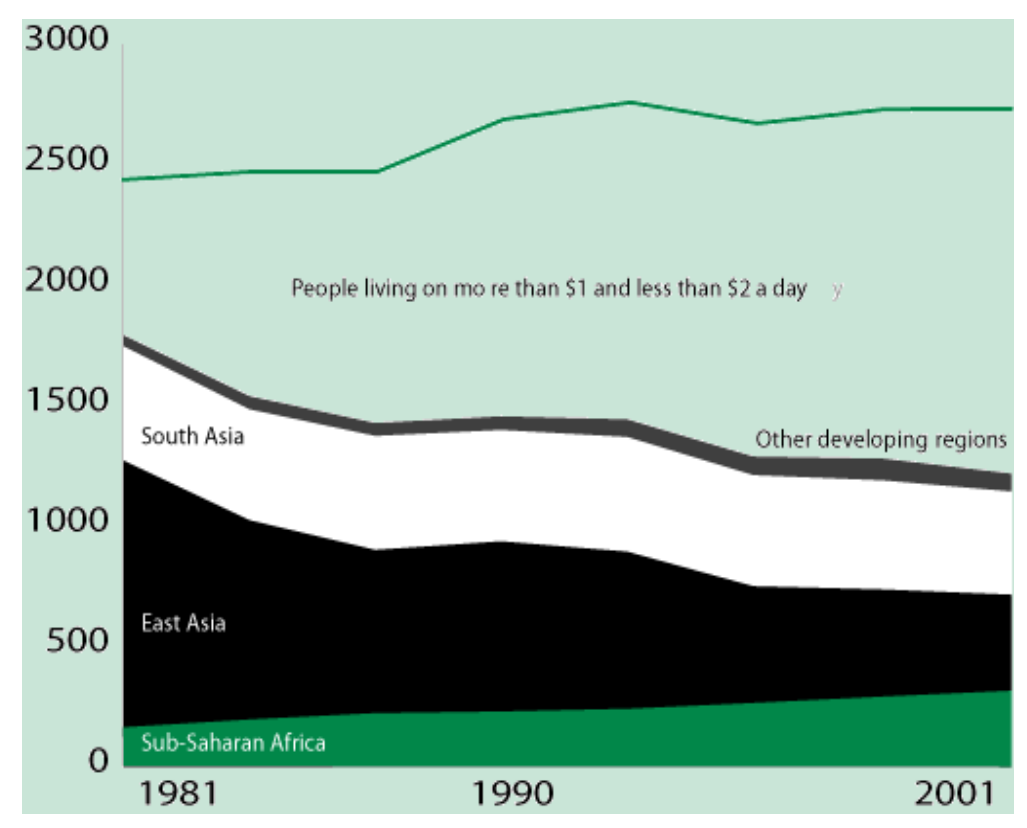

Source: World Bank staff estimates.

In Table 5, it can be observed that highest unemployment rate is usually found in African countries. 


\section{Proposal for Islamic Economic Framework}

Table 5: Countries with Unemployment Rate of more than $20 \%$

\begin{tabular}{|l|c|c|c|c|}
\hline \multicolumn{5}{|c|}{ Adult (15+) unemployment rate } \\
\hline Country or area & Year & Total & Men & Women \\
\hline Albania & 2001 & 23 & 19 & 28 \\
\hline Bosnia and Herzegovina & 2006 & 31 & 29 & 35 \\
\hline French Guiana & 2006 & 29 & 24 & 35 \\
\hline Guadeloupe & 2006 & 27 & 24 & 31 \\
\hline Liberia & 2007 & 6 & 7 & 4 \\
\hline Martinique & 2006 & 25 & 23 & 27 \\
\hline Mauritania & 2000 & 21 & 9 & 41 \\
\hline Montenegro & 2005 & 30 & 26 & 36 \\
\hline Namibia & 2004 & 22 & 19 & 25 \\
\hline Occupied Palestinian Territory & 2007 & 22 & 22 & 19 \\
\hline Reunion & 2006 & 29 & 28 & 30 \\
\hline Saint Lucia & 2004 & 21 & 17 & 25 \\
\hline South Africa & 2007 & 23 & 20 & 27 \\
\hline TFYR of Macedonia & 2007 & 35 & 35 & 36 \\
\hline
\end{tabular}

Source: United Nations Statistics Division

In table 6 , it can be observed that countries with more than 50\% population living in poverty line include mostly African and few Latin American and Central Asian countries. In Zambia, $86 \%$ of the population is living below the poverty line. 


\section{Proposal for Islamic Economic Framework}

Table 6: Countries with more than $50 \%$ people living below poverty line

\begin{tabular}{|l|c|}
\hline \multicolumn{1}{|c|}{ Country Name } & \% of People Below Poverty Line \\
\hline Zambia & 86 \\
\hline Chad & 80 \\
\hline Haiti & 80 \\
\hline Liberia & 80 \\
\hline Sierra Leone & 70 \\
\hline Mozambique & 70 \\
\hline Nigeria & 70 \\
\hline Suriname & 70 \\
\hline Angola & 70 \\
\hline Swaziland & 69 \\
\hline Zimbabwe & 68 \\
\hline Burundi & 68 \\
\hline Niger & 63 \\
\hline Comoros & 60 \\
\hline Bolivia & 60 \\
\hline Tajikistan & 60 \\
\hline Rwanda & 60 \\
\hline Guatemala & 56 \\
\hline Senegal & 54 \\
\hline Sao Tome and Principe & 54 \\
\hline Afghanistan & 53 \\
\hline Malawi & 53 \\
\hline Honduras & 51 \\
\hline Madagascar & 50 \\
\hline Kenya & 50 \\
\hline South Africa & 50 \\
\hline Eritrea & 50 \\
\hline & \\
\hline
\end{tabular}

Source: CIA, World Fact Book, January 2008

In Table 7, it can be seen that countries with literacy rate below $60 \%$ are mostly African, Latin American and South Asian countries. 


\section{Proposal for Islamic Economic Framework}

Table 7: Countries with less than $60 \%$ literate people

\begin{tabular}{|l|c|c|c|c|c|c|c|}
\hline \multirow{2}{*}{ Country or area } & \multirow{2}{*}{ Year } & \multicolumn{3}{|c|}{ Adult (15+) literacy rate } & \multicolumn{2}{l|}{ Youth (15-24) literacy rate } \\
\hline & & Total & Men & Women & Total & Men & Women \\
\hline Afghanistan & 2000 & 28 & 43 & 13 & 34 & 51 & 18 \\
\hline Bangladesh & 2007 & 53 & 59 & 48 & 72 & 71 & 73 \\
\hline Benin & 2007 & 41 & 53 & 28 & 52 & 63 & 41 \\
\hline Bhutan & 2007 & 56 & 67 & 42 & 78 & 83 & 73 \\
\hline Burkina Faso & 2007 & 29 & 37 & 22 & 39 & 47 & 33 \\
\hline Burundi & 2000 & 59 & 67 & 52 & 73 & 77 & 70 \\
\hline Central African & 2000 & 49 & 65 & 33 & 59 & 70 & 47 \\
\hline Republic & 2000 & 26 & 41 & 13 & 38 & 56 & 23 \\
\hline Chad & 2000 & 49 & 61 & 39 & 61 & 71 & 52 \\
\hline Eôte d'Ivoire & 2004 & 36 & 50 & 23 & 50 & 62 & 39 \\
\hline Guinea & 2003 & 29 & 43 & 18 & 47 & 59 & 34 \\
\hline Liberia & 2007 & 56 & 60 & 51 & 72 & 68 & 76 \\
\hline Mali & 2007 & 23 & 31 & 16 & 29 & 36 & 23 \\
\hline Mauritania & 2007 & 56 & 63 & 48 & 66 & 70 & 62 \\
\hline Morocco & 2007 & 56 & 69 & 43 & 75 & 84 & 67 \\
\hline Mozambique & 2007 & 44 & 57 & 33 & 53 & 58 & 47 \\
\hline Nepal & 2007 & 57 & 70 & 44 & 79 & 85 & 73 \\
\hline Niger & 2007 & 30 & 44 & 16 & 39 & 53 & 26 \\
\hline Pakistan & 2007 & 55 & 69 & 40 & 70 & 79 & 60 \\
\hline Papua New Guinea & 2007 & 58 & 62 & 53 & 64 & 63 & 65 \\
\hline Senegal & 2007 & 43 & 53 & 32 & 51 & 59 & 44 \\
\hline Sierra Leone & 2007 & 38 & 50 & 27 & 54 & 64 & 44 \\
\hline Togo & 2000 & 53 & 69 & 38 & 74 & 84 & 64 \\
\hline Yemen & 2007 & 59 & 77 & 40 & 80 & 93 & 67 \\
\hline & & & & & & & \\
\hline
\end{tabular}

Source: United Nations Statistics Division

As mentioned above, attainment to education has also become a function of one's income. In Egypt, school attendance of the poorest 20 percent of the population lags from 30 to 45 percentage points behind that of the richest. 


\section{Proposal for Islamic Economic Framework}

Figure 4 a): Share of 15- 19-year-olds completing each grade or higher in Egypt in 2000 , by family wealth quintile (\%)

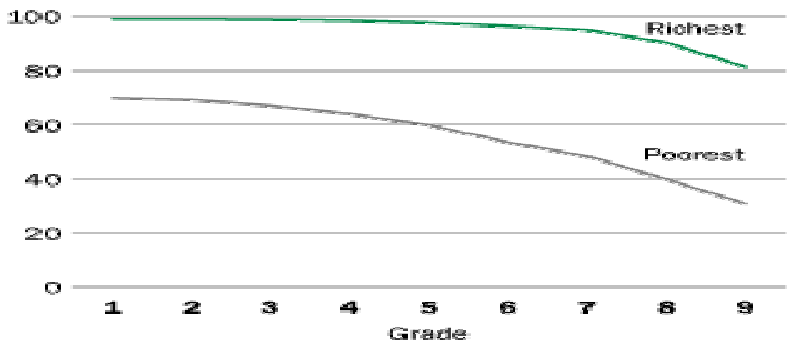

Source: World Bank staff estimates.

In India, most children from rich families enroll and stay in school. But, many poor children never enroll, and those who do, stay for only a few years.

Figure 4 b): Share of 15- 19-year-olds completing each grade or higher in India in 199899 , by family wealth quintile (\%)

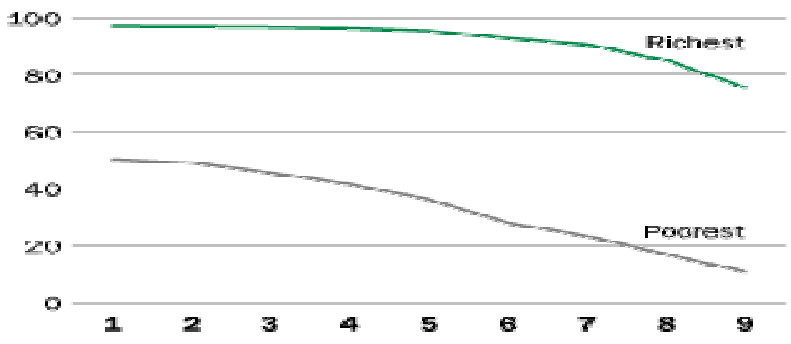

Source: World Bank staff estimates.

In a poor country, children from the richest families may not attend primary school. In Niger, few children, rich or poor, stay in school past primary stage.

Figure $4 \mathrm{c}$ ): Share of 15-19-year-olds completing each grade or higher in Niger in 1998, by family wealth quintile (\%)

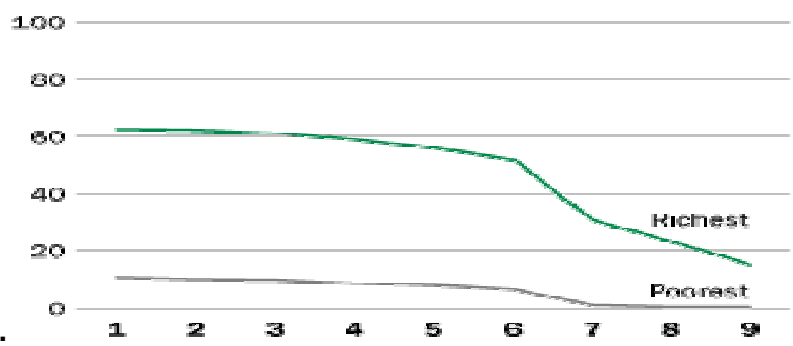

Source: World Bank staff estimates. 
Enrolling all children in school is the starting point. Keeping them in school is the next step. In Peru, many children from poor families soon leave school.

Figure 4 d): Share of 15- 19-year-olds completing each grade or higher in Peru in 2000, by family wealth quintile (\%)

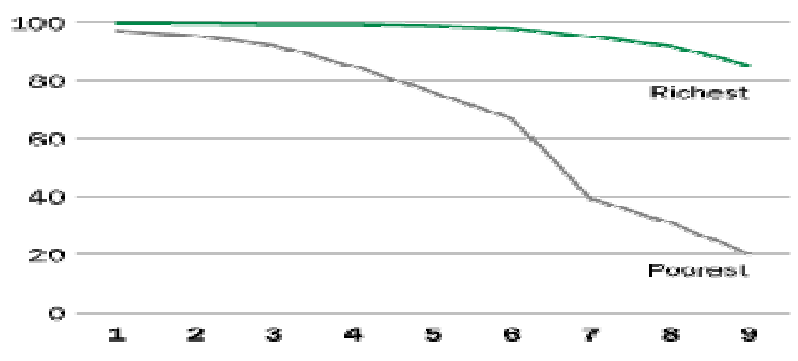

Source: World Bank staff estimates.

Just like education, access to better health conditions has also become a function of one's income. Women are most in need of skilled care during and immediately after delivery, when most maternal deaths occur. About half the births in developing countries are not assisted by a skilled health worker.

Figure 5: Ratio of female to male HIV rates, ages 15-24, 2001

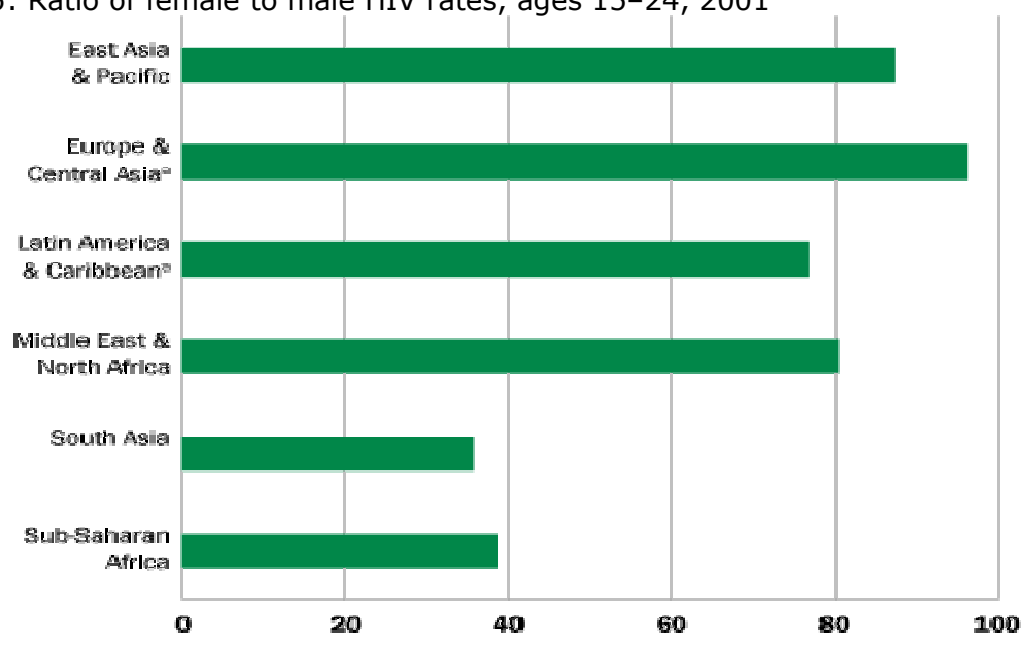

Source: World Bank staff estimates.

AIDS is an increasing cause of death in young children, but it is also leaving millions of children orphaned. By the end of 2003, 15 million children worldwide, 12 million in Sub-Saharan Africa, had lost one or both parents to AIDS.

In Sub-Saharan Africa, where the epidemic is most widespread, the number of children who have lost both parents is increasing rapidly. These children are 
particularly vulnerable to disease and neglect, creating an unprecedented social problem.

Figure 6: Children losing both parents (millions)

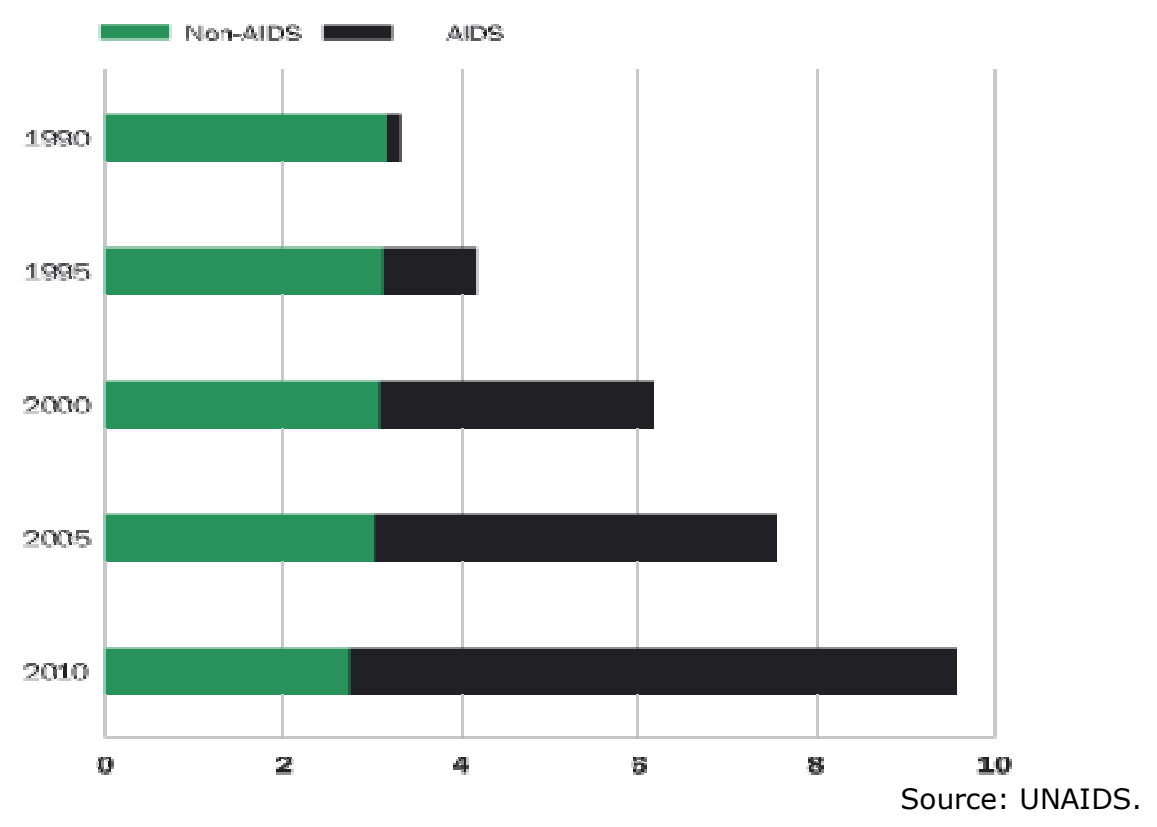

Coming out of a debt and poverty trap requires consistent growth for a sustainable period. But, international trade restrictions take much of the ability to grow from developing countries. Tariffs charged by high-income countries on goods important to developing countries, such as textiles and agricultural products, remain high. Subsidies of $\$ 350$ billion a year to agricultural producers in OECD countries are another barrier to developing country exports. Global trade is not yet a level playing field.

Figure 7: Average Tariffs by High-Income countries on developing country imports (\%)

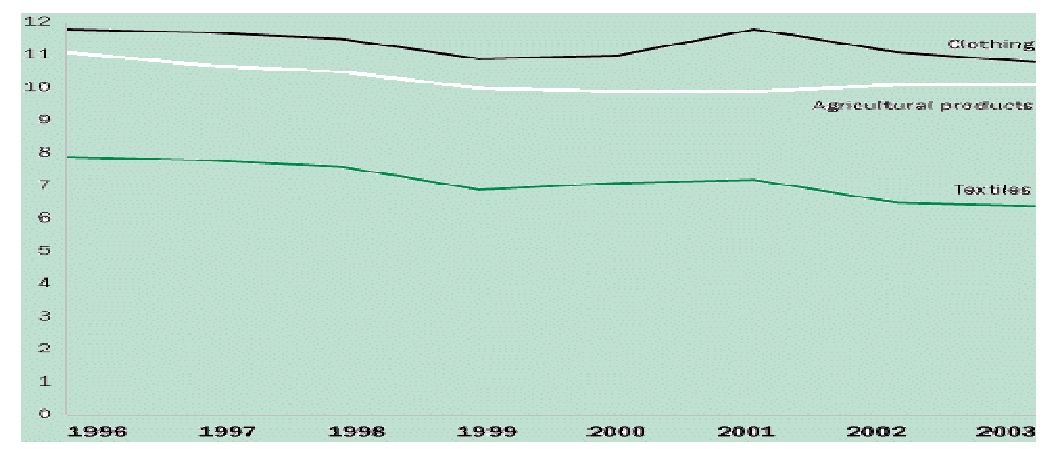

Source: International Trade Centre, World Trade Organization, and United Nations Conference on Trade and Development. 
Other than tariffs, high-income countries accuse developing countries of not following environmental standards, TBT, SBT etc and thereby further reduce the ability and capacity of developing countries to gain from exchange and get out of debt and poverty trap. In Figure 8, it is shown that high-income countries account for half the world's $\mathrm{Co}_{2}$ emissions

Figure 8: High-income countries account for half the world's $\mathrm{CO}_{2}$ emissions

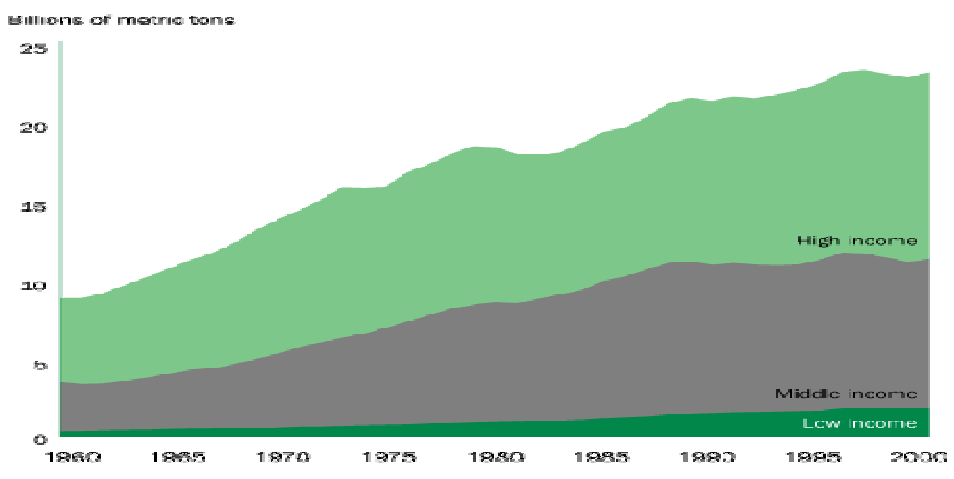

Source: Carbon Dioxyde Information Analysis Center data

In Figure 9, it is shown that high-income countries account for $36 \%$ of emissions of organic water pollution.

Emigsions of organic water polutants, 1998

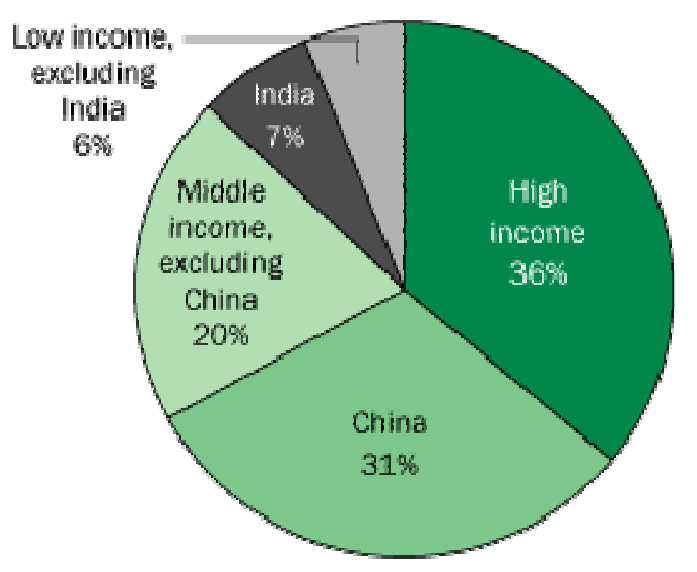

Source: World Bank staff estimates.

Due to this, most developing countries are going through a perpetual debt trap which takes away resources that could have been used on development, but instead are used to service compounded debt. In figure 10, it is shown that interest payments take up most of the resources of the government. It must be kept in mind that principal amount of debt remains same even if debt is serviced 
each year. Even if only debt is serviced each year, the debt servicing amount would continue to increase each year with compounding effect.

Figure 10: Interest expense as a \% of total government's expense

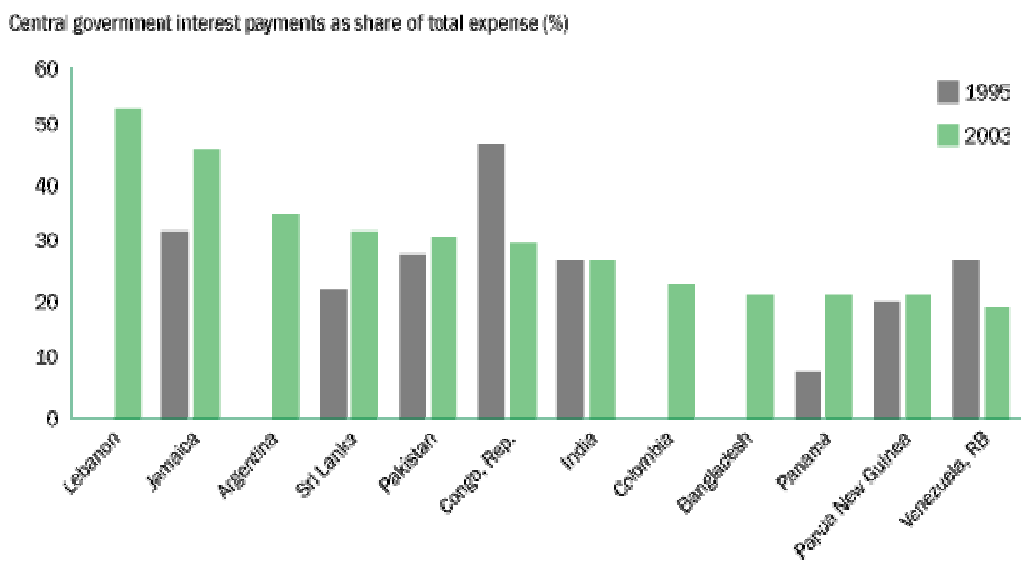

Note: Deta for 2003 refer to the most recent year forwhich data are availatle in 2001-03. No dato are aralable for Lebarm, Argentim, Colombla, and Bangadesh for 1995.

Source: Intemational Monatary Fund, Gowemment Finance Statisties dala files.

World's total expenditure on Military stands at \$1.46 Trillion. USA accounts for $41.5 \%$ of world's total military expenditure (Source: Stockholm International Peace Research Institute Yearbook 2009).

It would be interesting to see where the poor of the world are. As is shown in figure 11, most of the poor are living in Asia, Africa and Latin America. These three continents are the most populous continents of the world.

Figure 11: World Poverty Map by Continents

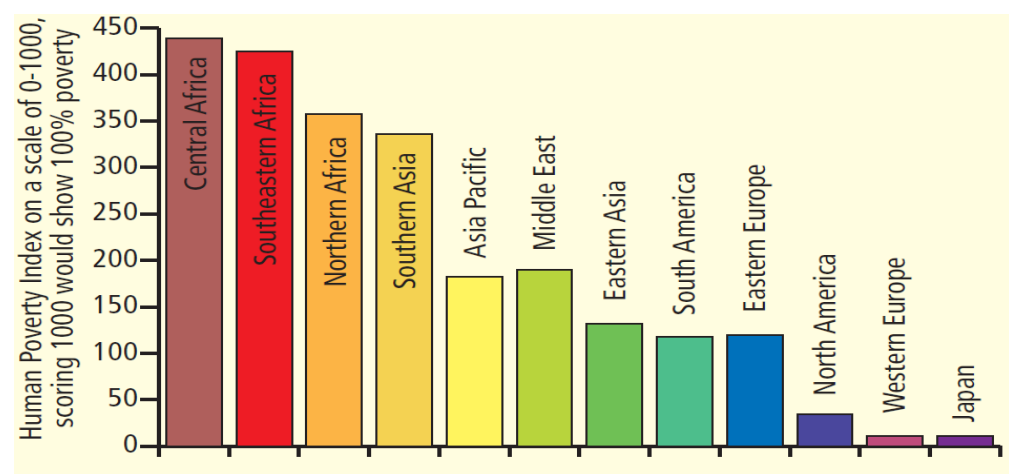

Source: UNDP 2004 Human Development Report 
Figure 12: World Poverty Map

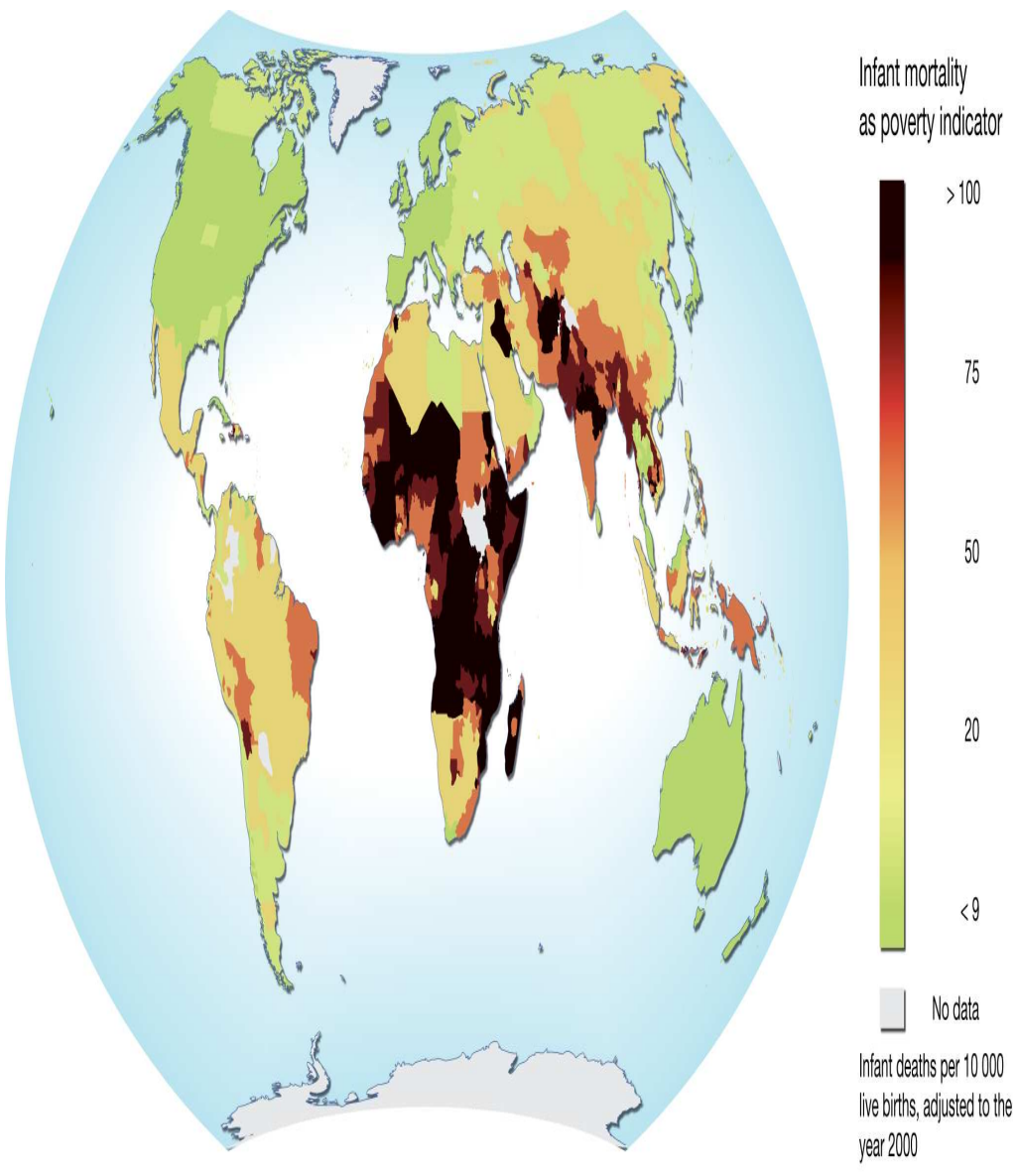

Source: CIESN 2005

As we can see in Figure 12 as well, most of the world's poor reside in Africa, Latin America, South Asia and Central Asia. 


\section{Challenge of Economic Development in Pakistan}

\section{Poverty}

Pakistan saw decrease in poverty levels in later part of 90 s and until at least by 2005 when the economy experienced a boom after 9/11. But, in the aftermath of the economic meltdown, poverty has started to increase again as poor people have lost jobs and those who have retained their jobs have not been getting increase in their real wages. Increase in wages is not proportionately equal to the increase in inflation.

In Pakistan, at least $25 \%$ of the people live below the line of poverty. Hence, one fourth of the population is not even able to get subsistence standard of living. Poverty is not just a standalone problem; it is a mother of many problems.

Poor people are deprived of clean drinking water, adequate sanitation, and affordable medical facilities and therefore, they have malnourished children, infant deaths and plethora of other diseases to bear with.

Poor people are also not able to get adequate education. Even if free education is provided to them, their opportunity cost of not sending their child to work is usually greater than the cash subsidy provided to them for education and leaving work. Therefore, the children of poor families remain uneducated and then it becomes extremely difficult for them to get out of the poverty trap.

\section{Inequality}

In Pakistan, there is significant income inequality. Income inequality results in social stratification. This stratification affects social relations like marriages and economic relations in the form of nepotism. Cartels are also a reason why most industries remain oligopolistic. Many industrialists form conglomerates especially having stakes in complimentary industries. Consolidation in industries beyond a certain level brings market imperfections inevitably.

The dearth of documentation and security/collateral deprives poor people of official and formal sources of financing. Hence, poor people use informal sources of financing paying higher interest rates and if they default, they often become subjects to their lenders and have to submit themselves and their siblings after them to bonded labor. It makes it very difficult for them to get out of the debt trap.

Access to quality education also becomes a function of one's level of income. Therefore, income inequality also results in unequal access to quality education. In most developing countries, developed expenditure is almost always contingent on the loans and grants obtained. Therefore, state patronage of developing SME financing and micro financing remains an issue given low priority. 


\section{Proposal for Islamic Economic Framework}

\section{Unemployment}

Unemployment is also another big problem Pakistan is facing in recent years. Even if unemployment has decreased a bit in last 5 years, it has created many other problems. Employment generation has taken place mostly for educated people. Employment generation for poor and uneducated has increased mostly in urban areas. It has resulted in huge migration from rural areas to urban areas. This massive migration in last 10 years from rural areas to urban areas hasn't been complemented by the same increase and development in infrastructure. Therefore, it has resulted in increase in cost of real estate in urban areas, power shortage, pollution and even crimes.

Furthermore, after WTO implementation, textile and other sectors of Pakistan have been exposed to the global competition and domestic producers are finding it very difficult to be competitive as government is also short of funds and cannot provide incessant subsidies to the ailing industries. Therefore, this has and unfortunately may further result in more layoffs and unemployment in the times to come.

\section{A Brief Introduction to the Contents of the Book}

This book provides a holistic socio-economic framework working in conformity with the Islamic principles. Chapter 2 builds the ground for the proposed framework by discussing the foundations of the ethical precepts of Islam. It discusses the thesis of religion, answers some of the questions in the comparative study of religion and tries to resolve few of the misconceptions about the faith of Islam.

Chapter 3 outlines the economic teachings of Islam with regard to earning and spending. It discusses at length the ideals Islam set before its adherents in the ethical sphere of life. The ethical principles are discussed based on the study of relevant Quranic text and the narrations of Prophet Muhammad (PBUH).

Chapter 4 studies the comparative economic systems. It analyzes Capitalism, Socialism, Mixed Economy and Islamic economic system. Chapter 5 introduces the salient features of the proposed economic framework with special focus on fiscal reforms. It discusses the potential of the institution of Zakat to meet fiscal needs of the government and to assist it in doing away with deficit financing, fiscal bleeding, crowding out private sector and reducing deadweight loss by parting the way with private sector so as to ensure market economy operating on its own as far as possible and playing an active regulatory role.

Chapter 6 introduces the monetary reforms. It discusses how savings would feature despite discontinuation of interest, how inflation will be checked with central banks not having at their disposal conventional $\mathrm{OMO}$, how liquidity will be managed in banking sector when a central bank wants to inject liquidity or mop up funds. How and to what extent the institution of Zakat would enable the government to meet its fiscal targets and does not crowd out private sector with public borrowing. How balance of payments and exchange rate stability can be 


\section{Proposal for Islamic Economic Framework}

managed in an interest free economy. If in the short term, the government or central bank needs alternative source of revenue other than Zakat, they can issue GDP linked bonds. This could replace T-bill and provide a base instrument for $\mathrm{OMO}$ and liquidity management in the banking and financial sector.

Chapter 7 introduces the currently practiced Islamic Banking and Finance. Since Islamic economic principles have more prominently been used in banking and finance, much of the discussion centers on Islamic banking and finance in lieu of analyzing the existing practices and then in the next chapter, preferable alternatives in areas where shortcoming is observed and need for improvement is felt are suggested.

Chapter 8 discusses the financial system in the proposed framework with the role of institutions and the discussion on comprehensive need fulfillment mechanisms to serve every major need of a sophisticated contemporary financial system.

Some important novel changes are recommended, such as introduction of options ${ }^{1}$ in mortgage financing, which will allow the bank to separate the tenancy and sale contract in a distinctive way. This will still ensure that it locks the sale with the borrower or with the third party without making both contracts dependent on each other. It will benefit the bank as well as the borrower, who will have an option but not an obligation to buy the asset at maturity.

The modified role of bank entering in a Mudarabah ${ }^{2}$ contract as a "Rabb-ul-maal" (investor) will ensure that the bank takes on operational risk. It will enable the resources to go into productive avenues rather than in financial instruments. This modification will generate employment and productive activities in the economy in a more direct manner.

The division of Mudarabah corporate and Mudarabah consumer will target two very distinct markets and will result in channeling of funds from saving surplus units to saving-deficient units. Reforms in equity markets and alternatives for insurance are also suggested.

Chapter 9 introduces feasibility and structure of Micro credit as an alternative for interest based micro finance. It discusses how the potential obstacles in the form of lack of trust, funding commitment, lack of collateral arrangement, lack of documentation etc would be handled.

\footnotetext{
${ }^{1}$ It gives the right to option holder to exercise his right to buy (call) or sell (put) at an agreed excercise price on or before exercise date.

${ }^{2}$ Mudarabah is a form of partnership in which one partner invests with capital and one with labor.
} 


\section{Chapter 2}

\section{THESIS OF RELIGION}




\section{Proposal for Islamic Economic Framework}

Morality is very eloquently discussed by Kant (1889/1785). He said that intentions define actions and not the consequences and not even compassion. He said it because compassion is temporary, a particular state and is not absolute. However, intentions best define the existence of morality in actions.

But, Kant did not give the method by which we could prioritize Maxims. For instance, truth and justice both are important moral values. But, what should we do if there is a conflict between the two? For illustration, if a murderer is known to us as murderer, but if we do not have witnesses to prove him as murderer in the court of law, should we give false testimony to convict him?

Islam helps us to prioritize Maxims. Islam shows us that this world is not fair in all respects. A morally upright man is not necessarily the most honorable man in the world. A morally upright trader is not necessarily the richest in the world. Not all murderers have been or will be convicted in this world. Even if all murderers were convicted, it will not be 'naturally' possible to give equitable punishment to the murderers who have killed more than one human being.

Even if it was possible, it will not be possible to reverse the immoral actions. What happened has happened and cannot be reversed. Death is the plainest truth and if justice cannot be provided in the life of a person and that being too not equitable; then, is it not rational if we believe in life after death where everyone would be given equal rewards and equal punishment for his acts and God by his infinite wisdom would be able to judge without any doubt the intentions behind the actions and justice will be provided to each and every one?

Furthermore, only with the knowledge of life after death and the belief in God, can one decide to act morally as an end in itself and not merely as means to a material end. Moral act in Islam also is a means to an end i.e. to achieve eternal success and blessings of God. But, it is not a material end confined to this life only. In this way, the utilitarian mind is also satisfied as happiness is a relative term not achieved only by material things. The fact that moral actions even if they are not rewarded in this world will be rewarded in life hereafter satisfies the utilitarian mind.

We know what is right and what is wrong through our conscience. In matters where our conscience does not guide us, God intervenes and guides us through His prophets. Therefore, Prophets guide us in matters where we might not have reached the right decision about right and wrong through our conscience, for instance, interest, gambling, liquor etc. They might seem useful and right. But, God tells us in Holy Quran that there is more harm in these things than good.

Today, we are seeing interest based system and gambling (speculative financial instruments) causing severe disorder in the economy. Similarly, the greatest asset of a human is his power to reason, his intellect, his use of wisdom and his ability to think. When we take liquor, we lose our greatest asset i.e. conscience and often do bad things which harm others also, besides us. For instance, we 


\section{Proposal for Islamic Economic Framework}

see people having accidents, people misbehaving with other women after taking liquor etc.

If one believes in this life only; then, he will be more selfish as he would like to get everything in this life. If we restrict our existence confined to this world alone with no accountability in afterlife; then, I am "just" as long as I am "just" in front of the society even though there could be sins that society never saw me doing. I am "unjust" in front of the society since it saw me convicted based on an evidence which in itself was untrue. Life hereafter gives all our actions the meaning by giving each and every soul the equal reward and punishment.

People can take justice in their own hands if they are allowed absolute freedom. So, we need institutions that will impose certain restrictions on all of us so that we can enjoy our freedom without denying anyone else's.

Islam is also such an institution which though puts restrictions on one's absolute freedom (as do all other systems), but Islam not only safeguards the rights of the people, but, more importantly and fundamentally, gives meaning to the life and our own existence.

We can use both reason and experience to believe in God. By way of reasoning, if we are creatures, then we are created by someone and that creator is God. The question that who created God is not valid as God is the creator and not the creature. Ultimate Creator needs not be created.

By way of experience, we can use empirical knowledge obtained from science to learn how the galaxies, planets, stars, rotation of the moon, rotation of the sun, rotation of the earth around sun, millions of living beings sustaining themselves in a universe that is so perfect by its design that even a tiny unusual interference can make life impossible on this earth, but it does not happen and it continues to exist. All this cannot be possible without it being created and managed by a single God. If there was more than one God, then there would not have been such 'uniformity' in the way we see universe and the way our planet earth works.

Furthermore, no meaning to life, world, man, his role and purpose can be explained without believing in God. Islam explains this by outlining our role as being created by Allah and being sent in this world to be judged for our actions and will be rewarded in life hereafter if we follow the teachings of God which principally mean to be just, kind, truthful, faithful, obedient and morally upright.

The fundamental value is freedom. Happiness results from it. Justice comes in to protect it. Men, we see become unjust using that freedom as speculated by Angels as well. Can we provide justice, happiness in a paradigm of absolute freedom? Even when men have little freedom in this world, we have seen them becoming unjust and then depriving the mission of providing maximum collective happiness for all. 


\section{Proposal for Islamic Economic Framework}

The fundamental question is that can we provide perfect justice in this world. Can we have maximum happiness as we envision in this world. Are we or can we be absolutely free in this world?

What is of fundamental importance is the fact that this test has to be 'just'. According to Islam, everyone would be judged based on his intentions, general attitude, general behavior, and general tendencies and most importantly in matters in which one has choice clarifies that this test is just.

How can a creation like this universe, having millions of stars, reachable not within centuries even at the speed of light, all so perfectly interwoven to make life exist and that too for some time as we do not grow to be immortal by way of evolution, be explained? Not only us, none of the species can escape from natural constraints and become immortal.

Everything in this world has been created in pairs. If there is thirst, there is water. If there is moon, it needs a sun to have its light reach us. If there is man, then there is a woman. Each one alone cannot live in isolation. They are all interdependent. Similarly, this world is incomplete without a belief in life hereafter.

This world alone shows that few people get good they do not deserve, few people do not get any good when they deserve more, some go through severe illness, some live a very healthy life, some are unjust and yet they are not given punishment, some are honest and they do not get rewarded. All these incomplete events suddenly end when we die. Then, if no one will get equitable reward and punishment, then there will be no reason why they should wait for an afterlife. They can do all the evils if they can avoid the law. But, even if they can, they do not always do that, they have the ability to differentiate between right and wrong inbuilt into their souls. They would like to do good and avoid bad.

Are we our own creators? Millions of species cannot just exist in such beautiful contrast without there being someone responsible for it.

For someone to be an ultimate creator, the Supreme Being, He has to be someone beyond the constraint of this world and nature. If the premise is that God created everything and nothing exist independent of His will. Then, logical conclusion would be that This Supreme Being, God, has to be an independent personality having no constraints of nature. This is a logically consistent view.

If God is powerful in one thing and not in other, then $\mathrm{He}$ is not a supreme being. If God is omnipotent, then humans cannot predict the behavior of God using examples of themselves because their frame of reference is limited and they are creatures and not ultimate creators and they have constraints.

The question arises, if God is omnipotent, can He be unjust. The God knows everything, but it has nothing to do with us having a freedom to choose our way. A teacher sometimes knows the fate of the students, but it is the student who 


\section{Proposal for Islamic Economic Framework}

makes his destiny provided the teacher is just. God's knowledge about a person has nothing to do with the trial in question. I can, by way of my expertise, predict the result of a cricket match, but it was not me who decided the result of the cricket match in the end.

If someone is my teacher, he has the power to fail me for no reason. But, if he is just, he will do justice and will not fail me; however, it does not mean that he could not do so because of his inability, but it is because he can not contradict his own attributes and values if he was consistent (as God is).

God is just as it will only hold us accountable for our actions in which we had choice. We will not be held accountable for color, race, creed etc. Therefore, everyone has an equal chance to succeed in life hereafter.

Religion provides the answer that this universe was created by a supreme being who created it for a purpose. Science also confirms that because it has not at all provided answers to "Why it is". Infact, science has shown that life cannot mathematically and statistically exist by chance. It is like saying that if you throw alphabets in the air, there is a slight chance that it would come down to the earth and become one of Shakespeare's poem.

It is not like that we humans have just come to this world today and are now looking for answers. We have history behind us that tells that the Prophets came with the message of God and the nations which were "direct recipients" who disbelieved were punished in this world. Christians, Muslims and Jews, all believe in that history and it is our common heritage.

Shops, factories, computer programs, machines etc, are systems and they run and are operated by someone. Universe is also a system and is the most complex and a grand system. How can it just be 'the only system' that does not require a creator. All the systems mentioned above have some purpose. How can only this most grand system have no purpose?

Why is there present so much contrast in species? Why not some species just by way of chance found nothing that they could eat? Found to have body structure that is suitable in land, but they exist in sea or vice versa. The limited knowledge we have about each and every living thing and how they live and exist is just fascinating.

How could all species exist in circumstances which suit them with respect to geography, climate, body structure etc? Why then still they die and not evolve into immortality. We could not do it. None of the millions of species could do it. The extinction of species and our death signifies that someone who created us (humans) and took our lives will indeed be able to bring us to life again and that life would justify the purpose of existence and give meaning to this worldly existence. 


\section{Proposal for Islamic Economic Framework}

Why none of the species became selfish enough to evolve differently so as to become a little bit superior to others etc. They would want to if they were all different kind of animals because we as animals (if we take the evolutionists' stance) know that we are selfish to some extent, and want freedom from natural constraints.

If humans were little smarter animals, then they would have at least made some progress to get out of the natural constraints and succeed in a millions of years of history of evolution that evolutionists support.

If I am standing aside to another person and if I am hit with a stick, why would only I feel the stick and not the other person? If we cannot sense each other, cannot get through our independent existence (considering we are the same types of animals), how can distinct species, one existing and one not existing, make way for each other in such a magnificent and perfect way in every detail that life becomes possible without there being a ultimate creator?

Can we avoid the question 'why' in any other matter of life? If we think that evolution defines a why or even if does not define it, it defines the material dispensation in this world and the human struggle and evolution in this world intellectually and physically, then we ought to believe that all the bodies of knowledge are also one way or the other biological processes.

How do we differentiate between right and wrong? It has not gone through any evolution. Speaking truth is considered (I am not saying acted upon) a right thing throughout history.

If we are not creatures, just a manifestation of nature, then, there needs to be no way to believe anything right or anything wrong, if we will just die without being accountable for our actions, then, if we can avoid the court of law, we can kill, steal, hurt, rape etc as long as no one can hold us accountable. But, we do not think and act like that. It is because we have conscience, ability to differentiate between right and wrong. Then, we have feelings and values, and in most cases, absolute feelings and values.

It makes this belief and argument very weak that this world and universe came out just other than by way of a creator creating it. Just like everything is created by a creator as we see it and observe it, this world and universe also has to be created.

It would be normal to believe like that as it will make us consistent. But, believing that every small thing, though insignificant, needs to be created by someone, but this universe came out naturally, species co-exist naturally, fulfill their needs naturally and all of a sudden die. What for?

A biological process cannot describe this complex set of choices we make through our conscience to uniformly identify right from wrong without being dependent upon any process or going through evolution 
If we restrict the scope of evolution to some aspects; then, it cannot claim to take a place of religion which is a set of comprehensive doctrine i.e. a holistic system of beliefs and practices. If evolution is restricted in just describing how, then any description of 'how' (either correct or incorrect) does not in principle contradict with the thesis of religion. One cannot avoid the question 'why' though.

Social learning theory can also not provide the wholesome answer because social learning requires for its acceptance and relevance a history behind some of the values which gradually need to become sacred so that the society could force it on others to believe it. In the start of life, nothing could be described as such.

Birds fly in winter to avoid cold. They have built-in map and take the best route to avoid flying over sea for most time. Birds few days old doing it for the first time in life without access to books, journals and experience can never do that as perfectly as they do neither by way of evolution nor by way of social learning. The process, any process, may it be evolution or a sudden big bang, or whatever, does not give any answer to 'why'.

A question arises as to why we cannot just able to see God and avoid having to solve this puzzle. We cannot see God, because God has sent us here for a purpose. That purpose would be meaningless if we could see God through our own eyes. But, we can observe, learn within ourselves and using our intellect to search for God and we will find the answer, but we have to be moral and unbiased in our search.

\section{Evidence of Muhammad's Prophet Hood in Religious Scriptures}

As said earlier, Allah sent Prophets in this world who guided us and showed us the right path. Christians, Jews and Muslims all believe in this history and as I said, it is our common heritage. Muslims believe that Muhammad (PBUH) is the last of the prophets sent by Allah. Next, we discuss some evidence for that in religious scriptures of Christianity and Judaism.

Saleem (1995) from the study of Qur'an and Taurāt showed the evidence of Muhammad's (PBUH) Prophet Hood. Moses (PBUH) declared the arrival of Prophet Muhammad among the Ishmaelites in the following words:

"The Lord your God will raise up for you a prophet like me from among your brothers. You must listen to him... The Lord said to me: What they say is good. I will raise up from them a Prophet like you from among their brothers; I will put my words in his mouth, and he will tell everything I will command him. If anyone does not listen to my words that the Prophet speaks in my name, I myself will call him to account." (Deuteronomy, 18:15-19)

Jesus (PBUH) declared the arrival of Muhammad in the most clearest of words. 


\section{Proposal for Islamic Economic Framework}

"Jesus said to them: Have you never read in the scriptures that the stone the builders rejected has become the capstone; the Lord has done this and it is marvelous in our eyes. Therefore, I tell you that the kingdom of God will be taken away from you and given to a people who will produce its fruit. He who falls on this stone will be broken to pieces but on whom it falls will be crushed." (Matthew, $21: 42-44)$

"And I will ask the Father and He will give you another Counselor to be with you forever -- the Spirit of Truth." (John, 14:16-17)

"But the Counselor, the Holy Spirit the Father will send in my name will teach you all things and will remind you of everything I have said to you." (John, 14:26)

"I will not speak with you much longer, for the prince of this world is coming. He has no hold on me." (John, 14:30)

"But I tell you the truth: It is for your good that I am going away. Unless I go away the Counselor will not come to you; but if I go away, I will send him to you. When he comes, he will convict the world with regard to sin and righteousness and judgment; in regard to sin because men do not believe in me; in regard to righteousness because I am going to the Father, where you can see me no longer; and in regard to judgment because the prince of this world now stands condemned. I have much more to say to you, more than you can now bear. But when he, the Spirit of Truth comes, he will guide you into all truth. He will not speak on his own; he will speak only what he hears, and he will tell you what is yet to come." (John, 14:7-13)

\section{Where Abrahamic Religions Disagree?}

As discussed before, the sign of a Prophet coming from Ishmaelite with attributes similar to Moses (PBUH) was mentioned in Deuteronomy. Muslims believe in all prophets including Jesus (PBUH) and Moses (PBUH) and the books sent to them and to other prophets. Muhammad (PBUH) is the last of all the Prophets and His arrival was well documented in Torah and Injeel as mentioned above. The book sent to Prophet Muhammad (PBUH) has not gone through any adulteration and thus remains the most authentic text than the other books for divine guidance in a post Muhammad (PBUH) period. Jesus (PBUH) was a prophet of God, as per Islamic faith, He was neither God nor a son of God. He was sent as a messenger of God to remind people of their duty to follow the guidance of God and was not sent to take up sins of others and sacrifice His life for Adam's sin. Adam (PBUH) was forgiven upon repentance by God as told by Quran and as believed by Muslims.

Respectfully, a humble question I submit to the readers is that how can it be explained that a boy steals and is not punished and could not be forgiven either. After centuries, the judge considered all the siblings of that boy as sinners and committed suicide himself or sacrificed his son for that sin. This analogy is neither meant to disrespect any faith nor mentioned to lead to any conclusion. 


\section{Proposal for Islamic Economic Framework}

\section{Muhammad (PBUH) in the eyes of non-Muslims}

Now, when we have understood the basic premise of religion, it would be worthwhile to understand the character of Muhammad (PBUH) Who is the Best Role Model in the faith of Islam.

Writing on Muhammad's (PBUH) prophecy, Scott (, p.126) wrote:

"If the object of religion be the inculcation of morals, the diminution of evil, the promotion of human happiness, the expansion of the human intellect, if the performance of good works will avail in the great day when mankind shall be summoned to its final reckoning, it is neither irreverent nor unreasonable to admit that Muhammad was indeed an Apostle of God."

Describing His upright character and personality attributes, Muir (1912) wrote:

"If he turned in a conversation towards a friend, he turned not partially, but with his full face and his whole body. In shaking hands, he was not the first to withdraw his own; nor was he the first to break off in converse with a stranger, nor to turn away his ear. A patriarchal simplicity pervaded his life. His custom was to do everything for himself. If he gave alms, he would place it with his own hands in that of the petitioner. He aided his wives in their household duties, mended his clothes, tied up the goats, and even cobbled his sandals. His ordinary dress was of plain white cotton stuff, made like his neighbors'. He never reclined at meals. Muhammad, with his wives, lived, as we have seen, in a row of low and homely cottages built of unbaked bricks, the apartments separated by walls of palm branches rudely daubed with mud, while curtains of leather, or of black haircloth, supplied the place of doors and windows. He was to all of easy access...

... Muhammad displayed all the qualifications of an able and experienced ruler. What renders this more strange is that he was never known himself to write.

A remarkable feature was the urbanity and consideration with which Muhammad treated even the most insignificant of his followers. Modesty and kindliness, patience, self denial, and generosity, pervaded his conduct, and riveted the affections of all around him. He disliked saying No. If unable to answer a petitioner in the affirmative, he preferred silence. He was not known ever to refuse an invitation to the house even of the meanest, nor to decline a proffered present however small. He possessed the rare faculty of making each individual in a company think that he was the favored guest. If he met anyone rejoicing at success, he would seize him eagerly and cordially by the hand. With the bereaved and afflicted, he sympathized tenderly. Gentle and unbending towards little children, he would not disdain to accost a group of them at play with the salutation of peace. He shared his food, even in times of scarcity, with others, and was sedulously solicitous for the personal comfort of everyone about him. A kindly and benevolent disposition pervaded all those illustrations of his character. Muhammad was a faithful friend. He loved Abu Bakr with the close affection of a 
brother; Ali, with the fond partiality of a father. Zaid, the freedman, was so strongly attached by the kindness of the Prophet, that he preferred to remain at Makkah rather than return home with his own father. 'I will not leave thee,' he said, clinging to his patron, 'for thou hast been a father and mother to me."'

Leonard (1909, p. 09) describing the purity and of His message and mission wrote"

"If ever any man on this earth has found God; if ever any man has devoted his life for the sake of God with a pure and holy zeal then, without doubt, and most certainly that man was the Holy Prophet of Arabia."

\section{Some Misconceptions about the Faith of Islam}

History does not give us a regular pattern of human struggle towards a just and fair political, social and economic setup as described by Hegel and Marx in their discussion on historical epochs i.e. historical materialism. Kant also did not tell when we will be able to say that we are living in an enlightened age. These views of Marx and Kant were more relevant to Europe only. Muslim world provided a socially, economically and politically just system to the world for at least 50 years in the rule of Caliphates. Religion during that time complimented justice, fairness, development and tolerance in the society as against the Marx's view that religion is opium.

However, one clear difference has to be appreciated between Muslims and Islam. Most of the laws in Christianity were mainly developed by humans themselves like St. Paul. Therefore, when thinkers of 15th century and afterwards criticized the church and the clergy, their criticism was also on religion and it was justified as the Christianity and the Clergy were the one and the same thing.

Islam is the message of God as was Christianity with the difference that the divinity of Christianity was obscured and later modified by Christians. Islam as a message of God remained pure. However, Muslims as all other human beings have not been and are not perfect in their acts and systems. But, the acts of Muslims cannot be regarded as representative of what Islam is as Islam was not invented by Muslims.

Therefore, a distinction has to be made between the Muslims and Islam. Muslims may or may not be acting truly on Islam and hence their actions do not determine what Islam is. When we study the 'Pure Islam', we will find that there is nothing irrational or unjust in its philosophy and teachings.

In the following lines, some of the most controversial and misunderstood issues relating to Islam are briefly clarified: 


\section{Proposal for Islamic Economic Framework}

\section{Rights of Women in Islam}

As per Islam, Muslim women like men must educate themselves. They can own property and wealth. They have the right to choose their husbands and the right to separate from their husbands.

They are entitled to have 'Mehr' (wealth at the start of marriage), 'wirasat' (share in inheritance upon the death of husband, children and father etc). Islam does not make it obligatory on women to earn for their family. However, they can earn for the family and yet they are not obliged to spend their earnings on the family. They have a right to choose an occupation and earn their livelihood. However, men are obliged to spend their earnings on the family and they are made primarily responsible for earning the livelihood for their children and wives.

As per the Hadith of Prophet Muhammad (PBUH), a mother must be respected three times more than the father by the children. A husband is not a man in isolation; he is also a son of his mother and must obey and respect his mother.

No man is allowed to have extra-marital relationships with other women. Adultery is a severe crime in Islam. People who have indulged in adultery cease to have a right to marry a chaste partner in a Muslim society. Rapists are recommended for capital punishment in Islam.

\section{Rights of Non-Muslims in Islam}

Non-Muslims can worship at their worship places. Government is responsible to safeguard their worship places. No non-Muslim can be forcibly converted to Islam. Muslims believe in all Prophets sent by God including Ibrahim (PBUH), Moses (PBUH) and Christ (PBUH). Hence, people believing in other Prophets do not face the risk of blasphemy in Islam.

\section{Jihad in Islam}

Jihad i.e. to struggle is a broader term and is not limited to a specific meaning. Holy Quran says that Jihad (in the meaning of armed struggle) can only be for the sake of eliminating injustice [Al Hajj: 39]. It is not a fight against non-Muslims. It is fight against injustice. It can only be undertaken as a last resort to eliminating injustice. It can only be undertaken by the government and not by the community on its own.

In all great battles of Badr, Uhud, Ihzab etc., Muslims in the leadership of Prophet Muhammad (P.B.U.H) fought a defensive war as the war was imposed upon Muslims.

Jihad cannot be undertaken for the expansion of the state, against innocents, against non-combatants, against the contract of peace if it has been signed and it 
cannot be sudden and unannounced. So, suicide bombing against civilians is out rightly unislamic.

\section{Islamic Concept of Equality}

All men are equal. No white has superiority over a black. Only Piety and Righteousness are the attributes that will distinguish us before God in life hereafter [Al-Hujurat: 13]. No rich has superiority over a poor.

All men should have equal chance to earn their livelihood. Interest which results in concentration of wealth is prohibited in Islam. No discrimination is permitted based on ethnic, religious, racial or gender basis in all walks of life.

\section{Does Islam have Bloody Borders?}

Huntington (1997) raised the debate of clash of civilizations and argued that Islam has bloody borders. But, the figure below paints a very different picture and confirms that almost all major countries in the race to expend on military are not Muslim countries.

Figure 13: Global Distribution of Military Expenditure

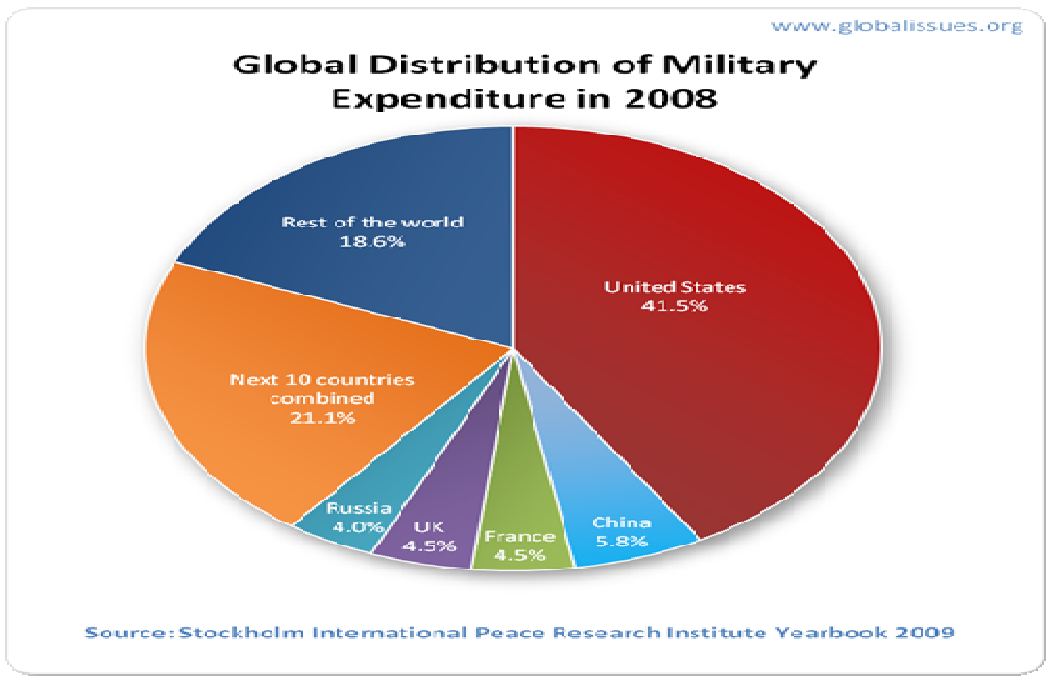

It must be clarified once again that Muslim history does not determine what Islam is. The message of Islam comes from the Holy Quran and the Way of Prophet Muhammad (PBUH). For this reason, Huntington may classify Democracy as an exclusive feature of western civilization. However, Islam, instead of discouraging democracy, directed Muslims to instigate democracy as a recurrent process and guiding principle for collective decision making in their systems [Al-Shura: 38]. 
Furthermore, Islam directs Muslims to uphold justice and directs that even enmity of a nation must not digress them from the path of justice. [AI-Maida: 8].

Injustice is one of the main hurdles in bringing about peace. Injustice in politics, in economics and in every sphere of life must be avoided as per Islam. Islam favors democracy, though it does not permit Secularism. Maulana Maududi (1984) analyzing the consultative decision making principle in Islam as taken from the Holy Quran [Al-Shura: 38] deduced that democracy as a principle of decision making is not alien to Islam; rather it is most desirable as per the Islamic principles.

Secularism as a philosophy or comprehensive doctrine is not entirely democratic and does not allow religion to prevail in public sphere of life even if democracy allows it. It confines religion to one's private life only and does not permit democracy to allow religion to expand into the public sphere of life. Hence, Islam favors democracy yet it also permits individual freedom in choice and practice of one's religion or comprehensive doctrine unlike in France and Turkey who claim to be secular and yet depriving Muslims and people from other religions to practice their religion and uphold their values and culture symbols. 


\section{Chapter 3}

\section{ISLAMIC ECONOMIC TEACHINGS}




\section{Islamic Economic Teachings}

Now, when we have understood the basic thesis of religion, we can embark upon discussing the economic teachings of Islam more specifically.

\section{Sovereignty of God}

The fundamental philosophy of Islam is based on this concept that all powers belong to God. All the authority rests with one and only God. We must only worship Him. We must follow His guidance to succeed in the life hereafter.

\section{A Man's Purpose of Existence}

The purpose of man's existence as defined by Quran is:

"We have created you so as to judge who among you are the best followers of our words." [Al-Mulk: 2]

\section{Scope of Life}

A Muslim's scope of life should be broader. His principal goal should be to seek God's pleasure and succeed in the life hereafter.2 So; he is supposed to make every decision in a way to seek God's pleasure.

\section{Islamic \& Capitalism Philosophy}

Chapra (2003) viewed secular societies continuing to belittle the need for moral development; though all of them now profess commitment to development with justice. He emphasized that even material development with justice is not possible without moral development. The rationale for this contention is that development with justice requires an 'efficient' and equitable use of all resources and both 'efficiency' and 'equity' can neither be defined nor actualized without the injection of a moral dimension into economic pursuits. In post modernism literature, Marcuse (1964) has described this phenomenon as 'One Dimensional Man' in his book with the same title.

\section{Islamic Model}

Scarce Resources

Seeking God's pleasure

Unlimited Wants

Differentiate between right and wrong

\section{Capitalism Model}

Scarce Resources

Seeking self benefit

Neutral between right and wrong Unlimited Wants 
Difference between Interest and Profit

\begin{tabular}{|l|l|}
\hline \multicolumn{1}{|c|}{ Interest on Capital } & \multicolumn{1}{|c|}{ Profit on Trade } \\
\hline $\begin{array}{l}\text { Confirmed profit irrespective of the } \\
\text { result that lent money gives to } \\
\text { borrowers. }\end{array}$ & $\begin{array}{l}\text { Profit depends upon market } \\
\text { mechanism and is not a function of } \\
\text { money or investment. }\end{array}$ \\
\hline Continuous profit on lent money. & One time profit on any transaction. \\
\hline $\begin{array}{l}\text { Confirmed profit on taking no price \& } \\
\text { market risk. }\end{array}$ & $\begin{array}{l}\text { Profit/Loss on taking risks and putting } \\
\text { effort. }\end{array}$ \\
\hline
\end{tabular}

\section{How This System Works}

Suppose in an economy, there are two people, one blessed with a lot of capital and one with a very little. The one who has a little capital wants his living standard or financial status to improve. He thinks this way by looking at a luxurious lifestyle of that rich person. He goes to the rich person and asks him for capital. The rich person says, 'I will lend you Rs.120 and you will need to pay $10 \%$ interest per year on it.' Since the poor person does not have access to equity financing, the poor person agrees and the rich person lends him money.

After one year, he earns Rs.12, he goes to the rich person and begs for forgiving the interest, but the rich person doesn't agree and says that now the interest will be charged on $10 \%$ of the original amount plus the interest accrued $(120+12)$ i.e. Rs. 132. Now, one can clearly see what will happen next, the poor person will be at a higher risk for the next year. The greater the risk, the less he will think about right and wrong in his business dealings. He might survive but by bringing damage to the society and its values. The rich person has to worry about nothing. Whatever happens, he will be earning interest. His prospects of earning higher interest will grow as the severity of the needs of the people will increase.

\section{Capital Owner:}

Risk free investment (Rs. 120).

Confirmed $10 \%$ interest income.

\section{Borrower:}

Takes risk and puts in effort.

No Confirmed profit (Profit >12, Profit <12).

\section{Analysis of Logical Reasons to Favor Interest}

\section{Interest is the price of risk}

It is not right to say that lending money involves a risk. Because the lender gets interest in any condition, whereas businesses after taking risk either earn profit or incur a loss. 


\section{Proposal for Islamic Economic Framework}

\section{Price of self-forgone needs}

A lender lends a portion of his money that he doesn't need immediately. So, he is not forgoing his needs as his needs are already fulfilled. He is only lending the money that is in excess of his needs.

\section{Share in the profit of the borrower}

Interest is not a share in the profit of the borrower because if money is borrowed for fulfilling needs rather than for conducting business, then, there is no question of a profit. But, even if money is lent for commercial purposes, then, how can we say that the business will be profitable. Businesses earn profit and incur losses, why the investor doesn't share in the loss and what sort of an effort he has put in to demand a profit that is fixed and confirmed irrespective of the profitability of the business.

\section{$\underline{\text { Interest is a rent on money }}$}

Those things on which rent is charged are used and given back in the same existing condition like homes, cars etc. while money and other consumption goods are consumed. When we borrow money, we consume it and regenerate it. When the money is consumed, the borrower has to regenerate it and the lender without taking any risk is entitled to receive the consumed money with the interest. Can we borrow apples or mangoes on rent? We can borrow hammer but not the nails based on the above classification.

Riba is a technical term in Islamic Shariah. It refers to 'Anything paid/charged over and above the principal amount on a loan'. It is an undisputed and agreed upon definition of Riba and is backed up by the consensus of all Islamic scholars and schools of jurisprudence. It is used in this specific sense in Islamic Shariah and does not include all forms of exploitation. Most definitely, Islam prohibits all forms of exploitation; however, Riba is a technical term and refers to the particular type of exploitation in a loan transaction when something over and above the principal is taken or is charged. Allah in Quran said "Do not do wrong nor be wronged" (2:279). It means that interest either results in injustice to the borrower or sometimes it results in injustice to the lender. That is why, lending or borrowing and taking or giving interest both are not allowed in Islam.

More importantly, prohibition of interest is also due to its discouraging effects on enterprise. If one wants to invest money to earn profit, Islam has allowed trade over lending for interest. If one does not want to invest money for profit, but has some surplus funds, Islam has encouraged spending in charity over lending for interest $(2: 276)$. This second directive is testimony to the fact that prohibition of interest is inclusive of a situation where the lender has surplus funds. These surplus funds are better to be spent on society for gain in life hereafter.

Furthermore, interest like stealing is prohibited in absolute sense. Since a poor cannot be allowed to steal, a needy person can also not be allowed to lend for interest. Mutual funds, REITs, venture capital financing and micro equity 
financing as discussed later can rescue the widows, retirees and other poor masses.

\section{Sources of Income Permissible In Islam}

Every source of income in which benefits are enjoyed by all the concerning parties on the just basis.

\section{Sources of Income Prohibited In Islam}

a) Bribery (Al-Baqarah: 188).

b) Usurping others' property (AI-Baqarah: 188).

c) Fraud (AI-Imran: 161).

d) Stealing and Robbery (Al-Maida: 38).

e) Income from sources of vulgarity (Al-Noor: 19).

f) Gambling (Al-Maida: 90).

g) Wine and its business (Al-Maida: 90 ).

h) Interest (Al-Baqarah: 275).

\section{Moral Directives of Islam in Conducting Business}

\section{Moral Conduct in Entrepreneurship}

"And measure full when you measure. And weigh with an even balance. This is better and its end is good." [Al-Bani-Israel: 35].

"They who hoard up gold and silver and spend it not in the way of God, unto them give tidings (O Muhammad) of a painful doom." [Al-Tauba: 34].

"You resort to oaths as instruments of mutual deceit, so that a person might take greater advantage than another; although, Allah puts you to the test through this. Surely, on the Day of Resurrection, He will make clear the truth concerning the matters over which you differed." [Al-Nahl: 92].

"Who so desires the reward of the world, then with Allah is the reward both of the world and of the Hereafter. And Allah is Hearing, Seeing." [Al-Nisa:134].

"And that the man will not get but what he endeavors. And that his endeavor shall soon be seen." [An-Najm: 39-40]. 


\section{Proposal for Islamic Economic Framework}

"O Believers! Whenever you lend money for a particular period, write and someone among you must write it justly. And the one who can write must not refuse." [Al-Baqara: 282].

Prophet Muhammad (PBUH) has said that "Almighty Allah's mercy descends on one who is gentle at the time of buying, selling, and requesting payment." [Tirmizi].

Prophet Muhammad (PBUH) said: "whosoever sells a defective product without disclosing its defect to the purchaser, shall earn the permanent anger of Almighty Allah and the angels continuously curse such a person." [Ibn-e-Maja].

Prophet Muhammad (PBUH) has exhorted that we should refrain from taking oaths unnecessarily; for although, it helps in the sale of one's products, it reduces the blessings. [Bukhari; also in Muslim].

Abu Qatadah related that the Prophet said: "If anyone would like Allah to save him from the hardships of the Day of Resurrection, he should give more time to his debtor who is short of money, or remit his debt altogether." [Muslim]

Abu Huraira narrated that the Prophet said: "A time will come upon the people when one will not care how one gains one's money, legally or illegally." [Bukhari].

It is reported by Jabir that the Prophet said: "The flesh and body that is raised on unlawful sustenance shall not enter Paradise. Hell is more deserving to the flesh that grows on one's body out of unlawful sustenance." [Ahmad].

Abu Said related that the Prophet said: "The truthful and trustworthy businessman will be in the company of Prophets, saints and martyrs on the Day of Judgment." [Darimi, Tirmidhi].

Abu Huraira reported that the Prophet of Allah (saaws) said, "And what is most likely to send people to Paradise? Being conscious of Allah and good manners." [Bukhari, Tirmidhi \& Ahmed].

\section{Islamic Teachings and Unethical Trade Practices}

"Allah will deprive usury of all blessing, but will give increase for deeds of charity" [Al-Baqara: 276].

Keeping the commodities of general use in possession and not supplying them in the market for the sake of increasing the price is prohibited [Ahmed-Bin-Hanbal: 19802].

Narrated Jabir Ibn Abdullah: Allah's Messenger cursed the accepter of interest and its payer, and one who records it, and the two witnesses; and he said: They are all equal [Muslim]. 
"Woe to those that deal in fraud, those who, when they have to receive by measure from men, exact full measure, but, when they have to give by measure or weight to men, give less than due. Do they not think that they will be called to account?" [Al-Mutaffifin:1-4].

The Apostle of Allah (PBUH) cursed the one who pays bribes and the one who takes bribes. [Abu Dawud, Hadith no 3573].

Bidding more and more only for deceiving is prohibited [Bukhari: 2167].

Trying to buy commodities before they reach market is prohibited because market will decide the price [Muslim: 1517].

\section{Futures \& Forward Trading: Islamic View}

Ibn Abbas (May Allah be pleased with Him) reported Allah's Messenger (PBUH) as saying: "He who buys food grain should not sell it until he has taken possession of it." [Muslim].

\section{Analogical Deduction in Matters: Islamic View}

Nu'man b. Bashir (Allah be pleased with Him) reported: "I heard Allah's Messenger (PBUH) as having said this (and Nu'man pointed towards his ears with his fingers): What is lawful is evident and what is unlawful is evident, and in between them are the things doubtful which many people do not know. So he who guards against doubtful things keeps his religion and honor blameless, and he who indulges in doubtful things indulges in fact in unlawful things, just as a shepherd who pastures his animals round a preserve will soon pasture them in it. Beware, every king has a preserve, and the things God has declared unlawful are His preserves. Beware, in the body there is a piece of flesh; if it is sound, the whole body is sound and if it is corrupt, the whole body is corrupt." [Bukhari; also in Muslim].

\section{Benefits of Honest Conduct in Partnership}

Prophet Muhammad (PBUH) has said that Almighty Allah proclaims: "I am a one third partner of a two man partnership until one of them acts dishonestly to his partner, and, in such an event, I then leave them." [Abu Daud].

\section{The importance of Paying One's Liability}

It is narrated by Abu Musa Ashari that the Prophet said: "After the major sins which must be avoided, the greatest sin is that someone dies in a state of debt and leaves behind no asset to pay it off." [Darimi] 
Job Responsibility of Employee: Islamic View

Narrated Abu Musa Al-Ashari: The Prophet said, "The honest treasurer who gives willingly what he is ordered to give, is one of the two charitable persons, (the second being the owner)." [Mishka'at]

\section{$\underline{\text { Responsibility of Employer: Islamic View }}$}

Prophet Muhammad (PBUH) said: "Give the labor his wage before his sweat dries". [lbn-e-Majah]

\section{Justice and Honesty: Islamic View}

"O believers! Stand firmly for justice, giving witness for Allah, may be therein your own loss, or of your parents or of your relations. Against whom you be a witness, he be a rich or be a poor, in any case Allah has more power than anyone over them, therefore follow not passion lest you may be far away from justice; and if you distort or turn your face, then Allah is aware of your doings." [Al-Nisa: 135]

"O believers! Stand-up firmly by the Commandments of Allah, bearing witness with justice and let not the enmity of any people incite you that you should not do justice. Do justice that is nearer to piety and fear Allah, undoubtedly, Allah is aware of your doings." [Al-Maida: 8]

\section{Gender \& Ethnic Discrimination: Islamic View}

'O people! We created you from one man and one woman and made you divided in branches and tribes so that you may recognize one another. Undoubtedly, the most respected among you in the sight of Allah is he who is more pious, verily, Allah is knowing, Aware. [Al-Hujurat: 13].

\section{Directives of Islam to an Earning Individual}

\section{Encouragement for Welfare Spending}

...Remember, the example of those who spend in the way of God is like that of a grain, which sprouts into seven ears, producing a hundred grains in each ear. God [by His mercy] increases manifold [the rewards of such deeds] for whom He wills. And Indeed, God is extremely bountiful [in rewarding His servants], fully aware [of your circumstances and deeds]. [Al-Baqara: 261].

"Those needy ones who are wholly wrapped up in the cause of Allah, and who are hindered from moving about the earth in search of their livelihood especially deserve help. He who is unaware of their circumstances supposes them to be wealthy because of their dignified bearing, but you will know them by their countenance, although they do not go about begging people with importunity. 


\section{Proposal for Islamic Economic Framework}

And whatever wealth you will spend on helping them, Allah will know of it." [AlBaqara: 273]

"Look, you are being called upon to expend in Allah's Way, yet some of you are being niggardly, whereas the one who is niggardly is, in fact, being niggardly only to himself. Allah is Self-Sufficient: it is you who are the needy. If you turn away, Allah will replace you by another people, and they will not be like you." [Muhammad: 38]

"(O Prophet!) Tell those of My servants who believe that they should establish Prayer and spend out of what We have provided them with, both secretly and openly, before there arrives the Day when there will be no bargaining, nor any mutual befriending." [Ibrahim: 31]

"Have you seen him who belies the rewards and punishments of the Hereafter? $\mathrm{He}$ it is, who drives away the orphan and does not urge giving away the food to the poor." (Al-Ma'un: 1 - 3)

Those who blame Muslims who give charity willingly and laugh at those who get nothing but with their hard labor, Allah will punish them for their laughing and for them, is the painful. [Al-Tauba: 79]

Asmah related that the Prophet said: "Spend, and do not count, lest Allah counts against you. Do not withhold your money, lest Allah withholds from you. Spend what you can." [Bukhari; also in Muslim].

Abu Huraira related that the Prophet said: The Lord's commandment for every one of His slaves is, 'Spend on others, and I will spend on you'. [Bukhari; also in Muslim].

\section{Attitude of the giver of charity}

"Those who spend their wealth in the way of Allah and do not follow up their spending by stressing their benevolence and causing hurt, will find their reward secure with their Lord. They have no cause for fear and grief.

To speak a kind word and to forgive people's faults is better than charity followed by hurt. Allah is All-Sufficient, All-Forbearing.

Believers! Do not nullify your acts of charity by stressing your benevolence and causing hurt as does he who spends his wealth only to be seen by men and does not believe in Allah and the Last Day. The example of his spending is that of a rock with a thin coating of earth upon it: when a heavy rain smites it, the earth is washed away, leaving the rock bare; such people derive no gain from their acts of charity. Allah does not set the deniers of the Truth on the right way." [AlBaqara: 262 - 264] 


\section{Proposal for Islamic Economic Framework}

\section{Islamic View on Unscrupulous Consumption}

"Give to the near of kin his due, and also to the needy and the wayfarers. Do not squander your wealth wastefully; for those who squander wastefully are Satan's brothers, and Satan is ever ungrateful to his Lord." [Al-Bani-Israel: 26 - 27]

"Do not keep your hand fastened to your neck nor outspread it, altogether widespread, for you will be left sitting rebuked, destitute." [Al-Bani-Israel: 29]

"Those people, who when they spend, are neither extravagant nor miserly but keep the golden mean between the two (extremes)" [Al-Furqan: 67]

Amr lbn Shuaib, on his father's authority said that his grandfather related that the Prophet said: "When you eat, drink, give charity and wear clothes, let no extravagance or pride be mixed up with what you do." [Ibn Maja; also in Nasai].

\section{Stinginess \& Wealth Accumulation: Islamic View}

"Those who do not spend their wealth that has been given to them by Allah must not think that it is good for them; indeed it is bad for them (Al-Imran: 180)".

..."Allah does not love the arrogant and the boastful, who are niggardly and bid others to be niggardly and conceal the bounty which Allah has bestowed upon them. We have kept in readiness a humiliating chastisement for such deniers (of Allah's bounty)" Al-[Al-Nisa: 36-37].

Jabir reported that the Prophet said: "Avoid doing injustice to others, for on the Day of Judgment, it will turn into manifold darkness, and safeguard yourself against miserliness, for it ruined those who were before you. It incited them to murder and treating the unlawful as lawful." [Muslim].

Abu Said Khudri related that the Prophet said: "There are two habits which are never present together in a believer: miserliness and bad manners." [Tirmidhi].

Abu Huraira related that the Prophet said: "When someone is made rich but he does not pay Zakat for his wealth, then on the Day of Judgment his money will be turned into a poisonous snake with two black spots on its head. It will coil around his neck and bite his cheeks and say: 'I am your wealth, I am your treasure'. Then the Prophet recited verse 3:180 of the Quran." [Bukhari]

\section{Paying Zakah}

"Say your prayers (Namaaz) and pay Zakah". [Al-Muzammil: 20].

"Establish Prayer and dispense the Purifying Alms (Zakat) and bow in worship with those who bow". [Al-Baqara: 43]. 


\section{Entrepreneurship Vs Dependency}

Narrated Hakim bin Hizam that the Prophet Muhammad (peace and blessings be upon him) said: "The upper hand is better than the lower hand (i.e. he who gives in charity is better than him who takes it). One should start giving first to his dependents. And the best object of charity is that which is given by a wealthy person (from the money which is left after his expenses)." [Bukhari].

\section{Social Responsibility: Islamic View}

Anas related that the Prophet said: "If any Muslim plants something or sows seed from which a man, a bird or an animal eats, it counts as a charity for him." [Bukhari; also in Muslim].

\section{Communal Development: Islamic View}

Abu Huraira narrated that the Prophet said: "The best charity is that which is practiced by a wealthy person. And start giving first to your dependents." [Bukhari].

Salman Ibn Amer reported that the Prophet said: "To give something to a poor man brings one reward, while giving the same to a needy relation brings two: one for charity and the other for respecting the family ties." [Ahmad, Ibn Majah, Nasai, Tirmidhi].

\section{$\underline{\text { Utility and Satisfaction: Islamic View }}$}

Abu Huraira narrated that the Prophet said: "Wealth is not in having vast riches, it is in contentment." [Bukhari; also in Muslim].

\section{Analysis of Economic Practices in the light of Islamic Ethical Principles}

Pal (2006) criticized the traditional approach of comparing Islamic ideals with practiced capitalism. He stated that systems cannot be analyzed judicially with taking ideals of one and the practice of the other.

In this section, we analyze conformity of economic practices with Islamic principles and identify specific ethical issues and deviations in specific sectors of economy at the sector and industry level.

\section{$\underline{\text { Health Industry }}$}

Kickbacks are a common phenomenon in pharmaceutical industry. Less reputable or newly established companies offer kickbacks to doctors to prescribe their drugs. Kickbacks are given in the form of commission, hotel or airline ticket reservation etc. Such companies also compromise on quality and tamper with content and quantity. 
Some doctors take more than one job without taking approval from their principal fulltime employer. Some doctors in public hospitals provide low cost medicines to the suppliers on commission. Some doctors use medicines in public hospitals in their private clinics by using their authority and some of them remain absent from their duties in public hospitals and further their self interest in private clinics. Trading of human organs is also in vogue in this sector.

\section{Information Technology Industry:}

Most of the software companies operating at a lower scale do not use licensed software in their organizations. Often, programmers working in their organization take the proprietary program code and build their own competing software or offer to sale the stolen code to third parties. Sometimes, such software companies to gain market offer solutions at economic rates, but let the program have some bugs due to which the company rehires the firm again and the firm has sufficiently more bargaining power in the maintenance contract. The customers of these software companies often violate copyrights and make pirated copies of software to avoid cost of purchasing expensive licensed software over and again.

\section{Consumer Goods Industries:}

Often, consumer goods producers indulge in deceptive advertising. Tampering with quality and quantity is common. Ingredients written on packaging do not often match in reality. Due to strict quality standards worldwide, they often do not make into the international market. But, since supervision of quality standards lag in most Muslim countries as most of them are developing countries and lack resources to protect environmental damage, they get away with low quality standards in the domestic market. Though, utility maximization does not contradict with Islamic principles, but, when it is maximized using liquor, intoxicants, indulging in consuming/selling vulgar silver screen content etc, it is not recommendable as per Islamic ethical principles.

Targeted sales are achieved giving sales team concrete sales targets. To achieve the sales targets, the members of the sales team often use deceptive information, over commit on quality and performance to produce the sales. Since ethical conduct is often not the bottom line in these companies, the companies give better performance appraisal for the members of the sales team who add to the bottom line i.e. profits. That is why, ethical conduct is not only deprived of incentives, but rather it is disincentivised.

\section{Capital Goods Industries:}

Capital goods industries are often neutral to their responsibility to the environment. Wastage of resources polluting environment is very common. License to operate is obtained by offering kickbacks and those who are authorized to provide licenses to rightmost candidates forgo due diligence if offered kickbacks, else they indulged in red tapism. 


\section{Proposal for Islamic Economic Framework}

\section{Agriculture Sector:}

In the agriculture sector, landlords use undue influence to repress tenets. Child labor and even bonded labor is common if a person or his ancestors fail to pay usurious loans. Sharecropping is not always done as per the terms of the contract. Property rights are not enforced everywhere and might is right prevails where there is lack of property rights and law enforcement.

In trade of perishable commodities, middlemen use undue influence to obtain goods at cheap prices as warehouses and marketing channels are outdated and insufficient. In trade of commodities, supply is deliberately restricted to raise prices i.e. hoarding.

\section{Financial Sector:}

In financial sector, agency problem between shareholder and management and between management and creditors raises ethical issues. Management often works to serve its interests at the cost of either creditors or shareholders. Moral hazard is common in financial institutions whereby the management may be less diligent and responsible in providing loans to candidates since the money involved is not their own, but of shareholders or creditors. Having asymmetric information, investors can take benefit of some private information which is not made public. This asymmetric information is also marketable for kickbacks. In financial institutions, gambling and interest is rampant and is a deviation from Islamic prohibition of interest and gambling.

In mergers and acquisitions and privatization of public companies, due diligence is not always carried out appropriately. In most developing countries, some of the most strategic national assets in the form of public companies were sold at below market or book value prices. Transparency, due diligence, corruption and conflict of interest are the major ethical issues in such situations.

\section{General Ethical Issues in Work Ethics:}

Justice and honesty are the virtues of utmost importance in all religions and other comprehensive doctrines. As per Islam, the job one gets to do is a trust. One needs to honor the trust. This implies that one ought to perform due diligence in all respects of one's job. Its more practical implication is that one ought to utilize the resources, abilities and authority in the best possible manner. Theft, crime (blue color or white color), situations creating conflict of interest, non-compliance to due diligence etc are all pretty common deviations from Islamic ethical principles present and observed in our society.

In recruitment, favoritism and nepotism are the major ethical issues to deal with. Though, corporations brag about being an equal opportunity employer, but often, some discrimination on the basis of ethnicity and gender is practiced in an undocumented way. 


\section{Chapter 4}

\section{ECONOMIC SYSTEMS}


In this information age, it is a tragedy that humans are regarded as subservient to systems. Some of the modern thinkers make humans seem mere tools and not able to influence systems. Systems did not get functional by themselves. It is not like that systems were running on their own and humans became part of the systems. In post modernism literature, Marcuse (1964) has described this phenomenon of regarding humans subservient to systems as 'One Dimensional Man' in his book with the same title.

Humans indeed make up the socio-economic systems and who can change them for better. Systems do not need to be modified or altered if they are stable and providing the benefits for which they are created and made to operate. But, if they are not providing the desired results, they can and should be altered to provide the desired results. Not realizing this, we've given way to interest based financial system which has brought inequality and consumerism whereby a Company selling edibles can invest millions of dollars on advertisements while two-thirds of the world's human population consists of poor who can't even afford them regularly.

Indeed, when one sees poor, ill-fed, malnourished children on one side and observe multinationals investing millions of dollars in ad campaigns to market durables and luxuries which most cannot afford, it provides a strong enough reason to revisit the systems.

Economists thought depression is a thing of the past up until now when the unprecedented financial crisis of 2007-09 has reached a scale which hardly anybody could forecast. There is already debate on replacement of Breton woods and search for alternates.

This is a critical time when economists can offer untried remedies after thorough research for getting out of the financial crisis and provide holistic, stable, robust, equitable yet a practicable system.

In this backdrop, this chapter takes an analytical approach to revisit the fundamental postulates of major economic systems and identify the structural issues which need to be addressed in the pursuit of economical revival in the short term and furtherance of millennium development goals in the long run.

\section{Central Problems of an Economy}

The central problems of an economy revolve around one of the most important aspects of human life that our resources are scarce to fulfill our unlimited wants. The scarcity of resources creates a dilemma for economic managers who have to make a choice from among the set of alternatives. To make the economic choices, economists and economic managers confront following questions: 


\section{What to Produce?}

Resources are scarce as compared to unlimited wants. Not all of the goods and services can be produced with the given set of human, physical, technical resources and capital. Countries have to choose between a long list of goods and services, the particular goods and services that they want to produce given the demand, social and economic needs and limited resources they possess.

Adam Smith provided the initial answers by arguing that absolute advantage dictates the choice that which goods a country should produce. David Ricardo provided an alternative explanation which is still regarded as a more plausible explanation for allocation of scarce resources on production of goods and bilateral trade. He stressed that comparative advantage determines allocation of resources i.e. countries produce and trade in goods in which they have comparative advantage.

Heckscher-Ohlin model stated that countries produce the goods which are made with the factor endowments that a country has in abundant supply. Paul Krugman working on economic geography and finding reasons why some countries import and export the same goods enriched our knowledge by explaining that economies of scale and product differentiation are the reasons for such happenings.

\section{How Much To Produce?}

Even if a country produces a particular set of goods, it cannot produce them in unlimited quantities. If all the resources are devoted for producing only one good or service, no resources will be left to produce other goods and services.

\section{How to Produce?}

Globalization has stimulated the competition and the need to seek cheap methods and location where cheap labor and resources could be procured and markets can be effectively reached to minimize costs. Countries have to decide how best they can achieve the level of production with the limited amount of resources they have.

\section{When to Produce?}

Predicting demand changes is important for survival. All the countries and corporations want to sell but they also do not want to end up with excess supply and lesser returns. With increase in population, countries have to increase their production of all goods and services to avoid inflation. 


\section{For Whom to Produce?}

Not all the people can be accommodated in their desires due to scarcity of resources. The choice of production in goods and services, level of production and method of production is made with the specific needs of the market.

\section{Economic Systems}

An economic system is a set of principles on which an economy can run and make decisions about the central problems it faces in the form of scarcity of resources and unlimited wants.

There are following economic systems that the countries adopt in running their economies.
1. Capitalism
2. Socialism
3. Mixed Economy
4. Islamic Economic System

\section{Capitalism}

Capitalism, unlike Islamic economic system and Socialism regards capital as an individual factor of production creditable of distinct factor payment i.e. interest. It supports the capitalists to benefit from wealth accumulation without having to put factor i.e. capital at similar risks that an entrepreneur faces. It shifts the break even line further away from the entrepreneur and crowds out entrepreneurs who cannot afford to keep feeding capitalists. In this regard, interest has a huge influence on allocation of resources. It influences the basic economic decisions like what and for whom to produce.

Capital is needed for technological advancements. It is needed for production and consumption and for governments to expend on development. It is even needed to influence policies by winning elections after expensive election campaigns. There would not have been many complexities if markets were efficient and income and wealth distribution fair. But, the world we live in has never and perhaps never will have perfect equality and perfect competition.

Interest serves capitalists and allows them to accumulate wealth. This is evident from the empirical statistics on inequality in income and wealth in second half of the 20th century when monetary capitalism with institutional support expanded in an increasingly integrated and global economy.

In 2001, there were 1,100 million people living in poverty. But in Sub-Saharan Africa, the number of people in extreme poverty rose to 313 million. (Source: World Development Indicators 2005) 
Hence, much of the technological advancements, increase in production and better standards of living with increase in earning opportunities and welfare expenditure has occurred in that part of the world which was able to accumulate capital effectively than the rest of the world in pre-capitalistic and early capitalistic eras.

\section{Economic Management in Capitalism}

\section{What to Produce?}

Countries produce the goods domestically in which they have comparative advantage and trade the other goods from other countries in which they do not have a comparative advantage. Most countries however strive to have food security and engage in agricultural production even if they do not have comparative advantage in producing farm goods. For instance, most OECD countries do not have comparative advantage in agriculture, but they provide huge subsidies to their farmers to enable domestic production for food security.

\section{How Much To Produce?}

Therefore, countries have to trade-off one good for another between the set of goods that they can produce. The opportunity cost of each good for each country determines the level and variety of output for that country.

\section{How to Produce?}

Cost minimization gives a country comparative advantage in gaining access to other markets and countries. Decrease in price increases demand and revenue (up to a limit). Cost minimization enables a country to increase its production of all goods and services with the same existing amount of resources.

\section{When to Produce?}

Countries have to make decision about future production well in advance to meet the demands of increase in population, changes in tastes and preferences and changes in income. Countries have to produce domestically the goods in which they have comparative advantage and import the other goods to meet demand and to avoid high inflation.

\section{For Whom to Produce?}

Resources are allocated to produce goods that can be bought in the market by people having adequate purchasing power. Purchasing power and current and future income prospects determine the size of the target market and triggers the producers to meet expected demand. Decisions about production are driven by self-benefit and profit maximization objective. 


\section{Fundamental Features of a Capitalistic Economy}

Capitalism is a natural economic system unlike socialism. That is why; it has fared well throughout history, practiced most widely and has outmoded Socialism. Most Socialist countries have adopted features of Capitalism and the growth of China since 1980s after it made a compromise between Capitalism and Socialism (though still not in a holistic way) and adopted some of the important Capitalistic values further strengthen the case to use Capitalism (though modified to suit the needs of a particular country) over outright Socialism.

\section{$\underline{\text { Right of Private Property }}$}

In a capitalistic economy, people have the right to own assets and conduct business. Within legal limits, they have the complete freedom to enter into any business activity be it socially or morally correct or not.

\section{No Government Intervention}

Government does not intervene or its intervention is very minimal. Businesses are allowed to produce anything and charge any price they wish as long as they can find buyers who can afford their goods and services. Therefore, a capitalist seeks maximum return for his capital and keeps all things secondary to it.

\section{Freehand to Market Forces}

Market forces of demand and supply are allowed to work freely. Government does not intervene in setting the prices or level of output in a model capitalistic economy.

\section{$\underline{\text { Reliance on Invisible hand }}$}

It is assumed that every person acting in his/her own benefit will keep the economy running in an efficient way. Everyone is allowed to work in his/her benefit and is not obliged to think about society and its needs. It is assumed that social objectives will be met with people working for their own benefits.

\section{Freedom of Choice in Production}

People have outright freedom in production. A capitalist having a higher incentive to produce luxury bungalows and lower incentive to produce low cost apartments will produce luxury bungalows. All decisions are governed by incentives and self benefit and no consideration is given to the needs of the society. Invisible hand is supposed to bring socio-economic order. 


\section{Proposal for Islamic Economic Framework}

\section{Freedom of Choice in Consumption}

People have outright freedom to consume whichever goods they like as long as they can afford them. Consumers seek maximum utility and do not have obligation to share their wealth with the poor masses apart from compulsory taxes. Materialism, self benefit and apathy are the hallmarks of the capitalistic society.

However, in most capitalistic countries, government does play a role and impose taxes to deal with externalities, identify and correct anti-competitive practices, provide subsidies to support a commercial project which may not be attractive for private investors from the viewpoint of NPV and thereby subsidies provide incentive to undertake these projects. In most capitalistic countries, defense, utilities, communication, transport etc are run in public sector.

\section{Critical Analysis of Capitalism}

Interest is prohibited in all monotheist religions (See Exodus 22:25, Leviticus 25:35-36, Deuteronomy 23:20, Psalms 15:5, Proverbs 28:8, Nehemiah 5:7 and Ezekiel 18:8,13,17 \& 22:12). However, interest is pervasive in capitalism.

Even among secular literature, one finds criticism on interest. Aristotle (384-322 $\mathrm{BC}$ ) in his book "Politics" criticized interest in following words "Of all modes of getting wealth, this is the most unnatural". In value neutral economics too, we find criticism on interest. Keynes (1936, p. 377) in his monumental work "General Theory of Income, Employment, Interest and Money" reasoned in following words:

"Interest to-day rewards no genuine sacrifice, any more than does the rent of land. The owner of capital can obtain interest because capital is scarce, just as the owner of land can obtain rent because land is scarce. But whilst there may be intrinsic reasons for the scarcity of land, there are no intrinsic reasons for the scarcity of capital. An intrinsic reason for such scarcity, in the sense of a genuine sacrifice which could only be called forth by the offer of a reward in the shape of interest, would not exist, in the long run, except in the event of the individual propensity to consume proving to be of such a character that net saving in conditions of full employment comes to an end before capital has become sufficiently abundant. But even so, it will still be possible for communal saving through the agency of the State to be maintained at a level which will allow the growth of capital up to the point where it ceases to be scarce".

In one of his famous essay, Keynes (1932, p.358) reasoned as follows:

When the accumulation of wealth is no longer of high social importance, there will be great changes in the code of morals. We shall be able to rid ourselves of many of the pseudo-moral principles which have hag-ridden us for two hundred years, by which we have exalted some of the most distasteful of human qualities into the position of the highest virtues. We shall be able to afford to dare to 
assess the money-motive at its true value. The love of money as a possession as distinguished from the love of money as a means to the enjoyments and realities of life - will be recognized for what it is, a somewhat disgusting morbidity, one of those semi-criminal, semi-pathological propensities which one hands over with a shudder to the specialists in mental disease ...

But beware! The time for all this is not yet. For at least another hundred years we must pretend to ourselves and to everyone that fair is foul and foul is fair; for foul is useful and fair is not. Avarice and usury and precaution must be our gods for a little longer still. For only they can lead us out of the tunnel of economic necessity into daylight"

Milton Friedman, one of the most distinguished monetary economists argued that nominal interest rate be kept at zero. He reasoned that the marginal cost of creating additional money is zero. Therefore, nominal rates of interest should be zero. It implies that the central bank should keep rate of deflation equal to the real interest rate on treasury bonds so that the nominal interest rate are kept at zero. This also obviates the need for indexation and it also helps in increasing output and employment.

Among most recent economists, Krugman [September 02, 2009] in his New York Times article titled "How Did Economists Get It So Wrong?" analyzed the current financial crisis in following words:

"Until the Great Depression, most economists clung to a vision of capitalism as a perfect or nearly perfect system. That vision wasn't sustainable in the face of mass unemployment, but as memories of the Depression faded, economists fell back in love with the old, idealized vision of an economy in which rational individuals interact in perfect markets, this time gussied up with fancy equations... Unfortunately, this romanticized and sanitized vision of the economy led most economists to ignore all the things that can go wrong. They turned a blind eye to the limitations of human rationality that often lead to bubbles and busts; to the problems of institutions that run amok; to the imperfections of markets - especially financial markets - that can cause the economy's operating system to undergo sudden, unpredictable crashes; and to the dangers created when regulators don't believe in regulation.

... So here's what I think economists have to do. First, they have to face up to the inconvenient reality that financial markets fall far short of perfection, that they are subject to extraordinary delusions and the madness of crowds."

Sameulson (1948) in his criticism on extra reliance on market forces stated that market forces will only lead to 'starving couples' to malnourished children who grow up to produce malnourished children, to perpetuation of Lorenz curves of great inequality of income and wealth for generations or forever.

Among Muslim Economists, Siddiqui (2002) criticized interest stating that even in commercial loans, the borrower may suffer a loss, yet interest based lending 
obliges him/her to repay the principal plus compound interest. Conversely, the borrower may reap huge profits, yet the lender gets only the stipulated rate of interest which may likely turn out to be small part of the actual profits. It results in inefficient allocation of society's resources and increases the inequality in the distribution of income and wealth as it guarantees a continuous increase in the monies lent out, mostly by the wealthy, and puts the burden of bearing the losses on entrepreneurs and through loss of jobs on the workers.

Chapra (1993) viewed secular societies continuing to belittle the need for moral development; though all of them now profess commitment to development with justice. He emphasized that even material development with justice is not possible without moral development. The rationale for this contention is that development with justice requires an 'efficient' and equitable use of all resources and both 'efficiency' and 'equity' can neither be defined nor actualized without the injection of a moral dimension into economic pursuits.

He outlined unrealistic assumptions in capitalism which will not make invisible hand alone to address the issues of equity:

1. Harmony between individual and social interest e.g. unscrupulous consumption and imposing externalities on society.

2. Individual preferences reflect social priorities e.g. precedence of self interest over social priorities.

3. Equal distribution i.e. unequal distribution of income gives more weight to resourceful class to influence allocation of resources to their desired use.

4. Prices reflect urgency of wants i.e. no mechanism to differentiate between necessities and not so necessities, e.g. want satisfaction of few does not mean need satisfaction of all especially when resources are scarce and can only be used for alternative uses.

5. Perfect Market i.e. price mechanism can have a minimum impact on socially desirable allocation of resources; it works when there is perfect competition. But, market imperfections even dilute this little influence that price mechanism could have on socially desirable resource allocation when prices are completely out of line of real out-of-pocket costs.

6. Social Darwinism i.e. richest are the fittest to survive by the sheer weight of their purchasing power to influence the resource allocation.

Theory of Comparative Advantage states that resources should be allocated to the efficient sectors of the economy. If U.S.A has a comparative advantage in producing cars and if Pakistan has a comparative advantage in producing wheat; then, Pakistan should allocate its resources on producing wheat and U.S.A should allocate its resources to produce cars. Both Pakistan and U.S.A can gain from exchange and specialization. 
But this will only work when the trade is fair and when both countries do actually allocate their resources to their efficient sectors. Instead what happens is that developed countries have absolute advantage in producing most goods over developing countries. Developed countries allocate their resources in producing goods that they can produce most efficiently and use the proceeds from sale to provide subsidies to their inefficient sectors and virtually paralyze the developing economies by depriving them of their chance of gaining through exchange and specialization.

The export subsidies provided by developed countries to their inefficient sectors enable the inefficient sector to become efficient artificially and crowd out the developing countries by overproducing and then dumping these goods in the third world countries. If the supply exceeds demand, developed countries have not been reluctant to dump their production in sea if they can't do it in the developing countries!

By providing export subsidies to their inefficient sectors, developed countries create distortions in trade and misappropriations in resource allocation. The export subsidies paid by the developed countries to their inefficient agriculture sector are funded through the proceeds of exports. Therefore, effectively these subsidies are paid by the developing countries. Developed countries charge huge premium for value addition that is not in line with their out-of-pocket costs. The difference is especially huge in information technology products, software and pharmaceuticals. Once software or medicine is made, the capacity is virtually unlimited. Unlimited copies can be sold provided there is enough demand. Cost per unit is spread over larger output. At higher levels of output, marginal cost is negligible in these products.

Therefore, developing countries are denied gains from comparative advantage in agriculture through export subsidies provided by developed countries to their comparatively inefficient agriculture sector. Subsidies of $\$ 350$ billion a year to agricultural producers in OECD countries are a barrier to developing country exports (Source: World Development Indicators 2005). This creates unemployment and poverty in the developing economy. Eventually, a developing country will have to submit itself before the international financial institutions that are able to exert extraordinary influence -not limited to economic but also political- in the developing country. Therefore, the role of IMF, World Bank, WTO and the adaptation of Structural Adjustment Program and Free-Float exchange rate systems are all interrelated in their objectives to maintain the status quo of supremacy of developed world over developing countries.

Zaidi (2005, p.328) on analyzing the effects of IMF policies and Structural Adjustment Program pursued in Pakistan, reasoned in following words:

"Such programmes have very serious negative impacts on growth, inflation, income distribution, the social sectors, and poverty. In general, Structural Adjustment Programmes have made matters far worse for countries that have followed them. We have examined the philosophy that governs such adjustment programmes, which is essentially one of liberalization, openness, and greater 


\section{Proposal for Islamic Economic Framework}

integration with the new economic world order, and we have found that not just the adjustment programmes themselves, but also the thinking behind them does not take account of specific factors and the context of specific countries."

In WTO system, developing countries are given some extra time to restructure themselves than the developed countries. But, the time limit is very short for an economy to restructure itself. Small economies with little population are able to restructure themselves like some of the East Asian countries. But, the tropical countries with agrarian economies and huge population are not able to restructure themselves so quickly.

Industrial revolution came in mid $18^{\text {th }}$ century. Capitalism as we know had its roots in as early as in the 15th century. Even then, the change from agrarian based economy to industrialized economy was not rapid. Similarly, information revolution in the last two decades needed a maturing industrial revolution as a preset. Therefore, if it took centuries for Europe to restructure their economies, how can developing countries are expected to restructure themselves in less than a decade!

The shallowness of the WTO is evident from the fact that it has not addressed following key areas in international trade and politics.

- Oil trade is completely out of WTO influence

- $\quad$ No agreement on smuggling

- No agreement on anti-money laundering

- Drug trafficking is out of WTO influence

\section{$\underline{\text { Need for Redefining Priorities }}$}

After providing exemplary standard of living to their citizens, developed countries embarked upon providing such luxury to animals as well. But, humans should have more value than animals! This assertion will not look odd when they will have to trade off between their citizens and engendered species! Using TBT (Technical Barriers to Trade), SPS (Sanitary and Phyto Sanitary) measures, environmental excuses and safety measures for saving extinct species while the developed world is responsible for most of the world's pollution and climatic change is completely baseless. High-income countries account for half the world's $\mathrm{CO}_{2}$ emissions (Source: Carbon Dioxide Information Analysis Center data).

Less is better if it is distributed fairly equally than more wealth distributed unequally. Efficiency measures need to include social objectives. Priorities need to be set right and there should be a worldwide consensus on the following issues: 


\section{Growth Vs Development}

Growth is important but development is pivotal. Growth that does not result in development is less desirable. Reducing inequality is more important than increasing the growth rate.

\section{Profit Optimization Vs Social Optimization}

Social Optimization is more important than Profit Optimization. Achievement of social optimization if not possible solely through the private sector, it must be brought about through government intervention.

\section{What goes around comes around!}

Reducing trade barriers is said to benefit consumers as they will have range of competitive products at their disposal. But, consumers earn through factor payments that come through producers. If domestic producers will be crowded out of the market in a no-trade barrier regime; then, consumers will lose jobs and their purchasing power will decrease subsequently. Furthermore, it may also cause brain drain. Therefore, in the long run, it merely becomes a zero sum game.

Summarily, as a capitalist, one even with the knowledge that weapons one sells will kill millions in Africa, would not bother as that is what he does for profits as a capitalist. Though, one may favor democracy in principle, but if nationalistic interests are better served by dictators, one will bear them as a head of state of a country in a developed world. Though, one may favor progressive taxation in principle, but if indirect taxes can pay back loans smoothly, one may direct imposition of indirect taxes in developing countries as a chairman of IMF or World Bank.

\section{Socialism}

Some of the pioneer and well known social thinkers include Robert Owen, Charles Fourier, Pierre-Joseph Proudhon, Louis Blanc, Charles Hall and SaintSimon. Socialism was to act as a pre-cursor to Communism. Karl Marx described socialism as a specific historical phase that will displace capitalism as a precursor to communism. Socialism does not promise to make everyone equal and pay everyone the same wages and replace market economy in a complete sense. However, communism does promise income and social equality. Some of the well known social leaders include Vladimir Lenin and Joseph Stalin. Some of the important countries that tried Socialism include Russia, Hungary, Poland, Romania, Vietnam, Yugoslavia etc. Just before Great Depression, the socialist movement was at its peak. Most socialist countries fared very well in Great Depression and only Capitalist countries suffered in Great Depression. This also caused appreciation for Socialism at the point in history. 


\section{Fundamental Features of Socialism}

The salient features of Socialism are discussed below:

\section{Collective property}

In a socialist economy, there is no right to own private property. All the property collectively is in the ownership of the socialist government in the country. This means that all the business enterprises are in the collective ownership, management and control of the government.

\section{Planned Economy}

The government in its own wisdom solves the central problems of the economy. Decisions like what to produce? how to produce? When to produce? for whom to produce? and how much to produce? are all taken by the government. All the economic planning and policy making rests with the government.

\section{Decisions in Collective Interest}

All the decisions are made by the government in the collective interest of a socialist country. People are directed to follow the instructions of the government and are not allowed to object to any decision or policy of the socialist government.

\section{Reduced Income Inequality}

Government makes the decisions about the wages arbitrarily. The wages are forced to remain in parity in all fields. Government tries to keep income equality through setting the wages and disallowing any objection or bargaining.

\section{$\underline{\text { Restriction on Market forces }}$}

Market forces of demand and supply are not consulted by the government in a socialist economy. Market mechanism does not prevail and all the decisions are made by the government in its own wisdom.

\section{Centralized Economy}

All the decision-making authority rests with the government. No one else is given the authority to make the economic decisions even for oneself. Everyone has to follow the commands of the government and everyone is treated like an employee of the government. 
Non-existence of Private sector

Private sector is non-existent in a socialist economy. No private economic activity is allowed. Every person has to work for the government and earn wages that are set arbitrarily and are not determined on the basis of quality or nature of the work.

\section{Critical Analysis of Socialism}

On the economic criticism of Socialism among Muslim economists, Maududi (1970) analyzed that socialism in its quest to tame capitalists brought one big capitalist in the form of government i.e. communist party accredited with the responsibility to operate, manage and administer the overall economy without giving society and individuals any recourse to challenge the government. In such a case, no government, consisting of humans after all can keep itself judiciously pursuing common goals than individual goals. Usmani (2003) reasoned that socialism kills the self motive which drives individuals to excel and be efficient.

The predictions of Marx about Capitalism also did not materialize and his Theory of Surplus Value was also criticized later on. The problem in distribution of income in Capitalism from an Islamic perspective was only with interest. Land has an intrinsic value and its owners receive rent on land. Labor also earns wages even when the entrepreneur suffers loss. Value of production i.e. prices of goods is not always sufficient to create surplus after paying wages, rent and interest. While laborer earns wages for work it renders and the land owner earns rent for the use of land, money cannot have a separate compensation of its own until it transforms itself as capital and take the risk of entrepreneurship along with an entrepreneur.

Toutounchian (2006) also differentiated between money and capital and reasoned that if capital is combined with labor, it produces profit, but if money alone is lent, the interest it earns is not permissible.
$M:\{(1) L=100 \%$;
(2) $\mathrm{V}>1$;
(3) $\mathrm{MC}=0$;
(4) $d=0$;
(5) ó=0;
(6) $R=r\}$
$K:\{(1) L<100 \%$;
(2) $\mathrm{V}=1$;
(3) $\mathrm{MC}>0$;
(4) $d>0$;
(5) ó>0;
(6) $R=\tilde{n}\}$

Where: $\mathrm{L}=$ liquidity; $\mathrm{V}=$ velocity $; \mathrm{MC}=$ marginal cost; $\mathrm{d}=$ depreciation

$R=$ return; ó = risk; $r=$ rate of interest; and $\tilde{n}=$ rate of profit

On the political criticism of communism, Fukuyama (1992) argued that following the collapse of the Soviet Union, liberal democracy no longer faced any serious ideological challenges and thus had proved itself to be the only sustainable and successful form of government. Marx used the phrase 'the end of pre-history' to symbolize the victory of communism over capitalism. Fukuyama claimed that 
capitalist liberal democracy would ultimately extend to all nations and this would be 'the end of history'.

\section{Mixed Economy}

Mixed economy is a compromise between capitalism and socialism. A mixed economy takes the valuable features of both. Some mixed economies can be tilted more towards socialism and some can be tilted more towards capitalism. However, most countries can be classified as mixed economies in the real world.

\section{Fundamental Postulates of Mixed Economy}

In the following lines, few fundamental features of a mixed economy are briefly stated.

\section{Coexistence of Public and Private Sector}

In a mixed economy, public and private sector work in parallel to each other. Usually, the public sector is responsible to provide transport, communication, defense, currency management, utilities like telephone, water, gas, electricity etc. All the other industries are in the ownership of private sector.

\section{Government Regulation and Prices}

Unlike in Capitalism, Government intervenes in the market to regulate prices. Governments give subsidies to encourage production of necessities and their cheap availability to the poor masses. On the other hand, high tariff rates are imposed on luxuries with inelastic demand.

\section{Government Regulation and Market Imperfection}

Government intervenes in industries where cartels are formed. It disallows cartels and regulates oligopoly, and monopoly. The government sometimes set a ceiling price for goods and services to put check on monopolies and reduce the burden of inflation on poor people.

\section{Government Intervention and Income distribution}

Government intervenes to redistribute income through progressive taxes, setting ceiling prices for necessities and setting minimum wages. The government also provides tax holidays, tax credits, tax rebates and other concessions and incentives to promote a particular social activity, economic activity or socioeconomic class. 


\section{$\underline{\text { Public Sector and Social Objectives }}$}

Usually, the public sector is responsible to provide transport, communication, defense, currency management, utilities like telephone, water, gas, electricity etc. Government provides subsidies to public enterprises so that these enterprises do not increase their prices to cover their losses. Government sometimes bears losses to avoid public displeasure in the form of inflation.

\section{Promotion of Private Sector}

Even though the government intervenes in the hour of need, it still provides incentive to the private sector and a level playing field to compete with the public sector. In industries where public sector and private sector coexist, government lets the market forces work and does not crowd out the private sector.

\section{Deregulation, Liberalization and Privatization}

Governments in mixed economies encourage private sector to take on public sector enterprises that are not running efficiently or can be better run by the private sector. It enables the government to act as a regulator rather than a business entity.

\section{Critical Analysis of Mixed Economy}

Though Mixed economy has solved some of the problems in laissez-faire and Anarcho-Capitalism, but it still lacks an ethical foundation to foster social optimization and development at a grand scale i.e. to influence social and human development. Secondly, it has retained interest free financial system which has created at least two havocs i.e. one in East Asia in 1990s and the Great Recession since 2007 in the short two decade long post-soviet union era. Therefore, much of the criticism that is made on Capitalism holds true for Mixed economy as well.

\section{Islamic Economic System}

Islamic economic system in its true sense is not present in any country. However, its salient features and important values can be discussed. It is a blend of natural features present in Capitalism i.e. right to private property, private pursuit of economic interest, use of market forces etc used along with some distinct features derived through Islamic economic teachings i.e. interest free economy, moral check on unbridled self-pursuit and provision of socio-economic justice to achieve the goals of Socialism as far as is naturally possible without denying individual freedom and incentives. 


\section{Fundamental Features of Islamic Economic Order}

Some of the distinct features of an Islamic economic system are discussed below:

\section{Equitable distribution of Income}

Islam through the system of Zakah reduces the Gap between the rich and poor. It is a progressive system of taxation. It levies a special tax on cash, cash equivalents and capital in excess of need that makes sure that the money circulates and is used in the productive activities. Since it is not only a state obligation but a religious obligation, it will not result in tax evasion. It reduces confinement of wealth in few hands.

\section{Prohibition of Interest}

Islam prohibits interest to relieve the society from the exploitation of capitalist. It encourages entrepreneurship and trade. It relieves the society from the disincentive to produce in an interest-based system. It encourages circulation of wealth.

\section{Spending in the way of Allah}

Islam directs Muslims to pay Zakah. Besides, it encourages people towards charity to help poor and gain benefit in the hereafter. Only with the knowledge of life after death and the belief in God, can one decide to act morally as an end in itself and not merely as means to a material end. Moral act in Islam also is a means to an end i.e. to achieve eternal success and blessings of God. But, it is not a material end confined to this life only. In this way, the utilitarian mind is also satisfied as happiness is a relative term not achieved only by material things. The fact that moral actions even if they are not rewarded in this world will be rewarded in life hereafter satisfies the utilitarian mind.

\section{Protection of Rights}

Islam unlike socialism does not put restriction on private property. It allows people to own assets, conduct trade and business as long as they avoid any immoral act.

\section{Provision of Justice}

Islam directs Muslims to abide by justice in all circumstances. It allows access to all people to legal courts and directs the rulers to provide justice to all the members of the society without any discrimination. 
Equality of Opportunities

Islam by prohibiting interest gives the underprivileged people chance to earn their living. A rich man in a capitalist economy will remain rich by investing his wealth to earn interest. Islam by prohibiting interest eliminates the economic and social divide between the rich and the poor. Yet it does so in a justifiable manner rather than forcing the incomes of all people to become equal artificially as in socialism.

\section{No Gender and Ethnic Discrimination}

In Islam, all the persons black or white, male or female are entitled to an equal amount of remuneration for an equal quality and quantity of work. Whereas, even in capitalist countries, there is huge income inequality between the incomes of blacks and whites and males and females. 


\section{Chapter 5}

\section{ISLAMIC FISCAL POLICY}


The role of government in an economy has always been an important issue among economists and policy makers. Economic order sans Government has not appeared in reality in any part of the world throughout the known economic history. At the least, its role as a regulator is however accepted even in a free market economy. In a Keynesian framework though, it has been placed at the center by acting not only as a regulator, but also as an active economic player.

In the midst of Great Recession, the role and importance of government has once again reappeared as an important issue. Indeed, when one looks at the bailout package of U.S government to its financial sector in December 2008 and also to its producing sector later on while also providing huge subsidies to its agricultural sector right throughout the last decade, the government's role is far from being considered minor. In an interest free economy, the key question is that how the broad based development would be achieved let alone reducing fiscal deficits.

In this backdrop, this chapter takes on important issues in public finance in an Islamic economy. More specifically, it analyzes the sources of tax and non-tax revenue for the government, sources of financing for the government and means of pricing capital in public finance.

\section{Islamic System of Zakah}

In conventional economics, the government has following sources of tax revenue: General Sales Tax, Excise Tax, Custom Duty, Import Duty, Export Duty, Octri Tax, Property Tax, Wealth Tax, Development Surcharge, Personal Income Tax, Corporate Income Tax, WHT etc. In conventional economics, government can earn through non-tax sources by way of earning through the profitable operations of State Owned Enterprises (SOEs) in public sector. Fines and activity based charges and duties are also an important source of revenue for the government. In conventional economics, if a government needs to finance deficit, it can issue Treasury Bills/Bonds or obtain loans bilaterally or multilaterally. Some governments have gone beyond issuance of Treasury bonds in the local market to issue sovereign bonds in the international market.

In an Islamic economy, the problem comes in the issuance of debt (due to prohibition of interest) and imposition of taxes. In an Islamic economy, as we discuss later, imposition of tax beyond Zakah is not recommendable. Zakah is a combination of a net worth tax and production tax.

Zakah is a religious obligation to pay a part of wealth and production to the government. However, in most countries, Zakah is not collected by the government and is not considered a compulsory payment (Powell, 2009). Respected Muslim scholar Ab-ul-ala Maududi (1970) reasoned that Zakah is a religious obligation and is not a substitute of tax. Taxes other than Zakah can be imposed in an Islamic economy if these taxes are levied by the legislative council and used for public welfare. He reasoned that the taxes discouraged in Ahadith are those which were imposed by autocratic kings for their own lavish consumption and this kind of usurpation of public property was discouraged. 


\section{Proposal for Islamic Economic Framework}

Discussing the issue of distributing Zakah, Islahi (1985) and Qardawi (2000) explained that it is not necessary to make some living person the owner of the Zakah. Zakah can be given to any person or cause or an organization working for a cause. It is not necessary to make some living person the owner of the Zakah.

Mannan (1986) opined that Zakatable goods can be modified as did Hazrat Umer (rta) who levied Zakah on horses; whereas, horses were exempt from Zakah before him. He also noted that since Zakah is a religious obligation, it would result in low tax evasion in the opinion of the author. He argued that Zakah could be distributed on the welfare of the people as well as given to people themselves. He further wrote that if a policy of full employment requires high MPC; then, a progressive taxation like Zakah could help in boosting aggregate demand and increasing employment.

Elaborating the legal importance of Zakah, Liam (2002) reasoned that property rights are valid in a post-tax environment i.e. one obtains the right to own property in the eyes of law when one pays the taxes due. Consistent with logic and this economic philosophy, property rights in Islam are also valid in a postZakah context.

Discussing modern day problems in estimation of Zakah, Usmani (2003) asserted that Zakah on shares would be paid on net liquid assets/share i.e. by excluding from the total assets, the value of assets used as means of production. From the resultant, the liabilities owed to the business are deductible. Then, the Zakah can be paid on the value of net liquid assets/share multiplied by number of shares held by the investor.

Next, we give a brief account of literature review on the institution of Zakah in Caliphates' times. Kuran (2003) identified that the application of Zakah was never uniform even in the period of Prophet Muhammad (P.B.U.H) and pious Caliphates (rta). In Umer (rta) and Abu Bakar (rta) period, Zakah was collected by the government, but, in Usman (rta) period, people were allowed to pay Zakah privately. Horses were exempt from Zakah in Prophet's time, but, Umer (rta) brought it in the Zakah net in His period. Similarly, Mahmud (2001) argued that institution of Zakah is flexible to a certain degree as Umer (rta) levied Zakah on horses and skins and at the time when Arab was hit with a drought and famine, he exempted poor from Zakah and suspended Zakah from the rich.

The collection of Zakah was centralized initially and then it was decentralized in the period of Usman (rta). Usman (rta) also levied Zakah on the production in forests (Nadvi, 1996). It has to be appreciated here that such modifications point to the flexibility that one can use to maximize the benefits of Zakah system rather than pointing to inefficiency or non-uniformity in the system. This flexibility makes the system more adaptable and applicable than rigid with limited scope for flexibility.

Kuran (2006) in another work stated that since traditional understanding on Zakah excludes industrial production and services sector from the net of Zakah, it can hardly achieve anything substantial from agriculture sector. His arguments 
are noteworthy as the share of agriculture in GDP is declining in developed as well as developing countries and it is a sector with huge documentation problems in developing countries. He also mentioned that Zakah rates are very low to have any impact i.e. $2.5 \%$ to $20 \%$. He also identified few anomalies in the Zakah system. For instance, the trader has to pay Zakah on tradable inventory, but the manufacturer is exempt from paying Zakah on means of production. Furthermore, minerals like gold and silver are taxed at $2.5 \%$, while other minerals are taxed at $20 \%$.

It is to be noted that the amount on which tax is levied is more important than the tax rate. A small percentage levied on a gross income would still ensure substantial revenue. Government would have the flexibility to allow certain deductions and not allow others. Furthermore, tax coverage, if comprehensive with low exemption amount would still result in substantial aggregate tax revenue even if marginal tax revenue from individual units (corporations as well as natural persons) is low.

Another anomaly identified by Farooq (2008) in the institution of Zakah and its common understanding is that people in livestock/dairy industry are needed to pay Zakah on cows, goats etc which are means of production for them. But, means of production in other industries are exempt from Zakah. He also stated that in Umer (rta) period, poverty diminished, but, in that period, the ground breaking conquests brought huge resources at the disposal of the then government. Such a thing can hardly happen nowadays.

On the economics of a wealth tax, Moore (2006) disclosed that in France, the solidarity tax has caused capital flight to more wealth-friendly nations. Heckly (2004) insisted that in the current environment, capital and individuals are both highly mobile, countries are working to implement active social policies, without sending capital and the wealthiest taxpayers on the run. That is the reason why, several European countries are now discontinuing wealth tax.

This led some economists to raise questions as to how public finance would work in an Islamic economy. Some studies have shown concern over the applicability of Islamic finance principles beyond the commercial banking into the pricing of loans between countries and IFls (Reddy, 2001) and monetizing public debt (Darrat \& Bashir, 2000). In this regard, Usmani (2003) proposed issuance of GDP growth linked instruments to finance public debt.

Up to now, we have quoted those Muslim scholars who maintained that taxes can be imposed for running the affairs of the state other than Zakah and it is not the mandate of Zakah to fulfill that fiscal need.

On the other hand, Kahf (1987) tracing the history of public finance during Prophet's and Caliphate's times opined that neither the Prophet Muhammad (P.B.U.H) nor the pious Caliphates (rta) levied any tax other than Zakah even when they were aware of the taxes imposed by neighboring non-Muslim countries on their citizens. Saleem (1992) pointed out three narrations of the Prophet explaining that the government cannot levy any tax other than Zakah. 
The narrations of the Prophet explaining this rule are mentioned below:

a) There is no [legal] share [for the society] in the wealth [of people] except Zakah." (Ibni Maajah: Kitab-uz-Zakah).

b) "After you have paid the Zakah of your wealth, you have paid [all] that was [legally] required of you." (Ibni Maajah: Kitab-uz-Zakah).

c) "No tax-imposer shall enter paradise." (Abu-Daud: Kitab-ul-Khiraj).

Thus far, we have discussed issues related to Zakah which is one important and unique institution available to economic managers in an Islamic economy; Next, we discuss other alternatives for finance in an Islamic economy.

Haque \& Mirakhor (1998) classified government expenditures into i) asset creating and ii) non-asset creating. Non-asset creating activities can be financed through tax revenues. But, in asset creating activities, equity modes of financing can be used whereby financing would be generated by way of an instrument. As per their recommendation, this instrument would be priced using the formula:

$I=W_{1} W I+W_{2} P P I+W_{3} L S I+W_{4} R O G$

Where,

$\mathrm{WI}=$ World Index

$\mathrm{LSI}=$ Stock Index, a measure of market performance index based on ROE.

$\mathrm{PPI}=$ Index representing average returns on commercial participation papers.

$R O G=$ Return on government investments and project.

$\mathrm{w}_{1}, \mathrm{w}_{2}, \mathrm{w}_{3}$ and $\mathrm{w}_{4}$ are weights assigned to each variable.

However, if the resultant rate is stipulated; then, it would be including opportunity cost. Two mutually exclusive equity financed projects cannot arbitrarily set to have same returns on the basis of opportunity cost.

It can be seen from the literature review that Muslim scholars are divided on the issue of whether taxes beyond Zakat can be levied or not. Basing our analysis on the viewpoint that Zakat is the only tax that can be levied along with activity/performance based duties/charges/fees and reciprocal duties on trade as were levied by Umer (rta), we now turn to present our analysis on tax and nontax sources of revenue available in an Islamic economy and to what extent these sources identified can meet the requirements of the state.

\section{Heads of Zakah}

"Alms are for the poor and needy, and those employed to administer the funds; for those whose hearts have been (recently) reconciled (to truth); for those in bondage and in debt; in the cause of Allah; and for 
wayfarer; (thus it is) ordained by Allah, and Allah is full of knowledge and wisdom (Al-Tauba: 60)".

Zakah is paid to and can be utilized by the government in following areas:

1. Poor and needy.

2. Paying salaries to government employees.

3. Muslims who have recently come into the fold of Islam, incurring political expenditures on foreign relations, domestic relations and appeasing those who by way of receiving Zakah refrain from posing threat to the Islamic state.

4. Free those in bondage. Nowadays, paying penalty on someone's behalf if need and situation demands.

5. Compensate debtors who are in trouble.

6. In the way of Allah (e.g. defense expenditure etc).

7. For making rest houses, roads and bridges for travelers etc.

\section{Institution of Zakah: Vital Source of Public Finance in Islamic Economy}

Zakah is a religious obligation to pay a part of wealth and income to the government. Nisab on wealth was basically specified in silver. Following Hadith testify this viewpoint:

"There is no Zakah below five wasaqs of dates; there is no Zakah below five uqiyahs of silver and there is no Zakah below five camels." (Mu'atta Imam Malik, No: 578)

For calculation purposes, people used the cross rate between gold and silver and determined their nisab in gold as well. This cross rate has changed historically; that is why, we will have to resort to the original base i.e. 612 grams of silver when there is no bimetallic monetary standard in operation nowadays. One important implication of this principle is that tax exemption amount in silver is much lower than gold using current cross rate and hence taxable assets will increase in magnitude. Zakah would be levied as per the ceiling rates defined for each category of wealth or production.

The classification is as follows:

a) $2-1 / 2 \%$ on cash, wholesale value of held for trade inventory and capital in excess of need payable once a year at a particular set date.

b) $5 \%$ on production using both labor and capital. It is charged at the completion of the production process.

c) $10 \%$ on production using either labor or capital. It is charged at the completion of the production process.

d) $20 \%$ on production using neither labor nor capital. This is applicable on treasure or any other natural gift obtained without using neither labor nor capital. 
To estimate Zakah on wealth, the following model is established:

Where

$$
Z R=0.025\left[Z A-\left(\text { MNA } \times P_{\text {MNA }}\right]\right.
$$

$Z R=$ Potential Aggregate Zakah Revenue

$Z A=$ Potential Aggregate Zakatable Assets

$\mathrm{MNA}=$ Minimum Nisab Amount i.e. market value of 612 grams of silver

$P_{\mathrm{MNA}}=$ People with Minimum Nisab Amount

Zakatable assets include all assets above the value of nisab except the assets in personal use and means of production. Minimum Nisab Amount is the market value of 612 grams of silver. Population with minimum nisab amount is to be estimated looking at wealth distribution of population.

On the surface, it can be seen that as Zakatable assets increase, Zakah revenue increases. Minimum nisab amount in silver terms would remain constant, but its value in currency would change. But, the effect of inflation would impact almost all endowments of an individual overtime.

\section{Issues in Estimation of Zakah}

Wealth/Assets subject to Zakah include Cash in hand, Cash in Bank, gold and silver not in daily usage (for women), gold and silver owned by men, held-for trade inventory, property/plot purchased for the purpose of resale.

Production is not limited to agriculture nowadays, but the major part of it is coming from industries as well as services sector. Therefore, industrial production could also be taxed just like agriculture. Services income could also be taxed on the same principle.

Khan (2005) stated that investment in stocks should be interpreted as any other investment with some means of earning income (See Appendix 1). Stock is a means of earning dividend or capital gains. Just like means of production/income are exempt from Zakah, investment in stocks should be exempted from Wealth Zakah as investment in stocks means that the money is not kept idle rather it is invested and even its value could reduce to zero or increase by a long way theoretically. Therefore, any income arising from investment in stocks i.e. capital gains or dividend must be subject to Income Zakah. Similarly, this argument could be extended to introducing Income Zakah on mutual funds, investment in NSS, debentures, bonds etc.

Furthermore, if land/building/house is leased, the land/building/house becomes the means of earning rent. Hence, income Zakah could also be introduced on rental income on houses, assets, buildings etc. 


\section{Estimation of Zakah}

As can be seen from Table 8, Zakah collection and its disbursement is very low and it has not been able to bring about a major socio-economic change. In FY 2009, approximately PKR 150 Billion were paid by people in Pakistan in charity, $90 \%$ of which was for the purpose of paying Zakah. (Dawn, September 07, 2009).

Table 8: Total Zakah Disbursement in FY 2007-08

\begin{tabular}{|l|c|c|c|c|c|c|}
\hline & Punjab & Sindh & NWFP & Balochistan & ICT & $\begin{array}{c}\text { Northern } \\
\text { Areas }\end{array}$ \\
\hline Regular Zakat Programmes & 1857 & 395 & 411 & 41 & 23 & 38 \\
\hline Total beneficiaries & 995 & 205 & 94.175 & 31 & 12 & 32 \\
\hline Other Zakat Programmes & 738 & 16 & 148.881 & 5 & 3 & 5 \\
\hline Total beneficiaries & 288 & 38 & 69.868 & 9 & 5 & 10 \\
\hline National Level Schemes & 196 & 83 & 62.527 & 30 & 35 & 0 \\
\hline Total beneficiaries & 93 & 60 & 31.071 & 19 & 14 & 0 \\
\hline Total amount disbursed & $\mathbf{2 7 9 1}$ & $\mathbf{4 9 5}$ & $\mathbf{6 2 3}$ & $\mathbf{7 7}$ & $\mathbf{6 1}$ & $\mathbf{4 3}$ \\
\hline \\
Total beneficiaries & $\mathbf{1 3 7 6}$ & $\mathbf{3 0 4}$ & $\mathbf{1 9 5}$ & $\mathbf{5 9}$ & $\mathbf{3 1}$ & $\mathbf{4 2}$ \\
\hline \\
Grand Total Amount Disbursed (Rs. Million): \\
\hline
\end{tabular}

Source: Ministry of Religious Affairs Zakat and Ushr.

Going into estimation of potential Zakah from agriculture produce, we first present some data that gives us an idea of how much Zakah could be collected both with present production and with enhanced production due to efficient utilization of land.

It can be seen from the following data that 9.13 million hectares are unutilized cultivable land in Pakistan. If agriculture's share is $21 \%$ of GDP utilizing 22.76 million hectares, an addition in production through utilization of that idle farm land can be computed assuming constant returns to scale on average. 
Proposal for Islamic Economic Framework

Table 9: Land Utilization (Million Hectares)

\begin{tabular}{|c|c|c|c|c|c|c|c|c|c|c|}
\hline $\begin{array}{c}\text { Fiscal } \\
\text { Year }\end{array}$ & $\begin{array}{c}\text { Total } \\
\text { Area }\end{array}$ & $\begin{array}{c}\text { Reported } \\
\text { Area }\end{array}$ & $\begin{array}{c}\text { Forest } \\
\text { Area }\end{array}$ & $\begin{array}{c}\text { Not } \\
\text { Available } \\
\text { for } \\
\text { Cultivation }\end{array}$ & $\begin{array}{c}\text { Culturable } \\
\text { Waste }\end{array}$ & $\begin{array}{c}\text { Current } \\
\text { Fallow }\end{array}$ & $\begin{array}{c}\text { Net } \\
\text { Area } \\
\text { Sown }\end{array}$ & $\begin{array}{c}\text { Total } \\
\text { Area } \\
\text { Cultivated } \\
\mathbf{( 1 + 8 )}\end{array}$ & $\begin{array}{c}\text { Area } \\
\text { Sown } \\
\text { More } \\
\text { Than } \\
\text { Once }\end{array}$ & $\begin{array}{c}\text { Total } \\
\text { Croppe } \\
\text { d Area } \\
\mathbf{( 8 + 1 0 )}\end{array}$ \\
\hline 1 & 2 & 3 & 4 & 5 & 6 & 7 & 8 & 9 & 10 & 11 \\
\hline $90-91$ & 79.61 & 57.61 & 3.46 & 24.34 & 8.85 & 4.85 & 16.11 & 20.96 & 5.71 & 21.82 \\
\hline $91-92$ & 79.61 & 57.87 & 3.47 & 24.48 & 8.86 & 4.87 & 16.19 & 21.06 & 5.53 & 21.72 \\
\hline $92-93$ & 79.61 & 58.06 & 3.48 & 24.35 & 8.83 & 4.95 & 16.45 & 21.40 & 5.99 & 22.44 \\
\hline $93-94$ & 79.61 & 58.13 & 3.45 & 24.43 & 8.74 & 5.29 & 16.22 & 21.51 & 5.65 & 21.87 \\
\hline $94-95$ & 79.61 & 58.50 & 3.60 & 24.44 & 8.91 & 5.42 & 16.13 & 21.55 & 6.01 & 22.14 \\
\hline $95-96$ & 79.61 & 58.51 & 3.61 & 24.35 & 8.87 & 5.18 & 16.49 & 21.68 & 6.10 & 22.59 \\
\hline $96-97$ & 79.61 & 59.23 & 3.58 & 24.61 & 9.06 & 5.48 & 16.50 & 21.98 & 6.23 & 22.73 \\
\hline $97-98$ & 79.61 & 59.32 & 3.60 & 24.61 & 9.15 & 5.48 & 16.48 & 21.96 & 6.56 & 23.04 \\
\hline $98-99$ & 79.61 & 59.28 & 3.50 & 24.52 & 9.23 & 5.35 & 16.58 & 21.93 & 6.28 & 22.86 \\
\hline $99-00$ & 79.61 & 59.28 & 3.66 & 24.50 & 9.13 & 5.67 & 16.32 & 21.99 & 6.44 & 22.76 \\
\hline $00-01$ & 79.61 & 59.28 & 3.66 & 24.50 & 9.13 & 5.67 & 16.32 & 21.99 & 6.44 & 22.76 \\
\hline
\end{tabular}

Source: Ministry of Food, Agriculture \& Livestock

Constant returns to scale are assumed as the Government of Pakistan is planning to lease this unutilized farmland to Middle East and European investors whose involvement is expected to increase productivity. Their interest in agriculture to achieve food security is evident from the Figure 14 given below:

Figure 14: Farm Race

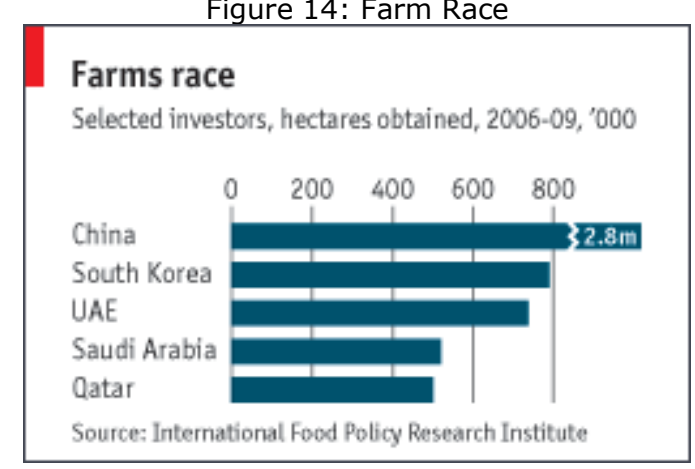

Yu-Hung (1996) revealed that Hong Kong Government captured about 39 percent of the land-value increments occurring between 1970 and 1991 from land leased in the 1970s. More importantly, the captured value financed 55 percent of the average annual infrastructure investment between 1970 and 1991. These findings indicate that land leasing can be an important source of public funds.

Next, we move to estimate potential Zakah from individuals on their wealth including Cash in bank, investments in Shares, NSS, gold deposits etc. 


\section{Calculation of Nisab for Individuals (Exemption Amount)}

Price of Silver (per oz.)

Nisab in (oz.)

Nisab value in USD

Nisab value in PKR

\section{Zakatable Assets}

\section{Bank Deposit}

Proxy of Measurement:

Data Source:

Total Banking Deposits (Rs.)

Gross Zakatable Value:

Gross Zakatable Value:
USD 15 (1 oz. = 28.34 grams)

$612 / 28.34=21.60 \mathrm{oz}$.

$21.60 \times 15=$ USD 324

$324 \times 85=$ PKR 27,540

However, total banking deposits include the money multiplier effect. The total currency in circulation is less than total banking deposits. If we take the total currency in circulation as the base for Zakah on Cash/currency, we have the following details.

\section{Currency in Circulation}

Proxy of Measurement:

Data Source:

Total Banking Deposit (Rs.):

Gross Zakatable Value:

Gross Zakatable Value:
Total Banking Deposits (Rs.)

Weekly Profile of Broad Money, SBP, March '10

PKR 5,137.219 Billion

2.5\% x PKR 5,137.219 Billion

PKR 128.430 Billion

Import Duty

Proxy of Measurement: Total Imports in 2008/09

Data Source:

Total Currency in Circulation in FY10 (Rs.)

Weekly Profile of Broad Money, SBP, March '10

PKR 1,152.173 Billion

2.5\% x PKR 1,152.173 Billion

PKR 28.804 Billion

Imports (USD):

Rationale for Levy:

FBS

USD 34.822 Billion

Umar (rta) imposed it 10\%; so leviable. ${ }^{3}$

Gross Zakatable Value: $\quad$ 10\% x PKR 2.96 Trillion = PKR 296 Billion

Gold

Proxy of Measurement:

Data Source:

Total Gold Deposit in Pakistan:

Gold Deposit at SBP (Rs.):

Price of $10 \mathrm{~g}$ Gold:

Gold in Private Hands

World Gold Council

65.4 Tons

PKR 157.544 Billion ${ }^{4}$

PKR 30,000

\footnotetext{
${ }^{3}$ Umar (rta) levied import duty on foreign goods imported into the Islamic state.

${ }^{4}$ As on June 2009 (Source: Analytical Accounts, State Bank of Pakistan).
}

(C) All Copyrights Reserved by Islamic Economics Project 
Price of $1 \mathrm{Kg}$ Gold:

Value of Total Gold Deposit:

Value of Total Gold Deposit held Privately:

Gross Zakatable Value:

Gross Zakatable Value:
PKR 3 Million

PKR 196.2 Billion

PKR 38.656 Billion

$2.5 \% \times$ PKR 38.656 Billion

PKR 0.96 Billion

$\underline{\text { Agricultural Income/Produce }}$

Proxy of Measurement:

Data Source:

GDP (Rs.):

Agricultural Income:

Zakat Rate Used:

Gross Zakatable Value:

Added Income with farm-lease:

Additional Zakatable Value:

Total Zakat from Farm Income:
Agricultural Income's share in GDP Budget Report FY08/09, FBS, CBR PKR 14,972 Billion 21\% x PKR 14,972 Billion=PKR 3144 B $80 \%$ land is irrigated $\& 20 \%$ land is rain-fed $0.8 \times 0.05 \times 3144+0.2 \times 0.1 \times 3144=189 \mathrm{~B}$ $(9.13 / 22.76) \times 3144=1,261$ Billion $0.05 \times 1,261=63.05$ Billion PKR 252 Billion

\section{$\underline{\text { Services Income }}$}

Proxy of Measurement:

Data Source:

GDP (Rs.):

Services Sector Income:

Gross Zakatable Value:

$\underline{\text { Industrial Income }^{5}}$

Proxy of Measurement:

Data Source:

GDP (Rs.):

Industrial Sector Income:

Gross Zakatable Value:
Services Income's share in GDP Budget Report FY08/09, FBS, CBR PKR 14,972 Billion 53\% x PKR 14,972 Billion=PKR 7935 B $0.1 \times 7935=793.5 \mathrm{~B}$
Industrial sector's share in GDP Budget Report FY08/09, FBS, CBR PKR 14,972 Billion 26\% x PKR 14,972 Billion=PKR 3893 B $0.1 \times 3893=389.3 \mathrm{~B}$

Next, we have to make an estimate of how many people have the wealth from various sources mentioned above exceeding Nisab Amount. For instance, if we assume that 10 million people in Pakistan have the wealth exceeding Nisab amount; then:

$P_{\text {MNA }}=10,000,000$

$P_{\text {MNA }}=10,000,000$

MNA = PKR 27,540 (as calculated above)

$Z A=$ Total Currency in Circulation + Total Gold in Private Hands

${ }^{5}$ The tax would be levied as a VAT (Value Added Tax).

(C) All Copyrights Reserved by Islamic Economics Project 
$Z A=1,152.173$ Billion +65.2 Billion $=1217.373$ Billion

From $\mathrm{ZA}$, we deduct the product $\left[\mathrm{P}_{\mathrm{MNA}} \times \mathrm{MNA}\right]$,

$\mathrm{P}_{\mathrm{MNA}} \times \mathrm{MNA}=275.4$ Billion

$N Z A=1217.373-275.4$

NZA = 941.973 Billion

We formulated the equation to estimate Zakat as follows:

$\mathrm{ZR}=0.025\left[\mathrm{ZA}-\left(\mathrm{MNA} \times \mathrm{P}_{\mathrm{MNA}}\right]\right.$

ZR $=0.025 \times$ [941.973] Billion

$\mathrm{ZR}=23.55$ Billion

Total Potential of Zakat from wealth

Total Potential of Tax from Import Duty

Total Potential of Zakat from Agriculture Produce

Total Potential of Zakat from Services Sector Produce

Total Potential of Zakat from Industrial Produce

Total Potential of Zakat \& Import Duty

Total Taxes in FY09 $=1,157$ Billion

Zakat/GDP Ratio
$=23.55 \quad$ Billion

$=296 \quad$ Billion

$=252 \quad$ Billion

$=793.5 \quad$ Billion

$=\underline{389.3 \quad \text { Billion }}$

$=1754.35 \quad$ Billion

$=11.71 \%$

It is to be noted that the estimate has not included Zakah on real estate held for trade and on held-for trade inventory. It could also not include potential Zakah coming from Capital Gains Tax on Real Estate, Stocks and Mutual Fund Units and on lease income. It has also been assumed that total receivable and total liabilities for individuals are same on average. It implies that there is no effect of receivables and payables.

Kahf (1987) mentioned that once the uncle of Prophet Muhammad (P.B.U.H), Abbas (rta) paid Zakah in advance for two years and that was in the knowledge of Prophet Muhammad (P.B.U.H). This provision can greatly facilitate the liquidity and financing needs of the state in an Islamic economy even in modern times. 
Other than Zakah, stamp duty can be levied which is a tax on documents before they become legally effective. Toll Tax can also be levied to fund the development of roads and infrastructure. In developing industrial zones, export processing zones and developing necessary infrastructure, the government can charge a licensing fee from the industrialists to fund expenditure on development. Such a tax/fee or charge is not against the Islamic injunctions as it is directly linked with provision of services and performance. It is also effective in funding expenditure on producing public goods as voluntary payments on public goods are economically ineffective. Excise tax on activities and operations creating negative externality can also be levied. This will be a cost paid to the society for meddling with natural environment.

Tax Increment Financing could also be used which is a tool to use future gains in taxes to finance current improvements which will create the conditions for those future gains. Johnson and Mann (2001) explained that when a public project such as a road, school, or hazardous waste cleanup is carried out, there is often an increase in the value of surrounding real estate and new investment. This increased site value and investment sometimes generates increased tax revenues. The increased tax revenues are the "tax increment." Tax Increment Financing dedicates tax increments within a certain defined district to finance debt issued to pay for the project. This tool is widely used in U.S and in Europe.

Adam Smith in his monumental work "An inquiry into the nature and causes of wealth of nations" gave cannons of taxation. The proposed Zakah based taxation system goes very well with Adam Smith's cannons of taxation. It has a proportional tax which can be maneuvered to be progressive as well. It does not tax production heavily (i.e. lenient tax rates) which is in line with Smith's assertion that production must not be taxed heavily. It is simple and certain. It is convenient to collect, more so because it is a religious obligation than just involuntary wealth fetching tool. It only taxes those who have ability to pay i.e. it does not tax those who do not reach a minimum threshold of wealth in their hands or those who do not produce or earn income.

\section{Economic Results of Islamic Fiscal Reforms}

1. It will help to reduce the gap between rich and poor. Expansion by way of functional inequality can very easily lead to inflation and further exacerbate the distribution of income, wealth and resources. Expansion in production and investment influenced by fiscal incentives complimented by monetary discipline (stable exchange rates than managed currency depreciation ledinflation spiral and doing away with increasing money supply) can redistribute resources in a better way and pave way for a stable and growing economy.

2. It is a progressive system of taxation. A wealth tax would redistribute wealth and resource endowments. Production with intensive mix and use of factors of production (labor and capital) is taxed leniently at $5 \%$. Production with less intensive mix and use of factors of production (labor or capital) is taxed at a minimum of $5 \%$ to a maximum of $10 \%$. Windfall gain is taxed at $20 \%$ if it arises from neither the use of labor nor capital. 
3. It covers all heads of income including income from service industries, income from goods producing industries, agricultural income, rental income, personal income, corporate and business profits of proprietors and firms, income on financial instruments like stocks, mutual funds, REITs (both dividend and capital gain included) etc.

4. It levies a special tax on cash, cash equivalents and capital in excess of need that makes sure that the money circulates and is used in the productive activities.

5. Tax on cash and capital will force the people to invest their money in productive uses. With prohibition of interest, this money will only go in business either with the start of one's own business or equity participation in Mudarabah and stocks etc.

6. It will result in an increase in tax base because it covers all heads of income.

7. It will simultaneously benefit the taxpayers as the rates in the range of $5 \%$ to $10 \%$ are very lenient as compared to the current rates in conventional taxation system.

8. Since it is not only a state obligation but more importantly a religious obligation, it is hoped that it will not result in tax evasion.

9. It reduces confinement of wealth in few hands. The flow (income) and the stock (wealth) both are taxed.

10. Including the amount of liability and receivables in Zakah accounting would encourage spot and cash transactions whenever possible and decrease the size of credit transactions.

\section{Fiscal Reforms and the Fiscal Deficit}

Pakistan's fiscal deficit is around 6\% of its GDP. The current tax to GDP ratio is approximately $10 \%$ of the GDP. It suggests that if tax-to-GDP ratio can be increased to more than $15 \%$, the fiscal deficit will substantially reduce. Zakah at rates of $5 \%$ to $10 \%$ on all production will result in the tax to GDP ratio of around $8 \%$. Moreover, with the removal of interest expense from the income statement of all enterprises, the taxable income of all enterprises will increase, resulting in an increase in tax collection.

In the system of Zakah, the tax exemption amount is very low on cash and capital in excess of need i.e. 612 gram silver which results in increase in taxable income and tax collection. The $2-1 / 2 \%$ wealth tax on cash and capital in a country will be adequate enough in attaining the total Zakah/GDP ratio of more than $20 \%$

Moreover, such a lenient taxation structure will itself increase productive activities, employment generation on a large scale and higher tax collection for 


\section{Proposal for Islamic Economic Framework}

the government. It will allow the government to allocate more resources on development.

The presence of an active public sector is required to achieve the social targets that cannot be achieved through the private sector. The income from those public enterprises will not only put a check on the private sector but also achieve the social objectives, such as reducing inequality of income. Industry specific studies can be undertaken to determine which industries must be kept in public sector and which must be privatized. Since the fiscal incentives are attractive enough to lure foreign investors, they can be asked to buy at least one loss incurring public enterprise with a cash cow enterprise. A hefty license fee can be charged to generate fiscal space for subsidizing the public sector enterprises and turning them around.

A Natural Monopoly provides an important necessity to masses. We call it natural because of the peculiar nature of that industry which requires heavy capital expenditure. Now, when more firms enter a market, market share gets divided, but not the capital expenditure. For that capital expenditure to be recovered, a firm needs volume and economies of scale. Therefore, market in that situation "naturally" needs to be concentrated.

When a Natural Monopoly is privatized, the market at best can be oligopolistic. There is no problem with oligopolistic markets in usual if the demand for the products is elastic. But, if it is inelastic, as is the case for products of a Natural Monopoly, the oligopoly would run into cartelization or by the application of game theory would again turn into a monopoly. The size of the pie can hardly be increased because the demand is inelastic. Since the demand is inelastic, the decrease in price will decrease revenue and not increase it assuming that the products are not exportable i.e. market size cannot be increased.

Therefore, competition in such a market may not depress prices, it will (even if number of firms increase in short run) result in exit of firms to once again make market oligopolistic. But, the market will not be stagnant as an oligopoly as the demand is inelastic, it will either result in cartels or in monopoly after firms try to predict other firms' behavior and make strategic choices. That is why, a Natural Monopoly exists in industries which produce an important necessity, but require heavy capital expenditure.

Privatization of a natural monopoly in "developing countries" raises few questions as in most developed countries; there is less inequality in infrastructure, income, wealth, job opportunities than developing countries in South America, Africa and South Asia. Therefore, in developed countries, the whole operations can be subdivided and sold in pieces to individual companies. But, in a developing country like Pakistan, hardly anybody would be willing to buy an electric company in NWFP and Baluchistan where line losses and significantly different infrastructure facilities, law and order situation and dispersed population exists. Therefore, operations of a giant big Monopoly cannot be easily divided and sold 
in pieces. Some can be sold, but not all divisions can be sold. If government takes over those pieces, then it will be more inefficient with less profitable business divisions than having all mixed up in one big corporation. In addition to that, a Natural Monopoly can adjust losses from one with profits from another division. It can fulfill deficiencies internally. If some divisions remain unsold, the less profitable divisions will have to fill the gap paying the market price than just a mere transfer of shortfall from one division to another as in Natural Monopoly. This will further increase the gap between profitable and less profitable divisions and eventually it will once again become a consolidated industry and may even become a monopoly.

In that case, a Natural Monopoly is better off being in Public ownership and hence the concept 'Public Monopoly'. The only thing forgone is tax revenue. But, it comes if it is profitable. If it is profitable, then, profits do overcome taxes. Tax revenue cannot be greater than profits (since we are assuming direct taxes). Further, the government avoids regulation. Moreover, in developing countries, this huge capital expenditure would usually be provided by foreign companies. They can repatriate profits and hence will increase capital flight.

In other cases, we can give private sector the chance to lead the economy. In the proposed model, Defense, Communication, Transport, Education and Health would be run in Public sector as is the case in most other countries too. In other sectors, government can either privatize or give operating rights to private sector and retaining ownership to some extent.

Privatization would increase layoffs and increase structural unemployment. Structural unemployment is classified as natural in Economics. The government is only responsible to avoid cyclical unemployment. Structural unemployment requires education to be in Public sector and subsidized. Scandinavian and many European countries have an efficient public sector education system. It is subsidized and it needs to be subsidized to enable people to change their fortunes after structural unemployment. In the time lag between the change of fortunes, they also need subsidized health facilities and hence health should also be in public sector. Private education system and health can run in tandem with public sector. But, some education and health must exist in public sector.

One possible question may arise here as to how such lenient tax rates would increase substantial revenue. If the government has a fiscal deficit of $6 \%$ of GDP when corporate tax rates are $35 \%$; then, how can reducing tax rates increase the revenue?

The answer to this is given by the Laffer curve in Figure 15 . 
Figure 15: Laffer Curve

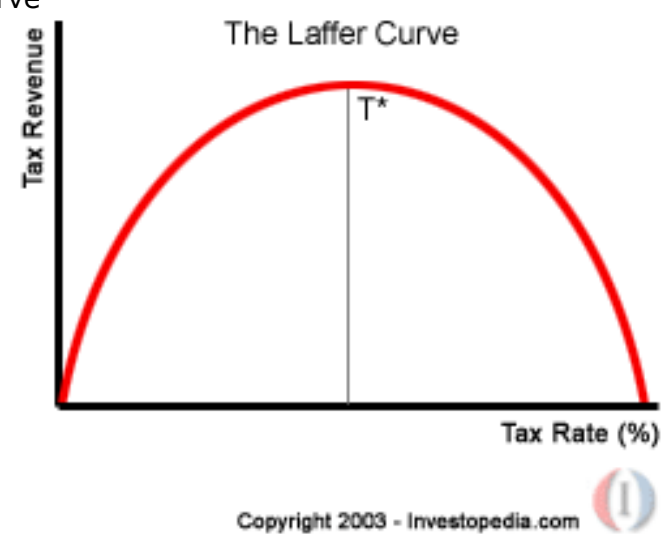

Higher tax rates discourage entrepreneurship as they decrease the incentive to produce. Lower tax rates encourage entrepreneurship and hence increase the size of producing sector and hence production. With the increase in production, tax revenue in amount increases. Lower tax rates can still ensure high tax to GDP ratio. This is evident from Table 10 which lists countries with corporate tax rates below $20 \%$ and their tax to GDP ratio.

Table 10: Corporate Tax Rate \& Tax to GDP Ratio

\begin{tabular}{|c|l|c|c|}
\hline S.No. & \multicolumn{1}{|c|}{ Country } & Tax to GDP Ratio & Corporate Tax Rate \\
\hline 1 & Chile & $17.1 \%$ & $17 \%$ \\
\hline 2 & Bulgaria & $34.4 \%$ & $10 \%$ \\
\hline 3 & Czech Republic & $36.3 \%$ & $21 \%$ \\
\hline 4 & Georgia & $21.7 \%$ & $15 \%$ \\
\hline 5 & Greece & $33.5 \%$ & $22 \%$ \\
\hline 6 & Hong Kong & $12.8 \%$ & $16.5 \%$ \\
\hline 7 & Hungary & $37.3 \%$ & $16 \%$ \\
\hline 8 & Iceland & $40.4 \%$ & $18 \%$ \\
\hline 9 & Ireland & $34 \%$ & $12.5 \%$ \\
\hline 10 & Kazakhstan & $26.8 \%$ & $15 \%$ \\
\hline 11 & Netherlands & $39.5 \%$ & $20 \%$ \\
\hline 12 & Poland & $33.8 \%$ & $19 \%$ \\
\hline 13 & Romania & $28.1 \%$ & $16 \%$ \\
\hline 14 & Russia & $36.9 \%$ & $20 \%$ \\
\hline 15 & Serbia & $34.1 \%$ & $10 \%$ \\
\hline 16 & Singapore & $13 \%$ & $17 \%$ \\
\hline 17 & Slovakia & $29.5 \%$ & $19 \%$ \\
\hline 18 & Switzerland & $30.1 \%$ & $13 \%-25 \%$ \\
\hline 19 & Turkey & $32.5 \%$ & $20 \%$ \\
\hline 20 & Uzbekistan & $21 \%$ & $12 \%$ \\
\hline
\end{tabular}

Source 1: International Tax \& Business Guides- Economic Data - Statistics - Tax - EIU The Economist 
Source 2: 2009 Index of Economic Freedom - Heritage Foundation

If this system is enforced with utmost sincerity by the government, along with the commitment of the general public and the public/private sector partnership, this can put an end to deficit financing. It will automatically result in price stability and improvements in living standards.

\section{Effects of Fiscal Policy on Property Market}

If the tax (Zakah) program is implemented as proposed, there will be a $10 \%$ income tax on the proceeds of sale of a property. The tax will be more if the property is kept than when it is sold. This will increase the supply of land that was not presented for sale before. The increase in supply will bring the prices of properties down. Hence, affordable housing and commercial facilities i.e. office premises, factories etc will come in the reach of consumers and commercial enterprises respectively.

A simplified model is presented below:

\section{Property value at $t_{0}: 1,000,000$}

Property Prices increase at $t_{1}$ by $10 \%: 1,100,000$

If property kept at $t_{1}, 2.5 \%$ tax on property: 27,500

If property sold at $t_{1}, 10 \%$ tax on Gain $: 10,000$

Net Tax Gain: 17,500

If the property owner does not want to sell the asset and use it in future, but still wants to benefit from the fiscal incentive, he can give it on rent. It will be considered an investment and hence instead of wealth tax, income tax will be charged. $10 \%$ income tax will be charged on rental income.

A simplified model is presented below:

$$
\text { Property value at } t_{0}: 1,000,000
$$

If property given on rent @10\%/year of property value

If property kept at $t_{1}, 2.5 \%$ tax on property: 25,000

If property rented until $t_{1}, 10 \%$ tax on Rent: 10,000

Net Tax Gain: 15,000 


\section{Effects of Fiscal Policy on Investment}

Government will not be able to achieve growth all by itself. The fundamental nature of the economy proposed here is modified capitalism with free market principles with social responsibility and ethical checks. Therefore, private sectors including both local and foreign investors have an essential role to play in achieving the desired growth and development targets. The goal is not only to redistribute the pie, but to increase the pie is well.

The maximum corporate tax rate ceiling of $10 \%$ will decrease the tax expense and free more resources for reinvestment and profit distribution among shareholders i.e. dividend. Since the proposed economic framework is holistic, the monetary policy effect of discontinuing interest-based products will make savers go for equity investments and the whole economy will gradually transform from debt-based financing to equity-based financing.

Dealing with risk averse investors is also a major issue. Here, the credit rating agencies will have a big and active role to play in providing timely information and fact based forecasts. However, what will make it all possible is the massive inflow of $\mathrm{FDI}^{6}$ because of tax advantage. This will increase the competition and convert the major oligopolistic ${ }^{7}$ industries into more competitive industries. Therefore, sectoral diversification will be possible for risk averse investors.

It can be seen from fiscal models presented above that if any form of wealth i.e. property, fixed asset, cash etc is put into investment, its nature for fiscal treatment changes and tax saving of at least $2.5 \%$ results on the gross investment i.e. if there is no income on investment, $2.5 \%$ tax saving results and no income tax is paid since there is no income.

Competition makes the market more efficient than what the government intervention can do. Therefore, provided with fiscal incentives, investment both local and foreign is expected to increase, bringing more employment, making industries competitive and hence more responsive to their stakeholders i.e. customers and shareholders.

\section{Effect of Fiscal Policy on Equity Markets}

With interest-based deposits discontinued, savers will have to make a choice between keeping their money idle and pay wealth tax or invest it in some asset and pay the tax only on income if it is earned.

A simplified model is presented below:

\footnotetext{
${ }^{6}$ FDI: Foreign Direct Investment

${ }^{7}$ Oligopolistic markets are markets in which there are few sellers rather than a single seller as in monopoly or many sellers as in perfect competition and monopolistic competition.
} 


\begin{tabular}{|c|c|}
\hline $\begin{array}{l}\text { Value of Stock of Com } \\
\text { Stock Prices increase }\end{array}$ & $\begin{array}{l}\text { A at } t_{0}: 100 \\
\text { oy } 10 \%: 110\end{array}$ \\
\hline $\begin{array}{l}\text { If no investment in stock or other assets } \\
\text { If stock sold at } t_{1}, 10 \% \text { tax on Gain on Sale }\end{array}$ & $\begin{array}{l}: 2.75 \\
: 1\end{array}$ \\
\hline Net Tax Gai & \\
\hline
\end{tabular}

If the shareholder does not want to sell the stock, but still wants to benefit from the fiscal incentive, he can keep and pay tax on dividend. Purchase of stocks for capital gain/dividend will be considered an investment and hence instead of wealth tax, income tax will be charged. $10 \%$ income tax will be charged on dividend income.

A simplified model is presented below:

$$
\begin{aligned}
& \text { Value of Stock of Company } A \text { at } t_{0}: 100 \\
& \text { Company } A \text { is profitable \& pays } 10 \% \text { dividend }
\end{aligned}
$$

If no investment in stock or other assets

If stock kept at $\mathrm{t}_{1}, 10 \%$ tax on Dividend

Net Tax Gain: 1.75

\section{Effects of Fiscal Policy on Inflation}

The fiscal incentives provided will bring in investment from local as well as foreign investors and the discontinuation of interest based investment avenues will make equity financing by companies possible. Therefore, those commercial enterprises with own funds will come for fiscal incentives and those commercial enterprises with limited internal equity will be able to generate funds through equity financing.

It will transform the oligopolistic markets into competitive markets. Hence, firms will not have much influence to effect prices. Therefore, artificial price increases through collusion and hoarding will not be possible. The other notable driver of inflation is the interest rate. Since the interest will be discontinued, inflation will not be derived from interest. Therefore, inflation will only increase at the natural rate and its effect will not be felt by common person due to direct taxation since there will not be indirect taxes which inflate prices of inelastic goods. Furthermore, increase in investment and new entrants will increase employment opportunities and the per capita income of masses.

\section{Non-Tax Revenues}

Non-Tax Revenue can come from profitable operations of State Owned Enterprises (SOEs). State Owned Enterprises (SOEs) in postal services, 
railways, airline industry, steel industry, communication industry, public utilities, transportation industry, aviation industry etc can be run effectively and generate profits as they operate in industries which have significant potential for economies of scale, economies of scope and face relatively inelastic demand. With deficit financing not an option available, there will be an automatic check on government to run these State Owned Enterprises (SOEs) effectively and efficiently.

Fines and Penalties is another source through which government will generate funds. Ideally, this is not a source of revenue as the objective of fines and penalties is to enforce law, improve competition and put right market imperfections. But, this will materialize only when the good practices are rewarded and bad practices penalized.

\section{Funding Non-Revenue Generating Activities}

The real problem arises in funding operations of non-revenue generating activities like the operations of courts and police etc. It is to be noted here that in Muslim societies under the rule of Caliphates, there was no concept of jail which is a later invention. The Islamic punishments like Capital punishment on Murder, Forced Rape etc, monetary fines and physical punishment in extreme cases of stealing, fraud, robbery etc do not require people to be imprisoned. As a matter of fact, these prisons become the nurseries for bringing societies even more seasoned criminals rather than a place for rehabilitation. Besides the convicted person, the family of the convicted also gets heavily affected by such imprisonment.

Therefore, reforming the penal law based on Islamic principles will significantly reduce expenditure on making, developing and maintaining such prison cells. If we study the judicial system in Caliphates time, the judicial system did not have high cost of advocacy. Infact, there was no concept of $3^{\text {rd }}$ party advocacy as the law of the land was simple and its implementation enforced strictly. The society put huge emphasis on honest testimony. The judicial system was highly centralized and that too in Umar (rta) and Usman (rta) period when the Islamic state was spread all over Arabia and touching North Africa as well as Eastern Europe.

\section{Alternative for Public Finance Other Than Zakah}

Next, we discuss how the budget deficit could be financed in an Islamic economy. First of all, it is to be noted that sources of revenue (tax and no-tax) will be substantial enough to meet necessary development and non-development expenditure. Furthermore, if true Islamic values are adopted, non-development expenditure in providing perks to the government officials will also reduce.

Looking beyond imposing more taxes, Usmani (2003) proposed issuance of GDP growth linked instruments to finance public debt. In public finance, a Nominal GDP linked bond could be issued. 
In public projects valuation, this benchmark rate would be used to find PV of Cash Flows. This would be appropriate due to following:

i. It will not lead us into falling in time value of money as we are using an enterprise or output related benchmark rather than interest based benchmark.

ii. The Cash Flows are obtained using equity contractual modes like Mudarabah and Musharakah.

iii. In this case, we are calculating valuation models for the investor and not for the borrower. Borrower or financee will be obliged to provide the returns based on these valuations. But, the investor can use this "indicative valuation" to rank investment alternatives.

In actual distribution of income between financier and financee, profit sharing ratio would be used and agreed upon at time (t) and applied to the actual gross profit earned by the financee in time period $(t+1)$. In Figure 16, data for the period 1970-2008 for a group of big economies i.e. America, Britain, Canada, China, the euro area, India and Japan is shown on the variables Nominal Interest Rates (t) and Nominal GDP Growth Rate (t-1) since Nominal GDP responds to interest rate changes as it decreases aggregate demand for the subsequent period, a lag variable for GDP i.e. GDP (t-1) is taken.

Figure16: Nominal GDP ( $t-1)$ and Nominal Interest Rates ( $t$ ) for a group of big economies

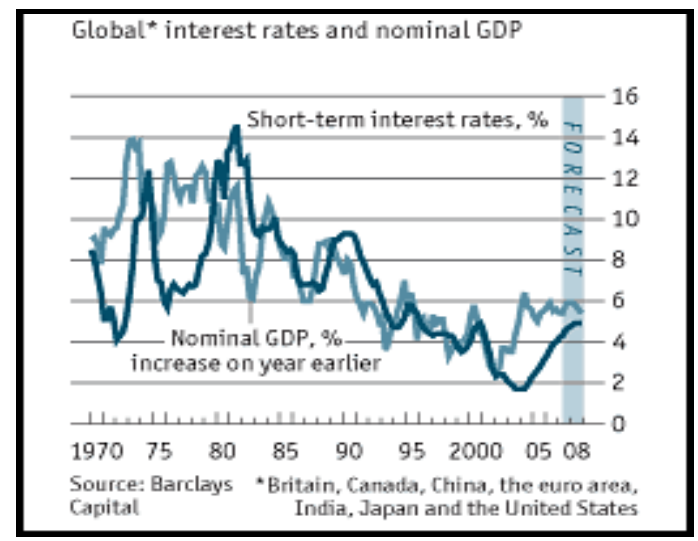

It can be seen that both variables virtually moved together throughout the period and especially since 1990. Therefore, it is plausible to use Nominal GDP growth rate as the benchmark for pricing instruments in public finance. Since this figure confirms the movement of both variables in the same directions, it can be used for indexing multilateral loans, loans between central banks and between central banks and international financial and development organizations such as IMF, WB, IDA, IDB, ADB etc.

Most developing countries are going through a perpetual debt trap which takes away resources that could have been used on development, but instead are 
used to service compounded debt. In Figure 17, it is shown that interest payments take up most of the resources of government.

Figure17: Interest expense as a \% of total government's expense

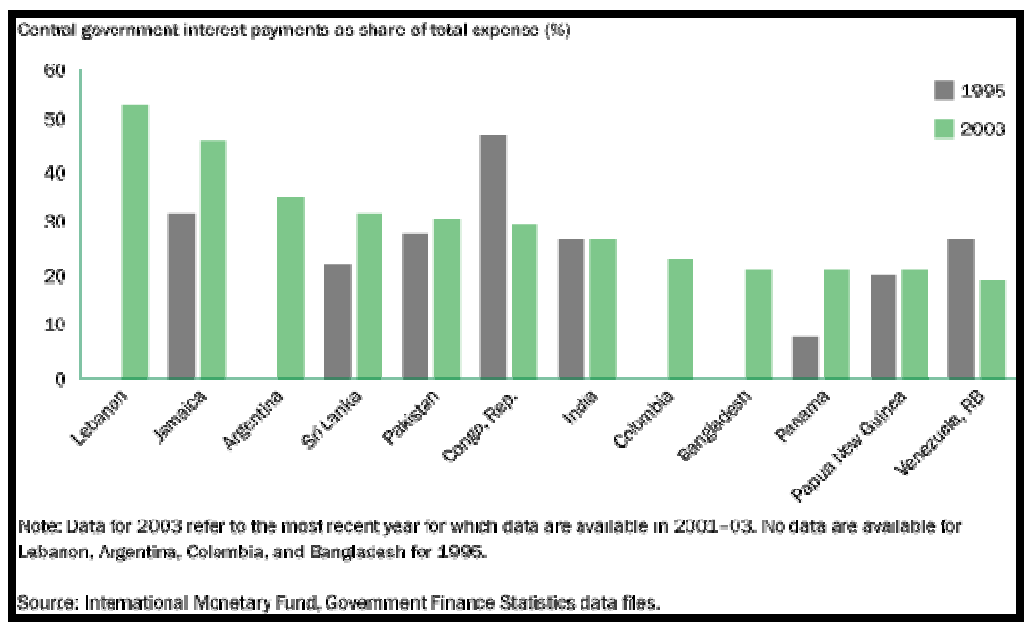

The proposed NGDP linked instrument will not only compensate the financier for parting with liquidity and capital, but also provide a stable mechanism for recipient countries to get out of debt trap with debt servicing linked with output performance benchmark and it will provide relief in the balance of payment and foreign debt management to central banks in developing countries.

Second, the government could divest its ownership in State Owned Enterprises (SOEs) or privatize some of them altogether. It could also issue new stocks of State Owned Enterprises (SOEs) and obtain funds for these corporations through primary equity markets.

\section{Conclusion}

This chapter explored the sources of revenue for a government in an Islamic economy. Though Zakah rates are low, but Zakah base is very broad and can include all productive activities. The chapter also provided brief insights into how much Zakah could be collected in Pakistan and showed that there is ample potential to reach a double digit Zakah to GDP ratio and together with non-tax revenue, the government in an Islamic economy can manage its operations without resorting to interest based deficit financing.

This chapter also discussed that the government if needed can finance its deficit by using nominal GDP growth linked rate of return as a benchmark for domestic and external loans including those from IMF, WB and IDA etc. 


\section{Chapter 6}

\section{ISLAMIC MONETARY POLICY}




\section{Salient Features of Islamic Monetary Regime}

Monetary policy guidelines extracted from the Islamic economic principles can be categorized under the following heads.

1. Interest free economy

2. Low to moderate inflation

3. Stable exchange rates

4. Increased Savings

\section{Interest Free Economy}

The proposed Islamic economic framework will be interest free. Interest will not only be removed from the banking system, but also from the economy. Fiscal incentives will encourage new entrants in oligopolistic markets and increase competition. The increased competition will depress prices to their natural level.

Furthermore, the fiscal space will also enable the government to use price discrimination $^{8}$ in giving targeted subsidies to the poor and needy.

\section{Low to Moderate Inflation}

Four of the most important drivers of inflation are interest rates, depreciation of money, indirect taxes and price distortions due to imperfect markets. As it has been discussed above that in the proposed Islamic economic framework, interest will be removed from the economy and the money supply expansion will be dependent upon productive loans disbursed. Furthermore, fiscal incentives i.e. no indirect taxes and lenient tax rates on income/production bringing new entrants will make markets competitive and bring the prices down to their efficient level. Price manipulation and output restrictions resulting in deadweight loss ${ }^{9}$ will not occur in the proposed economic framework. Hence, inflation will grow at its natural level. The goods in which certain individuals have a greater consumer surplus, the price for them can be set higher using price discrimination.

\section{Stable Exchange Rates}

Since the focus is on increased productive capacity and not on deficit financing and tax base broadening along with fiscal incentives, the value of the currency will not be sacrificed to finance the deficits. Furthermore, fiscal incentives will lure foreign investors. A handsome license fee can be charged from foreign investors to finance government deficits in the short run before the proposed economic framework starts bringing its true advantages.

\footnotetext{
${ }^{8}$ It refers to different prices charged from different customers. It is based on the concepts of consumer surplus, elasticity and diminishing marginal utility of money.

${ }^{9}$ Deadweight loss refers to a welfare loss in imperfect markets due to price/output distortions, subsidies and indirect taxes.
} 
Exchange rate stability improves if balance of payments situation improves. Balance of Payment improves if the country's exports increase at a higher rate than imports. With interest not adding to the cost, it will decrease the cost of production and hence make exports more competitive. With no interest in the economy complemented by a wealth tax, equity investment will be boosted and the firms will be in a better position to generate financing through equity mode. Hence, investment in better technology and expansion to reap economies of scale would become possible.

\section{Savings}

In the interest based monetary system, the inflation sometimes cross interest rates and the real interest rate earned on an investment goes negative. In the proposed economic framework, inflation is adequately controlled and with stable exchange rates, the return on investment will remain positive even if it is not fixed.

If interest based system can survive and induce savings even when the real interest rates are negative, there is no reason why the proposed economic framework cannot survive with all the right mechanisms in place to achieve positive return on investment. Interest rates in U.S.A reached the zero bound in December 2008.

Krugman [September 02, 2009] in his New York Times article titled "How Did Economists Get It So Wrong?" analyzed the current financial crisis and Fed's response in following words:

"But zero, it turned out, isn't low enough to end this recession. And the Fed can't push rates below zero, since at near-zero rates investors simply hoard cash rather than lending it out. So by late 2008, with interest rates basically at what macroeconomists call the "zero lower bound" even as the recession continued to deepen, conventional monetary policy had lost all traction.

Now what? This is the second time America has been up against the zero lower bound, the previous occasion being the Great Depression. And it was precisely the observation that there's a lower bound to interest rates that led Keynes to advocate higher government spending: when monetary policy is ineffective and the private sector can't be persuaded to spend more, the public sector must take its place in supporting the economy. Fiscal stimulus is the Keynesian answer to the kind of depression-type economic situation we're currently in."

The proposal presented in this book also favors fiscal expansion by way of decrease in tax rates, increasing tax base along with prohibition of interest and providing an alternative to interest based monetary system that will not have the problematic features of interest. Therefore, interest based system can be 


\section{Proposal for Islamic Economic Framework}

overtaken and the economy can be run on a sound footing provided the proposed holistic approach is taken and implemented with sincerity.

\section{Dealing with Scarcity of Capital}

Business cycles are a reality. Infact, as per Islam, they must exist as this world is a place for test and this test requires some people to be privileged and some to be deprived. The deprived and privileged are both tested for patience and thankfulness to Allah and how they take care of society and its needs. But, interest as a system of allocation of resources ensures a fixed return for one and variable/uncertain for another. That is why, business cycles affect borrowers negatively. Hence, leveraged companies thrive in upturns, but lose in downturns. Equity financing ensures justice.

Interest makes capital scarce, brings oligopoly in capital goods industries and monopolistic competition in consumer goods industries i.e. market imperfections. Market imperfections lead to mismatch between supply and demand, hence create downturns every now and then in economy. This downturn leads to monetary easing to increase Aggregate Demand, but the market remains imperfect even then because capital is still scarce with interest and no wealth tax (more prominently in developing countries with indirect taxes greater than direct taxes). If it is followed by cost-push inflation, it gives rise to Stagflation eventually. In Stagflation, monetary economics fail and further exacerbate the situation with output decreasing and capital made scarcer with increase in interest rates. Inflation can be better checked through supply chain management and removing market imperfections complimented by progressive taxation.

Business Cycles will continue to exist as they are natural, but the loss/profit would be shared. Therefore, markets will not produce speculative surplus output and that will stabilize business cycles.

Stagflation (Inflation rises and GDP growth decreases) defies both Okun's law (If GDP increases by 3\%; unemployment decreases by $1 \%$ ), Taylor's Rule [Monetary tightening by more than unity (i.e. $>1 \%$ increase in interest rates) for a unit \% increase in inflation (i.e. 1\%)] and short run Phillip's curve (inverse relationship between inflation and unemployment).

Furthermore, Inflation in U.S is down, but not entirely due to monetary policy. Food prices are down due to subsidies and energy needs of U.S are also met not entirely using market (i.e. due to political factors and influence in resource rich countries to procure resources cheaply).

Even if interest rates were decreased to below $2 \%$ in U.S, Inflation has not risen. Economists especially from Chicago School (from where Milton Friedman belongs too) analyzing Great Depression criticized Central Bank for having not adopted monetary easing and thereby worsening the sentiments. Great Depression, as we all know, occurred after Stock Market Crash. In the 'Great Recession' today, Central bank in U.S is not adopting tight monetary policy 


\section{Proposal for Islamic Economic Framework}

because inflation is tackled through non-market forces (Subsidies and Political influence in resource rich countries to meet demand at affordable prices) because U.S did not have that financial capacity nor the political influence at the time of Great Depression unlike today. But, this monetary easing has still not caused private investment and private sector borrowing to increase and the huge trade and fiscal deficit of U.S is still not causing the crowd out effect and same is the case in Pakistan after the reduction in policy rates.

Dr. Ansari (2010, p.VI) analyzing Pakistan's monetary policy statement for AprilJune 2010 issued by State Bank of Pakistan stated:

"No justification is offered for the dogma that a reduction in the 'policy rate' will enhance inflationary pressure. There is overwhelming evidence that this is not true and the near-zero interest rates in Japan, Europe and America in recent years have generated no inflationary pressure at all."

The bearish sentiments in economic downturns, as Keynes said, can only be revived by Public investment either through increasing government expenditure in public sector enterprises or by providing subsidies to private sector enterprises. No matter how hard one tries to deny it, when one considers the bail-out package for financial sector as well as producing sector in U.S and the huge subsidies provided by OECD countries to their farmers, one cannot say government has no role to play in an economy.

In the proposed economic framework, interest will be discontinued by a legal decree complimented by an imposition of broad based wealth tax (Zakah). An imposition of wealth tax (Zakah) would ensure that loanable funds increase even when there is no interest. The loanable funds would be invested in equity modes of financing including Mudarabah and Musharakah. Investments in equity will be exempted from wealth tax. This would ensure that investors get a minimum return i.e. tax savings plus income on their equity investments. This tax exemption would also ensure the availability and supply of loanable funds.

In an interest free economy, income only bonds could still be introduced. These bonds need to be serviced provided there is income. The service payments on these bonds will be tax deductible. Tax deductible feature would benefit issuer and the compulsory servicing of bond in case of income would benefit investors to invest in blue chip companies. Companies which are not in the ranks of blue chip companies would issue convertible income only bonds. Since there is a one sided promise, it will not be against any of the Islamic principles. Exemption of investment in income bonds would also ensure the availability and supply of loanable funds in income bonds market.

In the proposed economic framework, dividends will allowed to be tax deductible; thereby, benefiting the company to benefit from tax advantage and increase the frequency of dividend payments and make it a regular feature. This will further boost and compliment the availability of loanable funds. 
By discontinuing interest through a legal decree, primary market activities in equity markets will increase since companies will no longer be able to generate finance through debt. Therefore, increase in listed companies will expand the market and diversify trading opportunities for investors.

\section{Role of Central Bank in an Islamic Economy}

Interest free banking has been introduced in many Muslim countries since 1960. It has widened in scope, size, sophistication and reach ever since then. In academic literature relevant to the role and functions of central bank and monetary management based on Islamic ideals, we find concepts such as refinance ratio (Siddique, 1982), Qard-e-Hasan ratio (Khan, 1982), Mudarabah based lending between commercial and central banks and restricting high powered money by way of RRR than relying on OMO (Chapra, 1983), Time Multiple Counter Loan (Mehmood, 1991), composite stock (Zangeneh \& Salam, 1993) and central bank having equity stake in commercial banks (Uzair, 1982) to name a few. Few studies have focused on the price of capital in an interest free context using shadow price in place of the regular accounting price (Mannan, 1982) and some studies have shown concern over the applicability of Islamic finance principles beyond the commercial banking into the pricing of loans between countries and IFls (Reddy, 2001) and monetizing public debt (Darrat \& Bashir, 2000). In this section, first, a brief overview of ideological discussion on pricing capital in the literature is provided followed by practicable alternatives as suggested by Islamic economists are discussed.

Kurrihara (1951) asserted that if a central bank is the government's bank; then, if government sells securities to the central bank, interest payment paid by the government will eventually come back to the government. In his viewpoint, there might not be an economic or payoff difference.

Mannan (1982) proposed the use of accounting price of capital which will neither add to the cost of production nor form part of the profits; but, instead will be used to appraise projects.

Reddy (2001) highlighted an important problem in an interest free economy as to how it will deal with external debt management which is primarily interest based. Similar concern was shown by Darrat \& Bashir (2000) as to how deficit financing can be monetized in an interest free economy and how expectations about the rate of return can be formulated.

As can be seen from the above discussion that pricing capital in an interest free economy has been a problematic issue to deal with. Responding to Kurrihara's viewpoint, it must be emphasized that interest is prohibited in absolute sense and it cannot be accommodated even if the same transaction is reversed over a period of time and thereby nullifying the economic impact. Responding to Mannan's viewpoint, it must be highlighted that if interest is criticized on the presumption that it is not a rightful mechanism to allocate resources; then, this accounting price (or rate of profit) will be no different. However, capital rationing is still useful to avoid free-rider problem as long as an artificial and rigid scarcity 


\section{Proposal for Islamic Economic Framework}

of capital can be avoided. But, the vacuum still exists as to how to effectively price capital in a holistic way to encompass both private finance and public finance.

Now, we come to the various practicable alternatives that have been suggested to see whether the literature offers us a clue as to how capital may be priced holistically and look for various ways in which a central bank in an interest free economy can carry out its functions and roles. Chapra (1983) realizing that the two important instruments of monetary policy in the capitalist economy, discount rate and open market operations in interest-bearing government securities will not be available, he recommended following important measures for devising an alternative system of central banking in Islamic finance.

\section{i) Managing Monetary Base, Deposit Mobilization \& Fund Utilization}

Central bank should make the total Mo created by it available partly to the government and partly to the commercial banks and the specialized financial institutions. The part of Mo made available to the government should be an interest-free loan to enable the government to finance its social welfare projects. The part of Mo made available to the commercial banks should be treated as Mudarabah advances and the profits realized from these should be made available to the government to finance projects designed to eliminate poverty and reduce income inequalities. The part of Mo made available to specialized credit institutions should also be a Mudarabah advance and be used mainly for financing productive activities -of self-employed persons, farmers, cottage industries and other small businesses which, though viable and socially necessary, are unable to obtain funds from commercial banks. The government would pay actual service charge to the commercial banks who acted as agents to mobilize funds from general public. This service charge would not be Riba as it will not involve time value of money and only actual cost of mobilizing funds would be reimbursed.

\section{ii) Public Share of Demand Deposits}

A certain proportion of commercial bank demand deposits up to a maximum of, say, 25 per cent, should be diverted to the government to enable it to finance socially beneficial projects in which profit-sharing is not feasible or desirable. This should be in addition to the amount diverted to the government by the central bank for expanding the monetary base (Mo). The rationale behind this proposal is that firstly, the commercial banks act as agents of the public for mobilizing the society's idle resources; secondly, the banks do not pay any return on demand deposits; and, thirdly, the public does not bear any risk on these deposits if these are fully insured. Hence it would be fair to expect that the society's idle resources thus mobilized should be used for social benefit except to the extent to which the society permits the commercial banks to use them for private benefit in the larger social interest. One of the important ways of using them for social benefit would be to divert a part of the demand deposits thus mobilized to the public treasury to finance socially beneficial projects without imposing any interest burden on the public exchequer. 


\section{Proposal for Islamic Economic Framework}

\section{iii) Statutory Reserve Requirement}

Commercial banks should be required to hold a certain proportion, say, 10-20 per cent, of their deposit liabilities with the central bank as statutory reserves. The central bank-should pay the commercial banks the cost of mobilizing these deposits just as the government would pay the cost of mobilizing 25 per cent of demand deposits diverted to the government. This statutory reserve requirement could be varied by the central bank in accordance with the dictates of monetary policy. The rationale behind a statutory reserve requirement only against demand deposits is that the Mudarabah deposits would constitute a part of bank equity in an Islamic economy and since there is no statutory reserve requirement against other forms of equity, there is no reason why Mudarabah deposits should be subject to such a requirement.

He further highlighted the benefits of his proposal on public finance by explaining that the government's financial problems would also be solved partly because, firstly, additional interest-free resources would be made available to the government in the form of created money, and secondly, a certain proportion of all commercial bank demand deposits would also be made available to the government. This would carry a service charge which would be considerably smaller than the heavy interest burden which makes the rich richer through interest receipts and the poor poorer through additional taxes levied to service the public debt.

Siddiqui (1982) supported the use of "refinance ratio" i.e. central bank refinancing a part of the interest-free loans provided by commercial banks to influence the volume of short term credit extended by the commercial banks. Khan (1982) advocated the use of "qard-hasnah" ratio i.e. the percentage of demand deposits that commercial banks are obliged to lend as an interest free loan to influence the availability of credit.

Uzair (1982) proposed that that a central bank can acquire equity stake in commercial banking by holding $25 \%$ of the capital stocks of the commercial banks. He opined that it would give a permanent source of income to the central bank and enable it to better play its role as a lender of last resort. However, his proposal is criticized on the basis of bringing conflict of interest between regulator and private banking institutions.

Mehmood (1991) introduced the TMCL model which is based on the basic idea that in a loan arrangement, both the amount of loan and time to maturity are equally important. Thus, if the amount of any loan is multiplied by the period for which it is provided, the result would be a unit i.e. loan value (LV). Thus an amount of Rs. 1000 for one year, has the same loan value as Rs.125 for eight years i.e. both sum up to the same loan value of Rs.1,000. Therefore, any combination of giving bilateral loans whereby the loan value remains same is in conformity with Islamic principles as it will fall in the realm of Qard-e-Hasan. Therefore, if a borrower needs a loan of Rs.1,000 for one year, he can give away a loan of Rs.125 for eight years and get a loan Rs.1,000 for one year. According 


\section{Proposal for Islamic Economic Framework}

to the author, the TMCL concept could be used in interbank lending and borrowing and between central banks and commercial banks.

Zaheer (1996) criticized TMCL concept arguing that TMCL is based on the premise that money ought to have time value, the Islamic prohibition of Riba requires that money should not be allowed to have any time value at all. Consequently, the TMCL proposal is contributing to resurrect exactly the same evil which Quran wants to see condemned to extinction.

Zangeneh \& Salam (1993) presented two possible alternatives for money management i.e. alternative of discount rate and open market operations in Islamic finance. They recommended that the central bank could charge the borrowing bank a weighted average rate of return in different sectors of the economy plus or minus a discretionary premium to discourage borrowing if the economy is facing inflation. In recession, the central bank could charge the borrowing bank a weighted average rate of return in different sectors of the economy minus a discretionary discount (i.e., provide a subsidy) to encourage borrowing from the central bank. In this mechanism, the central bank would charge the borrowing bank a rate depending on the profit rate that prevails in the economy, plus or minus a policy premium or discount factor depending on the condition of the economy. At the time of providing funds, the central bank could use the last month's, last quarter's, or last year's data to calculate the relevant rate for short term borrowings of commercial banks. However, as soon as the central bank determines the actual profit rate for that particular time period, it could recalculate its share of the profit or losses, based on the agreed terms at the time resources were made available by the central bank, and charge the commercial bank for the loan or reimburse the bank for the overcharges.

Secondly, while recommending the alternative to traditional $\mathrm{OMO}$ in interest based banking, they recommended that the central bank could perform its open market operations in terms of a "composite stock" representing the central bank's ownership of all of the government and government agencies' owned enterprises. By trading a "composite stock" rather than individual private or public company's stocks, the potential problem of exerting undue influences on the price of a company's stocks is avoided.

Khan (2004) argued against elimination of interest by a legal decree and favored free market forces to bring the interest rates down to zero. He also emphasized on providing incentives for the use of equity over debt financing. He proposed following policy measures:

i) Reducing reserve requirements to increase supply of lent funds.

ii) Enforcing unlimited liability.

iii) Gradual decline in interest to make investments in debt based instruments less lucrative and shift loanable funds towards equity based instruments.

iv) Allowing dividend as a tax deductible expense.

v) Providing fiscal incentives to non-leverage firms and disincentives to leverage firms. 
These recommendations worth serious consideration, but, limited liability is only available in partnerships which as are not as common and popular forms of business organization and in corporations. Limited liability in corporation serves the interest of shareholders which are mainly individuals from general public. Limited liability solves the agency problem by acting as a check on managers to be prudent in their strategic decisions especially related to capital structure and it also makes creditors lend prudently. It makes equity investments more secure by limiting risk and hence create a secondary market for equity instruments.

As can be observed from this literature review that efforts have been made in the past to delineate a mechanism for managing money supply (by limiting high powered money, using variable required reserve ratio, using full reserve ratio etc) instruments to be used in Islamic money market (Productive sector performance linked instruments for liquidity management), managing liquidity in financial sector (using two-way Mudarabah model, refinance ratio, Qard-e-Hasan ratio, composite stocks etc) and the role and functions of central bank. But much of that academic research has not translated into practice and least attention has been paid to the issue of establishing the benchmark for Islamic monetary system. This non-existence of a distinct and standardized benchmark has created obstacles in the creation and growth of more preferable Islamic alternatives like Mudarabah and Musharakah. This chapter tries to contribute in proposing a distinct, viable and stable alternative benchmark for Islamic finance industry which will be usable for pricing Islamic finance products in commercial banking (corporate and consumer both) and in pricing instruments for public finance, the trading in which will create a source of public debt financing and replacing conventional $\mathrm{OMO}$ by providing a base instrument in $\mathrm{OMO}$ in Islamic monetary framework.

\section{Central Banking Practices in Muslim Countries}

In UAE, the monetary instruments and liquidity management framework in the money market has following salient features: a) Minimum Reserve Requirement, b) Swap Arrangements, c) Advances and overdraft facility for banks and d) Certificates of Deposits. Source: Qualified Monetary Policy Instruments (Central Bank of UAE website, no date).

In Sudan, the monetary instruments and liquidity management framework in the money market has following salient features: a) Minimum Reserve Requirement, b) Central Bank of Sudan provides financial support to the Islamic banks facing temporary liquidity problems through purchasing financial papers "Sukuks" from them in accordance with what the Central bank may decide. Source: Central Bank of Sudan Policies for 2009 (Central Bank of Sudan website, 2009).

Chandavarkar (1996) citing the case of Saudi Arabia and Iran favored the use of reserve ratio and profit sharing ratio as the instruments of monetary policy management. He argued that adjustments in profit sharing ratios can be used as a substitute for bank rate variations. Credit can be tightened by reducing the share accruing to businessmen and eased by increasing it. 
The monetary policy of Saudi Monetary Agency (SAMA) relies primarily on variations in the reserve ratio requirements, since it is debarred from using the re-discount facility under Islamic law and cannot use open market operations as the Kingdom does not have any public debt in the form of government securities which can be used for such operations. A significant secondary tool is selective credit controls which include regulation of credit ceilings, cash margins, terms and conditions of customer transactions, limits, prohibitions on specific categories of loans, and fixing the assets to be held within the Kingdom by each bank. SAMA also deploys its own accounts and government deposits with commercial banks to regulate the money supply. SAMA uses ORR (Official Repo Rate) for short term liquidity management. Saudi Monetary system also has Government Development Bonds and Treasury Bills for fiscal deficit financing and liquidity management.

In Iran, the set of instruments used particularly since the abolition of banks specific credit ceilings at the beginning of 1991-92 comprises variations of reserve ratio requirements and the rates charged on lending of encashment facilities provided to banks. The reserve ratios are specified for each class of deposit, diminishing as their term increases (10 per cent on five years deposits to 30 per cent on demand deposits). Specialized banks are subject to a uniform (and lower) reserve ratio of 10 per cent. In Iran, RRR (Reserve Requirement Ratio), Participation Papers and ODA (Open Deposit Accounts) are used for short term liquidity management. Expected profit rates are determined by MCC (Money and Credit Council) in Iran.

In Qatar, the monetary instruments and liquidity management framework in the money market has following salient features: a) Required Reserve, b) Certificates of Deposit, c) QCB Rate, d) Repo Operation-Repo and e) Open Market Operations and f) Discount Window. Source: Monetary Policy Tools (Qatar Central Bank website, no date).

In Oman, the monetary instruments and liquidity management framework in the money market has following salient features: a) Treasury Bills, b) Certificates of Deposits, c) Open Market Operations and d) Repurchase/Reverse Repurchase. Source: Treasury Bill \& Certificate of Deposit (Central Bank of Oman website, no date).

Kazmi (2009) explained the Islamic money market framework in Pakistan. Two interbank trading agreements - the Interbank Musharakah and Interbank Wakalah - are being used as standard contracts for the Islamic banking industry. The Islamic interbank market is hoped to replace the conventional Karachi Interbank Offered Rate (KIBOR), with the Islamic Interbank Offer Rate (IIBOR), and offer an avenue for Islamic banks to lend excess funds to each other.

Interbank Musharakah is a short term restricted partnership where the banks are invited to invest the amount in a special pool of assets on a pre-agreed profit sharing ratio agreed upon at the outset. Interbank Wakalah is an investment management contract where the investor (entity with surplus funds) agrees to provide the Islamic bank (entity with shortage of funds) with funds to invest in 
different assets. The Islamic bank acts as the investor's agent and is paid a fee for its services, while the investor receives the returns obtained on investments.

In Malaysia, the Islamic Interbank Money Market (IIMM) was introduced on January 3, 1994 as a short-term intermediary to provide a ready source of shortterm investment outlets based on Shariah principle. Through the IIMM, the Islamic banks and banks participating in the Islamic Banking Scheme (IBS) would be able to match the funding requirements effectively and efficiently. Bank Negara Malaysia (BNM) issued the Guidelines on the IIMM on December 18, 1993 to facilitate proper implementation of the IIMM. Source: Islamic Interbank Money Market Malaysia Information (Islamic Interbank Money Market website, 2009).

Types of Instruments in Islamic Interbank Money Market

1. Mudarabah Interbank Investment (MII)

2. Wadiah Acceptance

3. Government Investment Issue (GII)

4. Bank Negara Monetary Notes-i (BNMN-i)

5. Sell and Buy Back Agreement (SBBA)

6. Cagamas Mudarabah Bonds (SMC)

7. When Issue (WI)

8. Islamic Accepted Bills (IAB)

9. Islamic Negotiable Instruments (INI)

10. Islamic Private Debt Securities

11. Ar Rahnu Agreement-I (RA-i)

12. Sukuk BNM ljarah (SBNMI)

13. Green Bankers Acceptances

14. Repurchase Agreements

15. Islamic Private Debt Securities

\section{Mudarabah Interbank Investment (MII)}

MII refers to a mechanism whereby a deficit Islamic banking institution (investee bank) can obtain investment from a surplus Islamic banking institution (investor bank) based on Mudarabah (profit sharing). The period of investment is from overnight to 12 months, while the rate of return is based on the rate of gross profit before distribution for investment of 1-year of the investee bank. The profit sharing ratio is negotiable among both parties. The investor bank at the time of negotiation would not know what the return would be, as the actual return will be crystallized towards the end of the investment period.

\section{Wadiah Acceptance}

Wadiah Acceptance is a transaction between BNM and the Islamic banking institutions. It refers to a mechanism whereby the Islamic banking institutions place their surplus funds with BNM based on the concept of Al- Wadiah. Under this concept, the acceptor of funds is viewed as the custodian for the funds and there is no obligation on the part of the custodian to pay any return on the account. However, if there is any dividend paid by the custodian, it is perceived 
as 'hibah' (gift). The Wadiah Acceptance facilitates BNM's liquidity management operation as it gives flexibility for BNM to declare dividend without having to invest the funds received.

\section{Government Investment Issue (GII)}

The Gll was introduced in July 1983 under the concept of Qard al- Hasan. The concept of Qard al- Hasan does not satisfy the Gll as tradable instruments in the secondary market. To address this shortfall, BNM opens a window to facilitate the players to sell and purchase the papers with the central bank. The price in trade between the players is determined by BNM, which maintains a system to record any movement in the GII.

\section{Bank Negara Monetary Notes-i (BNMN-i)}

BNMN-i is an Islamic security issued by Bank Negara Malaysia replacing the existing Bank Negara Negotiable Notes (BNNN) for purposes of managing liquidity in the Islamic financial market. The maturity of these issuances has also been lengthened from one year to three years. New issuances of BNMN-i may be issued either on a discounted or a coupon-bearing basis depending on investors' demand. Discount-based BNMN-i is traded using the same market convention as the existing BNNN and Malaysian Islamic Treasury Bills (MITB) while the profit-based BNMN-i has adopted the market convention of Government Investment Issues (GII).

\section{Sell and Buy Back Agreement (SBBA)}

Sell and Buy Back Agreement (SBBA) is an Islamic money market transaction entered by two parties in which an SBBA seller sells assets to an SBBA buyer at an agreed price, and subsequently, both parties enter into a separate agreement in which the buyer promises to sell back the said asset to the seller at an agreed price.

\section{Cagamas Mudarabah Bonds (SMC)}

Cagamas Mudarabah Bond was introduced on 1 March 1994 by Cagamas Berhad to finance the purchase of Islamic housing debts from financial institutions that provides Islamic house financing to the public. The SMC Mudarabah Bond is structured using the concept of Mudarabah where the bondholders and Cagamas share the profits according to the agreed profitsharing ratios.

\section{When Issue (WI)}

When Issue is a transaction of sale and purchase of debt securities before the securities is being issued. The National Shariah Advisory Council viewed that the WI transaction is allowed based on the permissibility to promise for sale and purchase transactions. 


\section{Islamic Accepted Bills (IAB)}

Islamic Accepted Bill also known as Interest-Free Accepted Bill (IAB) was introduced in 1991. The IAB is formulated on the Islamic principles of AlMurabaha (deferred lump-sum sale or cost-plus) and Bai ad-Dayn (debttrading).There are two types of financing under the IAB facility, namely:-

\section{i) Imports and local purchases}

The financing would be financed under al-Murabaha working capital financing mechanism. Under this concept, the commercial bank appoints the customer as the purchasing agent for the bank. The customer then purchases the required goods from the seller on behalf of the bank, which would then pay the seller and resell the goods to the customer at a price, inclusive of a profit margin. The customer is allowed a deferred payment term of up to 200 days. Upon maturity of al-Murabaha financing, the customer shall pay the bank the cost of goods plus profit margin.

The sale of goods by the bank to the customer on deferred payment term constitutes the creation of debt. This is securitized in the form of a bill of exchange drawn by the bank on and accepted by the customer for the full amount of the bank's selling price payable at maturity. If the bank decides to sell the IAB to a third party, then the concept of Bai al-dayn will apply whereby the bank will sell the IAB at the agreed price.

\section{ii) Exports and local sales}

The bills created shall be traded under the concept of Bai al-Dayn. An exporter who had been approved for IAB facility will prepare the export documentation as required under the sale contract or letter of credit. The export documents shall be sent to the importer's bank. The exporter shall draw on the commercial bank a new bill of exchange as a substitution bill and this will be the IAB. The bank shall purchase the IAB at a mutually agreed price using the concept of Bai al-Dayn and the proceeds will be credited to the exporter's account. Domestic sales will be treated in a similar manner.

\section{Islamic Negotiable Instruments (INI)}

The INI covers two instruments such as:-

\section{i) Islamic Negotiable Instruments of Deposit (INID)}

The applicable concept is Al-Mudarabah. It refers to a sum of money deposited with the Islamic banking institutions and repayable to the bearer on a specified future date at the nominal value of INID plus declared dividend. 
ii) Negotiable Islamic Debt Certificate (NIDC)

The transaction involves the sale of banking institution's assets to the customer at an agreed price on cash basis. Subsequently the assets are purchased back from the customer at principal value plus profit and to be settled at an agreed future date.

\section{Islamic Private Debt Securities}

Islamic Private Debt Securities (IPDS) has been introduced in Malaysia since 1990. At the moment, the IPDS which are outstanding in the market were issued based on the Shariah compliant concept of Bai Bithaman Ajil, Murabaha and al Mudarabah.

\section{Ar Rahnu Agreement-I (RA-i)}

Under RA-I, the lender provides a loan to the borrower based on the concept of Qard al- Hasan. The borrower pledges its securities as collateral for the loan granted. However, in the event where the borrower fails to repay the loan on maturity date, the lender has the right to sell the pledged securities and use the proceeds from the sale of the securities to settle the loan. If there is surplus money, the lender will return the balance to the borrower.

BNM uses RA-I as a liquidity management tool for its money market operations. Return from the RA-I is in the form of gift (hibah) and is determined based on the average interbank money market rates.

\section{Sukuk Bank Negara Malaysia ljarah (SBNMI)}

This Sukuk based on the Al-ljarah or 'sale and lease back' concept, a structure that is widely used in the Middle East. A special purpose vehicle, BNM Sukuk Berhad has been established to issue the Sukuk ljarah. The proceeds from the issuance are used to purchase Bank Negara Malaysia's assets. The assets are then eased to Bank Negara Malaysia for rental payment consideration, which is distributed to investors as a return on a semi-annual basis. Upon maturity of the Sukuk ljarah, which will coincide with the end of the lease tenure, BNM Sukuk Berhad then sells the assets back to Bank Negara Malaysia at a predetermined price.

\section{Green" Bankers Acceptance}

Banks may purchase BA issued by other banks (inclusive of conventional banks) provided that it is a "halal" BA. To be considered as "halal", the BA must be:-

a. An export or sales BA

b. Drawn to finance "halal" goods or commodity. 


\section{Repurchase Agreements}

Although the application of Repo in Islamic banking is not exactly the same as the conventional Repo, the conceptual framework is still the same. Thus Repo in conventional banking is an agreement under which a seller of securities undertakes to repurchase the securities from a buyer at an agreed price on a specified future date. However, in Islamic banking, the agreement to repurchase back the securities is just an agreement and not a condition for the contract to be settled. Thus this means that there are two contracts involved in Islamic Repo. The first one is to sell the securities and the second one is to purchase back the securities.

\section{Islamic Private Debt Securities}

IDS have been introduced using different types of Shariah concept namely through Bai Bithaman Ajil, al-Musharakah, al-Mudarabah, Qard ul Hassan, Murabaha etc. Under the concept of Bai' Bithaman Ajil, the financiers purchase an asset from the borrower and later resell the assets at a higher price which contain the cost and profit element. The loan which arises from the finance will be securitized through the issuance of two notes that is the primary notes which is equivalent to the asset price that is purchased by the financiers from the borrower and secondary notes which is equivalent to the profit value of the resale price. Both of these notes are traded in the secondary market under the concept of Bai' al Dayn.

Through Qard ul Hassan, the issuer of the notes is able to arrange the repayment of the loan which was given by the parent company. The IDS note is the evidence of debt for the amount which is yet to be repaid. Through the IDS, the loan is repaid by liquidating the IDS after certain period of time. The IDS is issued together with the Transferable Subscription Right (TSR). The TSR is the form of a "gift" (hibah) to the holder of the papers. The IDS is an alternative to the issuance of the conventional zero coupon bond.

Malaysia has the most sophisticated array of Islamic finance products. However, the prevalent use of Bai-al-Dayn (Sale of Debt) and Bai-Inaah (Buy Back) does not have the same support from Islamic scholars worldwide and hence it warrants us to look for better alternatives which are compliant with Islamic principles.

In the following lines, we propose a distinct, viable and stable alternative benchmark for public finance which will be usable for pricing government bonds, the trading in which will create a source of public debt financing and replacing conventional $\mathrm{OMO}$ by providing a base instrument in $\mathrm{OMO}$ in Islamic monetary framework.

\section{Alternative for Public Finance Other Than Zakat}

Looking beyond imposing more taxes, we have another alternative proposed by eminent scholar Muhammad Taqi Usmani. Usmani (2003) proposed issuance of 
GDP growth linked instruments to finance public debt. His proposal can be further polished by making a secondary market for it by directing banks to meet their statutory requirements through this instrument. This instrument will be a major investment alternative for money market players.

It will not be the same as bonds indexed for inflation. Bonds indexed for inflation are not recommendable as inflation does not always imply growth in production especially in stagflation. Moreover, inflation is more subjective and relative a measure to index an instrument with. Indexing the instrument based on Nominal GDP growth rate will be appropriate as the benchmark used will be related to production.

Therefore, it is plausible to use Nominal GDP growth rate as the benchmark for Islamic money market. Since this figure confirms the movement of both variables in the same directions, it can be used for indexing multilateral loans, loans between central banks and between central banks and international financial and development organizations such as IMF, WB, IDA, IDB, ADB etc.

It will not only compensate the financier for parting with liquidity and capital, but also provide a stable mechanism for recipient countries to get out of debt trap with debt servicing linked with output performance benchmark and it will provide relief in the balance of payment and foreign debt management to central banks in developing countries.

Figure 18: Nominal GDP and Real GDP for Pakistan 1999-2008

(Source: Social Indicators of Pakistan 2007)

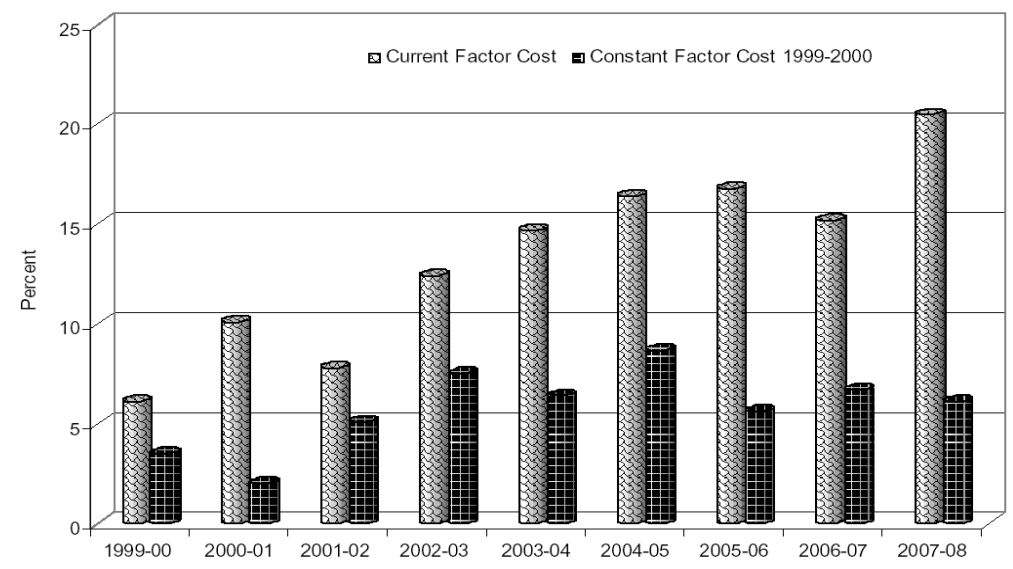

It can be seen from the figure below that Nominal GDP (GDP valued at current market prices) is greater than Real GDP (GDP valued at constant prices) in almost every year.

It can be argued that in recession, Real GDP may be negative, but NGDP growth rate will be positive. Will it not give an undue upward bias to the cost of capital when the production to which it is linked with is not increasing in recession? 
In recession, inflation is also low. In recession, if inflation is high, it is most likely a cost push phenomenon as in Pakistan. Stagflation or cost push inflation cannot be tackled with monetary policy alone and supply chain management is the answer to solve this problem.

Stagflation and cost push inflation can be better tackled with supply chain management, reducing middlemen ship, promoting competition. Scarcity of Capital created by interest can better be managed through a wealth tax as well i.e. Zakat in an Islamic economy. In Pakistan, when there is inflation and we are going through a recession (though not by the classic textbook definition of Real GDP being negative for 2 consecutive quarters), the discount rate is $12.5 \%$ for April-June 2010.

Inflation is most likely to be low in recession and hence NGDP growth rate won't be that high. Even if it is high, private sector financiers like banks would give financing based on Cash Flows discounted on that NGDP rate. Therefore, cost would have to be paid by the financees who have higher Cash Flows discounted on NGDP growth rate.

However, it needs to be appreciated that government would not be able to pass the buck on because recession means government having lesser tax revenue and will have to service at NGDP growth rate. But, government can take a wealth tax i.e. Zakat on wealth (stock rather than flow as income) to service it irrespective of the phase of business cycle.

In an Islamic economy, tax rate would be low (2.5\% on wealth, $5 \%$ and $10 \%$ on production), but tax exemption amount is also low. This will boost up production, improve competition and remove obstacles giving rise to cost push inflation and increase revenue for government by increasing the tax base.

It may be argued that by incorporating inflation in both public and corporate finance with a benchmark that takes into account inflation; then, government may not need to resort to printing paper money to meet the fiscal deficit if it can be met through other means. The chronic problem is to meet fiscal targets; deficit financing is resorted to if there is a failure in achieving fiscal targets. If necessary changes are made to avoid fiscal deficit as discussed in this chapter, paper money may not need to be printed often and signeorage will not feature as a potent problem. 


\section{Chapter 7}

\section{CURRENT ISLAMIC BANKING}




\section{Proposal for Islamic Economic Framework}

The most distinguishing feature of the Islamic economic system is the prohibition of interest. Usury, Interest and Riba are synonymous terms but they have different technical meanings. Usury refers to the consumption loans given on higher rates and thus causing exploitation of the borrower. Interest refers to the cost of using money in finance and economic theory.

Islamic economic principles have prominently been applied in financial industry especially in banking. In Egypt, first Islamic savings bank was established based on the principle of profit-sharing at Mitt Ghamr in 1963. The Islamic financial system in Malaysia was first introduced in 1963. It started from a modest beginning with the establishment of the Malaysian Pilgrims Fund Board (Tabung Haji), to the setting up of the country's first Islamic bank, Bank Islam Malaysia Berhad (BIMB), which commenced business on 1 July, 1983.

In 1975, the Islamic Development Bank was established to provide financing to projects in the member countries. Dubai Islamic Bank was the first modern Islamic commercial bank founded in 1975. Indonesia's first Islamic bank was Bank Muamalat, which was established in 1991. In Bahrain, first Islamic commercial bank was established in 1978.

In Pakistan, Meezan Bank was the first Islamic commercial bank established in 2002. Since then, Bank Islami, Dubai Islamic Bank, First Dawood Islamic Bank, Bank Al-Barakah and Emirates Global Islamic Bank have started their operations as fully fledged Islamic banks. The branch network of 6 full-fledged Islamic banks and 12 conventional banks (with dedicated Islamic banking branches-IBBs) increased to 528 branches by June 2009. It is estimated that Islamic banking will achieve a market share of 12 percent by 2012 in Pakistan. (Source: SBP Strategic Plan for Islamic Banking, 2009).

Total assets of Islamic banking in Pakistan reached Rs. 313 billion by June 2009. The financing and investment portfolio of Islamic banks reached Rs. 195.0 billion by June 2009. In terms of market share, total assets, financing \& investment and deposits reached 5.1 percent and 4.2 percent and 5.2 percent, respectively, at end June 2009. The deposit base of Islamic banks reached Rs. 238 billion at end-June 2009. (Source: Business Recorder, September 09, 2009). Lately, the Vatican said banks should look at the rules of Islamic finance to restore confidence amongst their clients at a time of global economic crisis. (Source: Osservatore, March 04, 2009).

Islamic Finance industry is a nascent but growing industry. Islamic financial industry beyond banking has achieved financial deepening in Mutual Funds industry, Investment Banking, Public Finance and insurance. On the geographical level too, Islamic banking has grown from Middle East to Europe and now is well positioned in South Asian markets as well.

In this chapter, a brief introduction about the currently practiced Islamic Banking is provided. 


\section{Assets: Financing, Advances \& Investments}

Assets are the financings and investments made by the bank for profit. Some of the important and often used financing products of Islamic banks are discussed below:

\section{Diminishing Musharakah}

In Diminishing Musharakah, the customer approaches the bank for joint purchase of an asset/property. Designated valuation agencies are consulted for the valuation of the asset/property. The seller of the property is paid by the bank and the bank and the customer enter into a Musharakah Agreement.

It is referred to as 'Diminishing Musharakah' because of the arrangement, the ownership stake of the tenant increases and that of the bank decreases or diminishes with the passage of time. The rent decreases as the ownership stake of tenant increases.

The share of the bank in asset/property is divided into units. These units are purchased by the customer periodically until he has purchased all units and becomes the sole owner of the asset/property. Rent is not charged immediately and is charged at the end of the month for the use of asset/property. Rent for at least one period is fixed. Unit price fixed for a period will not change during that period.

The rent is calculated based on 1 year $\mathrm{KIBOR}^{10}$. KIBOR is used as there is no other benchmark rate available. The logical argument is that in a society if there is only one merchant who sells prohibited products, and then he starts to sell one legitimate product, he can use the profit rates on prohibited products for pricing and calculating profit margin on the legitimate product.

In Musharakah Agreement, the floor rate (minimum rate) and the ceiling rate (maximum rate) is stated based on which the rent can vary. In Musharakah agreement, it is stated that if payment is made on time, the transfer of ownership will take place accordingly.

The risk of damage to the property is borne by the bank and the customer, according to the stake in the property at the time of disaster. Just like in conventional mortgage, a penalty is charged if a customer withdraws from the contract that is paid to charity. The logical argument presented for such a penalty is that the contract involves a promise/undertaking to pay rent and purchase units of the asset/property and if a customer withdraws from the promise/undertaking, he can be asked to pay a penalty for maintaining financial discipline.

${ }^{10}$ KIBOR (Karachi Interbank Offered Rate) is the rate at which banks provide funds to each other. 


\section{Proposal for Islamic Economic Framework}

Following table compares the conventional mortgage and 'Diminishing Musharakah'.

Table 11: Comparison of Diminishing Musharakah with Conventional Mortgage

\begin{tabular}{|l|l|l|}
\hline \multicolumn{1}{|c|}{ Features } & Conventional Mortgage & Diminishing Musharakah \\
\hline Benchmark Rate & KIBOR & KIBOR \\
\hline Basis of Inters / Rent & KIBOR & KIBOR \\
\hline Nature of Installment & Interest + Principal Repayment & Rent + Sale of Units \\
\hline Prepayment Penalty & Yes & Sale of Units at Higher Price \\
\hline Rent + Sale contract & Dependent & Separated by unilateral promise \\
\hline In subsequent years & Interest decreases & Rent payment decreases \\
\hline In subsequent years & Principal repayment increases & More Units are purchased \\
\hline Changes in Interest/Rent & Based on KIBOR & Based on KIBOR \\
\hline
\end{tabular}

\section{Murabaha}

Murabaha is a sale transaction. Technically, it is a deferred payment sale. If a trader has a right to sell a good at a profit, the bank should also have the right to sell an asset if he obtains physical/constructive possession of the asset and bears the risks related to the property until the sale is made to the customer.

Murabaha is used in working capital financing, SME financing and trade financing. The customer is asked to buy the asset acting as an agent to the bank because he has more knowledge about the product and better relationships with the supplier to obtain the goods at a competitive price and in a timely and appropriate manner.

In the case of import/export, if the exporter does not know the buyer of the asset (importer or bank), it does not matter. If $A$ takes a loan from the bank and buys an asset from $B, B$ has no concern from where the money is coming from (the buyer's own pocket or the bank). B's only concern is getting the price he is selling an asset for.

The Process flow of Murabaha is as follows:

Islamic bank and the client sign a Master Murabaha Finance Agreement and an agency agreement. The customer undertakes to purchase the asset from the bank. It is a one-sided promise and undertaking. According to the agency agreement, the customer purchases goods from the supplier on bank's behalf. The bank pays the supplier and obtains title and physical/constructive possession of the asset. The customer signs a declaration that he has purchased the goods on bank's behalf and now he is willing to purchase the asset. After offer and acceptance, sale is executed and the customer pays the agreed price to the bank. 
Rollover i.e. rescheduling in Murabaha is not allowed. The goods cannot be sold if they are consumed already. Penalty is charged if payment is delayed and is paid to charity.

\section{3. liarah}

ljarah means to give something on rent. In ljarah, right of use of a property is transferred to another person for a consideration. The lease period starts when the asset has been delivered by the lessee in a usable condition. The bank $\left(\right.$ Lessor $^{11}$ ) bears the ownership related costs and the customer (Lessee ${ }^{12}$ ) bears the usage related costs. Insurance, installation, import duty, delivery charges are paid by the bank and are added in its cost and recovered through transfer pricing. If the asset is destroyed or becomes unusable, the bank stops taking rent and does not charge rent for that period. Penalty for late payment is charged for maintaining financial discipline and is paid to charity. The asset/property remains in the ownership of the bank until the bank sells the asset to the customer in a separate agreement. The client is not obliged to buy the asset at the end of the lease period.

The process flow is as follows:

The customer approaches the bank for obtaining an asset on lease. The customer undertakes to make periodic lease payments for the lease period. Bank receives the title of the asset and pays the vendor. Lease agreement is signed whereby the bank leases the asset and the customer starts using the asset and pays rent for each period. In the end, the customer can purchase the asset from the bank by way of a separate purchase agreement.

\section{Salam}

It is used in financing goods and services that are not ready for spot sale and will have to be delivered later. In Salam, payment is in full at spot, but the delivery is deferred. It is used in special cases to facilitate transactions. In current practice, it is used in currency trade as an alternative for bill of exchange discounting and in agriculture financing.

\section{Istisna}

It is used in financing goods that are not yet ready for sale and will have to be manufactured. Example includes tailoring services, architect services etc. It is an order to producer to manufacture a specific commodity for the purchaser. It is used in pre-shipment exports financing and usable in all other situations where goods have to be manufactured before sale.

\footnotetext{
${ }^{11}$ Lessor is the owner of the asset.

${ }^{12}$ Lessee is the user of the asset.
} 
The bank asks the manufacturer to manufacture the goods. Upon delivery of the goods to the bank (physical/constructive), the bank appoints the manufacturer as its agent and orders him to sell the asset in the market to a potential buyer. The manufacturer sells the goods and pays the bank proceeds of the sale, net of agency fees in lieu of agency services rendered for the bank.

\section{Liabilities: Deposits}

Liabilities are the deposits placed with the bank. The two main categories of deposits are checking accounts and non-checking accounts. Some accounts are remunerative and some are non-remunerative. In the following lines, the deposit products offered by Islamic Banks are discussed below:

\section{Non-Remunerative Accounts}

Current Account is an example of a Non-remunerative checking account. The money deposited in such account is considered 'Qard' (Non-interest bearing loan). 'Qard' mode is used so that bank can utilize the funds deposited into the account and also be liable to pay to the customer upon demand. This way, the customer also has insurance of his principal amount. If 'Amanah' mode had been used, the bank would not have been able to use the funds deposited in the account and from the viewpoint of customer, the bank would not have been liable to pay the deposited amount in case it was lost not due to bank's negligence.

The money is invested in the fund by the bank. Bank utilizes the money to invest in ljarah, Murabaha, Diminishing Musharakah, Salam, Istisna etc. The money is payable on demand.

\section{Remunerative Accounts}

Remunerative accounts can be checking i.e. Savings Account or non-checking accounts i.e. Term Deposits. The money is invested in the fund. The bank acts as 'Mudarib' i.e. 'Fund Manager' and the customer acts as 'Rabb-ul-maal' i.e. 'investor'.

The money is only invested in Shariah compliant assets. Bank utilizes the money to invest in ljarah, Murabaha, Diminishing Musharakah, Salam, Istisna etc. The Weightage is assigned to each category of investment that is stated to the customer at the outset. Profit is declared at the start of the month for the previous month based on the weightage previously announced. Profit is paid out of the actual Gross Income. 
The profit is distributed as follows:

\begin{tabular}{|l|l|l|l|l|l|}
\hline \multicolumn{1}{|c|}{ Category } & Deposit (Rs.) & \multicolumn{1}{|c|}{ Weightage } & \multicolumn{1}{|c|}{$\begin{array}{c}\text { Weighted } \\
\text { Average }\end{array}$} & \multicolumn{1}{|c|}{ Profit } & \multicolumn{1}{|c|}{ Rate $^{\star}$} \\
\hline Savings & 3,000 & 0.1 & 300 & $57^{13}$ & $1.89 \%^{14}$ \\
\hline 1 Month & 1,000 & 0.3 & 300 & 57 & $5.66 \%$ \\
\hline 3 Months & 3,000 & 0.5 & 1,500 & 283 & $9.43 \%$ \\
\hline 6 Months & 6,000 & 0.6 & 3,600 & 679 & $11.32 \%$ \\
\hline 1 year & 7,000 & 0.7 & 4,900 & 924 & $13.21 \%$ \\
\hline Total & 20,000 & & 10,600 & 2,000 & \\
\hline
\end{tabular}

Profit $=\frac{\text { Wt.Avg.Investment }}{\text { TotalWt.Avg.Investment }} x$ TotalIncme

Profit Rate $=\frac{\text { Pr } \text { ofit }}{\text { Investment }} \times 100$

In last few years, Islamic finance industry experts have developed Shariah Compliant instruments for managing liquidity. Some of them are as follows:

a. Bai Salam in Bill Discounting.

b. Murabaha in Usance Bill Discounting.

c. Running Musharakah.

d. Musawamah for Short Term Liquidity Management.

e. Treasury Financing/Investments by way of Pool Management mechanism.

f. Treasury Investments/Financings by way of Short Term Investment through Commodity Murabaha i.e. Tawarruq.

g. Shariah Compliant Asset Backed Securitization like Sukuks.

h. Development of Islamic Benchmark i.e. IIBOR and Islamic T-Bill is underway which will deepen and integrate the financial markets comprising Islamic Financial Institutions.

Islamic Finance is catering to the needs of all investors. Islamic finance apart from being Shariah Compliant also has ample potential to attract investors solely from the business point of view as well. Islamic Finance is growing in multiple dimensions and is now spreading in other financial sectors like insurance,

$$
\begin{aligned}
& { }_{13} \frac{300 \times 2,000}{10,600} \\
& { }_{14} \frac{57}{3000} \times 100 \%
\end{aligned}
$$

(C) All Copyrights Reserved by Islamic Economics Project 


\section{Proposal for Islamic Economic Framework}

structured finance, project finance, mutual funds, syndicated finance, investment banking etc.

Islamic Finance is now able to provide one stop solution to its customers. Shariah compliance also ensures Corporate Social Responsibility (CSR) and ethical compliance. Islamic banks do not conduct business with companies producing tobacco, alcohol or engaged in business of gambling, casino, nightclubs, prostitution etc. This mechanism has given Islamic banking the name of 'ethical banking' in Europe.

Islamic Investments are not involved in Risk Arbitrage, Junk Bonds, Muni Bonds, Brady Bonds, Currency Options, Swaption, Swaps, Call/Put Options, Combinations or spreads of Options, Futures trading, Forward contracts, Credit Default Swaps, short selling, speculative insurance underwriting, subprime loans, debt swaps, rollover loans, CDOs, excessive leveraging etc.

The balance sheet of Islamic banks is capable of taking financial shocks. Islamic banks are not obliged to give fixed return to their depositors and general creditors. The creditors, shareholders and depositors share and participate in the bank's business. Therefore, incase, there is a shock on asset side (NPL increasing), Islamic banks will be able to share this loss with their depositors and shareholders.

Islamic banks cannot rollover loans. Therefore, the packaging and repackaging of loans and then issuing more and more debt securities on the back of these non performing loans cannot legally happen in Islamic Banks. Islamic banks are obliged to have backing of assets in all their investments. Therefore, Islamic banks losses even theoretically cannot go beyond the value of the real asset.

Next, we briefly look at some of the criticism that is made on Islamic banking. ElGamal (2008) criticized current Islamic banking by stating that the primary emphasis in Islamic finance is not on e $\square$ ciency and fair pricing. Rather, the emphasis is on contract mechanics and certification of Islamicity by "Shariah Supervisory Boards.

However, fair pricing is a relative term and as higher prices or rents are bad for buyers and tenants, too low prices or rents are bad for sellers and landlords. The supervision by religious scholars ensures not only compliance with Islamic principles, but also in avoiding other unethical practices like fraud, money laundering, deceit etc.

There have been some disagreements in the industry which are also a problem for the industry going forward. OIC Fiqh Academy ruled organized Tawarruq as impermissible in 2009. Bai Inaah is considered permissible in some parts of the world like in Malaysia, but, in some parts like in Pakistan, it is considered impermissible. Similarly, in recent times some Sukuks after issuance have been rendered impermissible causing uncertainty for the stakeholders and investors. But, positively, there is consensus among Islamic finance scholars in Pakistan about the use of Bai Inaah, Bai Al-Arboon, Sukuks etc and no controversy to date 
has cropped up in Pakistan regarding the particular use of instrument in Islamic Finance.

On the structural shortcomings in Islamic banking to avoid commercial risks, Warde criticized Islamic finance on its inability to avoid 'Islamic moral hazard'; he defined it as unscrupulous behavior on part of those engaged in Islamic finance. This behavior encouraged by certain features of Islamic finance including the assumption of righteous behavior on the part of employees and customers of Islamic banks the use of religion as a shield against scrutiny.

But, Imran Usmani (2009) in his article "Examining the Risk Prudence of Islamic Banks: A Risk Management Perspective" elaborated at length the risk mitigant tools used by Islamic banks for risk management and the financial crisis of 200709 did not affect Islamic banks as much as conventional banks.

In the next chapter, preferable alternatives in areas where shortcoming is observed and need for improvement is felt in practiced Islamic finance with respect to their socio-economic effects are suggested (See Appendix 2 for background reading on this issue).

Nevertheless, I have high regards for the commitment and sheer dedication with which Islamic banking was introduced in Pakistan. In my proposal too, instead of reinventing the wheel, I have suggested things in which there is already a common academic understanding, though they may not seem easy for private enterprises to implement on their own. Hence, the efforts done by proponents of Islamic banking on private scale are highly commendable and must be supported to further the goal towards equitable distribution of income. I have no doubts in my mind that the scholars who put forward the concept of Islamic banking had and have not done it for material benefit, rather they undertook it as a cause and they are committed to it indeed. Thus, if they have been and are committed in this endeavor, they will be rewarded in life hereafter, I sincerely pray. 


\section{Chapter 8}

\section{Proposal for Financial FRAMEWORK}


In the following lines, holistic set of changes are recommended in the financial system as part of the proposed economic framework.

Riba technically means "Any excess benefit derived on a loan over and above the principal". Therefore, definition of Riba encompasses interest and usury taken on consumption or commercial loans as well. However, there have been debates on whether the present day competitively set interest rate within a competitive financial industry comes under the interest that was prohibited 14 centuries ago. But, this issue has been settled now that interest in all its forms and manifestations must not be allowed (Usmani, 2007).

Muslim economists have given some alternative approaches for the development of an interest free financial system besides the criticism on interest.

Khan (2004) argued against elimination of interest by a legal decree and favored free market forces to bring the interest rates down to zero. He also emphasized on providing incentives for the use of equity over debt financing. He proposed following policy measures:

1. Reducing reserve requirements to increase supply of lent funds.

2. Strengthening the system of social security and income maintenance to safeguard the interest of lenders whose major source of income is interest i.e. pensioners, widows, retirees, disabled, old etc.

3. Enforcing unlimited liability.

4. Gradual decline in interest to make investments in debt based instruments less lucrative and shift loanable funds towards equity based instruments.

5. Allowing dividend as a tax deductible expense.

6. Providing fiscal incentives to non-leverage firms and disincentives to leverage firms.

These recommendations worth serious consideration, but, reducing reserve requirement could bring inflation especially if only market forces are given a mandate for elimination of interest without a legal decree. Furthermore, limited liability is only available in partnerships which as are not as common and popular forms of business organization and in corporations. Limited liability in corporation serves the interest of shareholders which among others are individuals from general public. Limited liability solves the agency problem by acting as a check on managers to be prudent in their strategic decisions especially related to capital structure and it also makes creditors lend prudently. It makes equity investments more secure by limiting risk and hence create a secondary market for equity instruments. 


\section{Proposal for Islamic Economic Framework}

Smolarski et al. (2006) analyzed options from Islamic point of view and argued that Options may be permitted for hedging purposes in Islamic finance as long as the underlying economic activities are themselves permissible from an Islamic point of view.

Mehmood (1990) introduced the TMCL model which is based on the basic idea that in a loan arrangement, both the amount of loan and time to maturity are equally important. Thus, if the amount of any loan is multiplied by the period for which it is extended, the result would be a unit i.e. loan value (LV). Thus an amount of Rs. 1000 for 1 year, has the same loan value as Rs.125 for 8 years i.e. both sum up to the same loan value of Rs.1,000. Therefore, any combination of giving bilateral loans whereby the loan value remains same is in conformity with Islamic principles as it will fall in the realm of Qard-e-Hasan. Therefore, if a borrower needs a loan of Rs.1,000 for 1 year, he can give away a loan of Rs.125 for 8 years and get a loan of Rs.1,000 for 1 year.

Zaheer (1996) criticized TMCL concept arguing that TMCL is based on the premise that money ought to have time value, the Islamic prohibition of Riba requires that money should not be allowed to have any time value at all. Consequently, the TMCL proposal is contributing to resurrect exactly the same evil which Quran wants to see condemned to extinction.

Zaheer (2007) in his another work argued that Islam has emphasized that in case of transactions involving credit, whether in the case of sale or financial debt, it is highly important that the returned article be absolutely identical to the one borrowed; otherwise there is a danger of interest being involved in the exchange. This principle can be applied to index financial loans in the inflationary or deflationary periods when the value of the amount returned undergoes either depreciation or appreciation compared to what it was when borrowed. He further stated that giving interest to a lender in a period of high inflation at a rate less than the inflation rate, which is called negative rate of interest, is also unfair for the lender and, therefore, should be avoided. In other words, the prohibition of Riba applies to real interest, not nominal interest, as with inflation a ban on the latter may result in negative real interest.

This recommendation is a deviation from conventional thought, but following arguments can be raised against it. Real interest rates in most developing countries are and have been negative. Following the true spirit of Quran and Hadith, we would be better off devising an alternative system in which we do not have to continually make a compromise between interest and inflation, growth in aggregate demand and inflation and money supply and interest rates.

Furthermore, real interest rates net of inflation are still not real ideally. Opportunity cost of forgoing use of money at a given point in time will include many other things and different for different individuals. Even the best alternative forgone is not quite known in many given situations and it would be different for different individuals having different circumstances. Best alternative forgone cannot even be restricted to a financial paradigm. If a catastrophe damages the asset for which money was borrowed, both parties or at least one of them will 
lose no matter what they decide as a matter of resolving the issue. Furthermore, the very basis of our existence is that we have been sent here for a trial. Absolute justice cannot be provided in this world for natural, financial, physical, knowledge, social and legal constraints.

As discussed in later chapters, time value of money is the problem of the lender. It is not the problem of the borrower. Lender cannot demand any compensation or the opportunity cost. The borrower cannot be obliged to pay the opportunity cost other than the principal amount. Interest rates in a given country are a function of many things other than just domestic inflation. Cost-push inflation is driven by supply shocks. Therefore, deterioration in real purchasing power is caused by factors not in the control of the borrower. He cannot be held liable to compensate in a matter in which he was not responsible. Furthermore, inflation is measured by an index which has an urban bias, period bias and representative bias inherently. If indexation is permitted, we will have to index compensation to other factors of production e.g. wages, rent etc.

Siddiqui (2005) highlighted that as per Islam, what is unacceptable is trading money paid now for money paid in future with an increment. A direct deal between producers and consumers/users of goods or assets rarely takes place... There are intermediaries between producers and users/consumers. Traders in fact never intend to use the goods they buy. Their purpose is making a profit by selling what they purchased, often to its user/consumer.

In some cases this intermediary is a financial intermediary. An Islamic financial intermediary enters into Islamic contracts to make profits by providing finance to those who need it. It does not lend money but pay for the needed goods or assets to its supplier and handing over the asset or good to the user/consumer.

Toutounchian (2006) also differentiated between money and capital and reasoned that if capital is combined with labor, it produces profit, but if money alone is lent, the interest it earns is not permissible.
$M:\{(1) L=100 \%$;
(2) $\mathrm{V}>1$;
(3) $\mathrm{MC}=0$;
(4) $d=0$;
(5) ó=0;
(6) $R=r\}$
$K:\{(1) L<100 \%$;
(2) $\mathrm{V}=1$;
(3) $\mathrm{MC}>0$;
(4) $d>0$;
(5) ó>0;
(6) $R=\tilde{n}\}$

Where: $\mathrm{L}=$ liquidity; $\mathrm{V}=$ velocity $\mathrm{MC}=$ marginal cost; $\mathrm{d}=$ depreciation

$R=$ return; ó = risk; $r=$ rate of interest; and $\tilde{n}=$ rate of profit

In proposing the appropriate method of pricing capital, Mannan (1982) proposed the use of accounting price of capital which will neither add to the cost of production nor form part of the profits; but, instead will be used to appraise projects. 


\section{Application of Time Value of Money}

Time value of money is the basis of interest. Interest is said to be the charge on the use of money for a particular time period. Islam prohibits interest that entails that no incremental amount can be charged for the use of money for a particular time period.

In investment for trade (which Islam allows), the investment will have to go through the entire process of a commercial activity that involves risk taking at each stage and any compensation on investment will be strictly dependent upon the outcome of the commercial activity. Time value of money is the problem for the investor to avoid keeping his money idle and to avoid forgoing the use of money that may bring positive value to his investment. However, it does not mean that the investor can demand an arbitrary increase (or is given as the case may be) as the cost of using money without taking the market and price risk.

A trader facing the problem of time value of money will invest his money in a commercial activity, bear all the risks especially the market risk and price risk and will eventually make a profit or loss. The profit for the businessman strictly depends upon the actual profit realized after taking market risk including price risk. It does not depend upon time.

\section{Pricing Capital in an Interest Free Economy}

\section{Pricing of Capital in Public Finance}

Data for the period 1970-2008 for a group of big economies i.e. America, Britain, Canada, China, the euro area, India and Japan is shown on the variables Nominal Interest Rates ( $t$ ) and Nominal GDP Growth Rate ( $\mathrm{t}-1)$ since Nominal GDP responds to interest rate changes as it decreases aggregate demand for the subsequent period, a lag variable for GDP i.e. GDP (t-1) is taken.

Both variables virtually moved together throughout the period and especially since 1990. Since this figure confirms the movement of both variables in the same directions, it can be used for indexing loans from the rest of the world and initially by Islamic Development Bank for its financing assets.

IMF provides lending to member countries for dealing with balance of payments crisis and maintain stability in the economy in the form of Stand-By Arrangements (SBA), Flexible Credit Line (FCL), Emergency Assistance (EA), Exogenous Shocks Facility (ESF) and Poverty Reduction and Growth Facility (PRGF) etc. If these loans are pegged with IMF's reserve currency i.e. SDR which is composed of a basket of currencies namely USD, JPY, GBP and Euro or pegged with USD or with any other hard currency, the financing facility so provided can be benchmarked using nominal GDP growth rate of the lender's country of origin or benchmarked with weighted Nominal GDP growth rate in major donor countries. 
Financing in development projects from World Bank and International Development Association (IDA) can also be benchmarked with weighted Nominal GDP growth rate in major donor countries or countries whose currency is included in the basket of currencies which make up SDR. This will be an alternative for market based financing. For soft loans, aid and grants, the Nominal GDP growth rate in the recipient country can be used. It will not only compensate the financier for parting with liquidity and capital, but also provide a stable mechanism for recipient countries to get out of debt trap with debt servicing linked with output performance benchmark. Having this relief in the balance of payment and foreign debt, countries will be well set to introduce the proposed benchmark for pricing treasury bonds. Financing from domestic commercial banks can be benchmarked with the national nominal GDP growth rate.

\section{Pricing of Capital in Corporate Finance}

In corporate finance, NGDP growth rate will be used in following valuation models:

1. It will replace $\mathrm{R}_{\mathrm{F}}$ in CAPM model.

2. It will help in calculating $\mathrm{Ks}$ and Capitalization rate in dividend discount model.

3. Income Bonds will be valued using DCF approach. The proposed benchmark rate i.e. NGDP growth rate would be used as the discount rate.

4. FCF could be calculated using this benchmark rate.

5. In project valuation, this benchmark rate would be used to find PV of Cash Flows. This would be appropriate due to following:

i. It will not lead us into falling in time value of money as we are using an enterprise or output related benchmark rather than interest based benchmark.

ii. The Cash Flows are obtained using equity contractual modes like Mudarabah and Musharakah.

iii. We are calculating valuation models for the investor and not for the borrower. Borrower or financee will be in no obligation to provide the returns based on these valuations. But, the investor can use this "indicative valuation" to rank investment alternatives.

iv. In actual distribution of income between financier and financee, profit sharing ratio would be used and applied to the gross profit earned by the financee. 


\section{Proposal for Islamic Economic Framework}

\section{Alternatives for Financing}

Earlier, we provided an alternative mechanism for public finance by issuance of a Nominal GDP linked instrument. But, there is a problem with pricing of capital this way in commercial banking. As per Islamic teachings, Capital is to be priced in an activity in which it participates and earns an actual reward. If one allows replication of this pricing methodology for public finance to seep into commercial financing, then, if an Islamic bank sells cotton, wheat, textile machinery, car or house, it will earn the rate of return on nominal GDP growth rate which has no causal relationship with cotton market, wheat market, textile machinery market, car and house market.

The real issue can not even be solved if one takes into account growth in particular sector. It is, because that is like giving an opportunity cost to capital and akin to interest. Variability is not the issue, linked to production is also not the issue. The real issue is that capital can only get profit on entrepreneurship in which it participates.

Preferably, house and car market should have a separate index, and pricing should be based upon that index. There is no big issue in house and car financing as they have secondary value. But, industrial machinery does not have a secondary value. Bank cannot take market/price risk in that regard. It has to lock the sale with combining two contracts. Islamic Banks do it with a unilateral promise which is binding legally, but not islamically as per them. In my humble opinion, it is like binding two contracts, confirming the 2nd leg with customer that it will buy machinery and only then we will execute the 1st leg i.e. bank will purchase if customer agrees to buy (and for that it will promise which is legally binding).

The solution to this is as follows:

The bank can give the capital without owning asset, no need for asset at all. Asset is needed if one wants rent or profit out of an asset. But in the proposed model, the bank will participate in business and not with the mentality that it wants rent on asset or profit on sale of asset irrespective of what the business does as in current Islamic Banking. It should be clear now why Islamic Banks rests on asset backing because they want rent on assets and not profit on entrepreneurial participation in business.

In the proposed model, the bank will give money, invest in the business (no asset involved) of the financee and shares profit at the gross profit level. No business exists or should exist if it is operating below shutdown point. There should not be many based upon economic theory. If almost all blue chip companies have positive net income, and surely, all will have positive gross income, they can be profitable and so can bank if it participates in their business. It can participate with blue chip companies as equity partner and with growth companies as creditor by issuing Income bonds i.e. participating in profit only and that too at gross profit level. 
Debt financing is a double-edge sword. Leveraged companies can magnify their returns in booms, but in slumps, they lose the edge and can even go bankrupt and make both their shareholders and creditors suffer. Debt financing results in a zero-sum game in which at least one stakeholder i.e. shareholders or creditors suffer. Equity financing ensures normal returns in booms and survival in slumps. Therefore, the company will not be squeezed of liquidity as interest expense as an 'autonomous expense' will not feature as a significant portion of total operating expenses.

A simplified economic model will highlight the point that equity financing is less risky and better prone to give profitable results in boom and in recession. In view of $\mathrm{EMH}$, profitability would be reflected in market prices.

\begin{tabular}{|l|l|l|l|}
\hline \multicolumn{4}{|c|}{ Non-Leverage Company } \\
\hline Assets & Rs. (in millions) & L + O.E & Rs. (in millions) \\
\hline F.A & 60 & Debt & 0 \\
\hline C.A & 40 & Equity & 100 \\
\hline Total Assets & 100 & Total L + O.E & 100 \\
\hline
\end{tabular}


Proposal for Islamic Economic Framework

\begin{tabular}{|c|c|c|c|}
\hline \multicolumn{2}{|c|}{$\begin{array}{c}\text { Case 1: Economic Boom } \\
\text { Income Statement (Non-Leverage } \\
\text { Company) }\end{array}$} & \multicolumn{2}{|c|}{$\begin{array}{c}\text { Case 2: Economic Recession } \\
\text { Income Statement (Non-Leverage } \\
\text { Company) }\end{array}$} \\
\hline & Rs in mln & & Rs in mln \\
\hline Net Sales & 100 & Net Sales & 60 \\
\hline CoGS (70\% of sales) & 70 & CoGS (70\% of sales) & 42 \\
\hline Gross Profit & 30 & Gross Profit & 18 \\
\hline Operating Expenses & 10 & Operating Expenses & 10 \\
\hline PBIT & 20 & PBIT & 8 \\
\hline Interest Expense (12\%) & 0 & Interest Expense (12\%) & 0 \\
\hline PBT & 20 & PBT & 8 \\
\hline Tax Expense (20\%) & 4 & Tax Expense (20\%) & 1.6 \\
\hline Net Income & 16 & Net Income & 6.4 \\
\hline $\mathrm{ROE}$ & $16 \%$ & ROE & $6.4 \%$ \\
\hline
\end{tabular}

A simplified economic model will highlight the point that debt financing can provide better profitability ratios in boom but it is more risky and less prone to give profitable results in recession. Keeping in view Efficient Market Hypothesis, profitability would be reflected in market prices.

\begin{tabular}{|l|l|l|l|}
\hline \multicolumn{4}{|c|}{ Leveraged Company } \\
\hline Assets & Rs. (in millions) & L + O.E & Rs. (in millions) \\
\hline F.A & 60 & Debt & 60 \\
\hline C.A & 40 & Equity & 40 \\
\hline Total Assets & 100 & Total L + O.E & 100 \\
& & & \\
\hline
\end{tabular}


Proposal for Islamic Economic Framework

\begin{tabular}{|c|c|c|c|}
\hline \multicolumn{2}{|c|}{$\begin{array}{c}\text { Case 1: Economic Boom } \\
\text { Income Statement (Leveraged } \\
\text { Company) }\end{array}$} & \multicolumn{2}{|c|}{$\begin{array}{l}\text { Case 2: Economic Recession } \\
\text { Income Statement (Leveraged } \\
\text { Company) }\end{array}$} \\
\hline & Rs in $\mathrm{mln}$ & & Rs in mln \\
\hline Net Sales & 100 & Net Sales & 60 \\
\hline CoGS (70\% of sales) & 70 & CoGS (70\% of sales) & 42 \\
\hline Gross Profit & 30 & Gross Profit & 18 \\
\hline Operating Expenses & 10 & Operating Expenses & 10 \\
\hline PBIT & 20 & PBIT & 8 \\
\hline Interest Expense (12\%) & 7.2 & Interest Expense (12\%) & 7.2 \\
\hline PBT & 12.8 & PBT & 0.8 \\
\hline Tax Expense (20\%) & 2.56 & Tax Expense (20\%) & 0.16 \\
\hline Net Income & 10.24 & Net Income & 0.64 \\
\hline ROE & $25.6 \%$ & ROE & $1.6 \%$ \\
\hline
\end{tabular}

The model shows that in economic booms, leveraged companies are more profitable than non-leveraged companies, but in recessions, leveraged companies are less profitable and hence riskier than non-leveraged companies. Hence, leveraged companies are depending on the assumption that the economic boom will last indefinitely.

Modigliani \& Miller (1963) argued that value of a levered firm is greater than the value of an unlevered firm. The difference in value comes from the tax benefit accruing to a levered firm. But, they ignored the bankruptcy costs and the case where even if a company is solvent, the economy may go through a recession.

Furthermore, if this tax benefit is provided to an unleveled firm by making dividends to be tax deductible; then, value of a levered firm may cease to have any extra value greater than an unlevered firm. 


\section{Proposal for Islamic Economic Framework}

\section{Limited Liability Partnership}

In this form of business, the liability of the partners is limited up to their investment in the firm as in the case of a limited company. Limited liability partnership does not contradict in any way with Islamic principles and hence will feature in proposed financial framework. In one Hadith, Allah has declared that "He will become a partner in a business between two partners until they indulge in cheating or breach of trust."

Venture Capital Funds in developed markets are established on limited liability partnership structure. Similarly, professionals also establish limited liability partnership. In VC funds, income bonds can be issued first before the company becomes profitable and then the stocks in the company can be acquired.

\section{2. ljarah with Options Contract}

The concept of Gharar (uncertainty) should not be used as shield to avoid price/market risk. 1400 years ago, the economy was agricultural and the agricultural yield was not predictable and homogenous. In Options contract, the obligation rests on one party and the other has an option. Therefore, it does not have any element of Gharar (uncertainty). Call premium is also charged to create financial discipline. If there is no call premium, then one will buy an unlimited number of options contract to hedge for each date for a same or similar price. Hence, options could be used in fixed asset/property financing to separate sale and tenancy contracts.

In the practiced Islamic banking, taking an undertaking from the financee is just like buying a put option from the financee who is acting as a put option writer. If this is reversed, the financee would buy the call option and the bank will sell the call option i.e. acts as call option writer.

The alternative is as follows:

The bank buys the asset/property paying the asset owner the full amount of the asset. The Bank is now the owner of the asset. It gives the asset/property on rent to the financee and at the same time, the bank enters into an option contract as the call option writer. In a European option contract (exercisable only at expiration date), the financee buys that call option which gives him the right to buy the asset at call expiration. He has the right but not the obligation to buy. The option writer however, is obliged to sell the asset if the call buyer decides to exercise the contract. For short term options contracts as in corporate financing, American style call options contracts (exercisable on or before expiration date) can also be used.

If the call buyer does not exercise, the option contract expires and the bank is in a position to give the asset/property on rent again. If the call buyer exercises the contract, the bank gets the asset price plus the rental income for the period before the expiration of the contract. 
The rent would be benchmarked using House Rent Index. This index could be established. The issue arises whether a fixed premium could be added or not. A fixed premium would ensure that even if the property for any reason reaches a value equal or close to zero, there is some rent charged greater than or equal to the fixed premium. However, since the contract itself does not have any connection with interest or interest rate benchmark and the rent is charged as long as the asset is in usable condition, it does not contradict with any of the Islamic principles. Here, one may point a contradictions that indexation on monetary loans is discouraged by Muslim scholars.

Responding to this argument, it must be emphasized that this contract is basically a tenancy contract and not a loan contract. Here, indexation is used, but it is a tenancy contract and not merely an extension of money loan. Indexation only in money loan is to be avoided.

In tenancy, rent accrues as long as contract remains in force and the asset remains in useful existence. In entrepreneurial ventures, profit accrues neither with time nor with any other factor. It results independent of time and its magnitude, positive or negative is not a function of a particular event or time. That is why; it must only be benchmarked with an index measuring profit alone in the underlying sectors/instruments without adding any fixed spread.

\section{Mudarabah}

A partner can opt for partnering only in profits. This arrangement of partnering only in profits is very different from interest based lending. An investor investing to earn interest gets the fixed amount irrespective of profit or loss of the borrowing entity. When a partner in a Mudarabah contract opts for partnering only in profits, he will only get a profit if the financee gets a profit. Therefore, this does not result in any exploitation of the financee and does not contradict with any of the Islamic laws. The modified Mudarabah will have the following characteristics. There will be two types of Mudarabah i.e. Mudarabah Corporate and Mudarabah Consumer.

\subsection{Mudarabah Corporate}

In practiced Islamic finance, the bank usually acts as a Mudarib. But, in the proposed framework, the Bank will act as a Rabb-ul-maal (investor) and will provide finance to business entities and corporations. This way, the fund will be utilized in productive uses rather than in the financial instruments.

In this contract, the bank acting as Rabb-ul-maal can opt to share only in the profits. This way the bank will be minimizing the risks and will get the principal paid back in full if the business incurs a loss. The validity of this arrangement has been discussed earlier. The Mudarib (Business enterprise) will not be willing to show losses because it will deteriorate its credit ratings and make it difficult for it to obtain finance through Mudarabah corporate in future. 


\subsection{Mudarabah Consumer}

In this contract, the bank will act as a Mudarib (Fund Manager). The investors acting as Rabb-ul-maal will provide investment which is put together in a fund. The bank (Fund manager) will invest the funds in the equity market, Mudarabah Corporate, ljarah and permissible derivatives like Options on ljarah (as discussed above) and Sukuks based on Asset Backed Securitization etc. The fund can declare the dividends either stock or cash as the case may be. The fund can be a closed end fund or an open-end fund.

The calculation of profits for each investor will also be simple as it will be based on the capital gains on investment as a difference between redemption and purchase prices calculated each day on the basis of NAV. Therefore, the bank will also avoid the complex profit calculation based on profit on daily product basis as in the current system.

\section{Leasing}

Operating lease is in accordance with Islamic principles since no interest is involved in operating lease. Lessee bears the executory costs relating to the use of assets and Lessor bears the executory costs relating to the ownership of the assets. The rent should be market based and mutually agreed upon. The term of lease can be made equal to the useful life of the asset if both lessee and Lessor agree. Another alternative is to use ljarah with options contract as proposed earlier.

The bank can also give the capital without owning asset, no need for asset at all. Asset is needed if one wants rent or profit out of an asset. But in the proposed model, the bank will participate in business and not with the mentality that it wants rent on asset or profit on sale of asset irrespective of what the business does as in practiced Islamic Banking. Instead of relying on rent on assets, banks can participate in business and earn profits distributed at gross profit level.

\section{Short Term Credit}

In the proposed model, the bank will provide capital and invest in the business (no asset involved) of the financee and share profits at the gross profit level. No business should exist if it is operating below shutdown point. If almost all blue chip companies have positive net income, and surely, all will have positive gross income, they can be profitable and so can bank if it participates in their business. It can participate with blue chip companies as equity partner and with growth companies as creditor by issuing Income bonds i.e. participating in profit only and that too at gross profit level. 


\section{Proposal for Islamic Economic Framework}

\section{Trade Finance}

In trade finance, the credit involved is usually for the short term. Bank as a financial intermediary can altogether be avoided by incorporating time for payment in the price. If the buyer would pay after 6 months and not at spot, price agreed upon can be set high. This would not contradict with Islamic principles as the sale of asset is involved, delivery is made spot and only payment is deferred. Price once agreed will not change. Bank would get agency fee for services, but not interest on the short term credit as no credit gets involved with the bank.

\section{Alternatives for Insurance}

Insurance serves a very important social need (general and life insurance) and commercial need (commercial insurance). In conventional insurance, interest, gambling and Gharar makes it unacceptable under Islamic principles. The alternative is recommended as follows:

Mutual insurance does not contradict with any of the Islamic principles. Therefore, general insurance and life insurance needs for living persons can be catered with Mutual Insurance. Insurance companies invest in mutual funds, equity markets, bonds, real estate etc to increase the value of their funds collected by way of premiums. People can insure themselves on their own by investing in mutual funds and pension funds. The insurance needs of salaried individuals can easily be catered by the employers themselves by establishing the mutual insurance system on their own.

But, the real problem arises in commercial insurance. Here, it needs to be kept in mind that not all risks are insurable. In fact, the risks generally insured by the commercial enterprises i.e. accidents, fire, destruction etc are remote risks than the risks which are uninsurable i.e. loss of customer's confidence, increased competition, regulation, taxes and decreased sales etc.

Governments if they have the fiscal space as they will have in the proposed framework, they can bail out any commercial enterprise suffering from any real and genuine mishaps. 'Gharimeen' is a head of Zakah. The Zakah funds allocated for distribution in this head can be used to pay the debts and accidental losses of the commercial enterprises. Furthermore, the contractual relationships will predominantly be of equity nature than debt nature and hence losses will be mutually borne than creditors getting fixed stipulated interest at the cost of shareholders suffering.

\section{Alternatives for Investment}

In the following lines, holistic set of changes are recommended in the proposed framework. 


\section{Islamic Income Funds}

Islamic Income Fund will derive its income from investment in ljarah (with Options), Musharakah (limited liability partnership) and Mudarabah. Islamic Banks provide income to their depositors on the same principle. Islamic Income Fund will be more diversified as it will be able to invest more funds in Islamic Banks with low NPLs and better risk management procedures. It will invest some funds in equity markets to provide better returns than Islamic Banks.

\section{Islamic REITs}

Real Estate Investment Trust (REIT) will invest in property market and gain through purchase/sale of properties and rental income. REITs investing funds in properties and giving them on rent will get regular rental income and hence will be able to provide their unit holders' regular source of income.

\section{Investments in NGDP linked Treasury Bonds}

Corporate finance managers and treasuries of financial and non-financial institutions can invest in treasury bonds which are priced using Nominal GDP growth rate.

\section{Investments in Foreign Currency}

Corporate finance managers and treasuries of financial and non-financial institutions can trade in different currencies as both are considered different commodities. This would be used to hedge currency risk. However, forwards, futures, options, swaps in currencies cannot be used.

\section{Investments in Stocks}

Corporate finance managers and treasuries of financial and non-financial institutions can make equity investments in common stock of different companies diversifying risk and stabilizing portfolio returns.

\section{Investments in Venture Capital Funds}

Corporate finance managers and treasuries of financial and non-financial institutions can make equity investments in VC funds or providing seed/bridge financing as an angel investor if FCFE permits to diversify risk and income stream.

\section{Investments in Corporate Income Bonds}

Income only bonds could be issued. These bonds need to be serviced provided there is income. The service payments on these bonds will be tax deductible. Tax deductible feature would benefit issuer and the compulsory servicing of bond in

(C) All Copyrights Reserved by Islamic Economics Project 
case of income would benefit investors to invest in blue chip companies. Companies which are not in the ranks of blue chip companies would issue convertible income bonds. Since there is a one sided obligation, it will not be against any of the Islamic principles. Exemption of investment in income bonds would also ensure the availability and supply of loanable funds in income bonds market.

Dividends will be allowed to be tax deductible; thereby, benefiting the company to benefit from tax advantage and increase the frequency of dividend payments and make it a regular feature. This will further boost and compliment the availability of loanable funds.

\section{Strategic Investments}

Corporate finance managers and treasuries of financial and non-financial institutions can increase capacity to bring economies of scale and scope, increase market share by increasing size of firm, diversity product line and target market, become a conglomerate, acquire a strategic target and tap other long term opportunities if there is surplus FCF.

\section{Making Equity Markets Efficient}

The proposed alternatives require equity markets to be efficient. Equity markets are complex and intertwined with other markets in a financial framework. In this short paper, only a brief outline of reforms is presented before the readers.

Information processing must be transparent. The role of CDC, Stock Exchange and SECP is to ensure that there is no insider trading, market manipulation and that rules, regulations and procedures are designed with an objective to protect investors, ensure their participation and increase their confidence. Strict check on broker's activities and cancellation of membership if any broker is convicted of a manipulation or fraud.

Stock trading in futures markets should be abandoned. Secondary market trading does not influence the financial health of businesses directly and futures market of stocks is not a need of the listed companies nor is it of any use to investors in stocks. Moreover, repeatedly it has been proved stock market crashes were caused by speculation in futures trading. Daily monitoring and settlement of margin calls encourages short-term focus.

With closure of interest based Savings, Fixed/Term deposit accounts, more money will come in stock market either directly or through mutual funds. New memberships can be given to encourage competition, sound market practices and to bring brokerage commissions down. It will make stock as well as commodity markets run efficiently with decrease in transaction costs. 
Primary market activities will increase since companies will no longer be able to generate finance through debt. Therefore, increase in listed companies will expand the market and diversify trading opportunities for investors.

A Company must pay dividends regularly and it must not be left on the will of the company directors to decide on this matter. One reason why companies do not pay regular dividends is because of expansion plans in future. But, even then, companies can float fresh shares and pay dividends still to their clientele. It has been explained earlier how scarcity of capital problem would be tacked with abolition of interest complimented with wealth tax and other fiscal incentives.

An investor could be given the right to decide whether he/she wants to get the regular dividend (only if profit is earned) or not. A Company can offer special benefits to those who don't want dividend immediately like selling shares to them at a discount price in IPO and subsequent PO.

Capital gains tax could be introduced. It will discourage day trading and check unnecessary speculation. It will make investors take a long term view and hence decrease market volatility. If necessary, capital losses can be permitted to be adjustable from the capital gains, but not exceeding the capital gains. 


\section{Chapter 9}

\section{MICRO CREDIT IN AN ISLAMIC ECONOMY}




\section{Poverty Alleviation in Proposed Framework}

In Pakistan, more than 25\% people live below the poverty line. Approximately, more than half of the population of Pakistan still lives in rural areas where Microfinance is needed. Approximately $40 \%$ of the labor force is employed in Agriculture and this sector can be the main target market for Microfinance.

Pakistan is the 7th largest country in population and has huge supply of young labor aged between 15 and 40. Informal credit markets already exist and recovery rates are higher i.e. 95\% offering a great opportunity for sustainable growth. Density of population is high in Pakistan and therefore, transaction costs would be lower than in regions where density of population is low.

Agri-based economies of Africa and Asia have fared well with increase in agriculture prices worldwide. Agriculture sector has not witnessed recession in the economic crisis of 2007-08. Inelastic demand of agriculture goods can better mitigate inflation risk and profitability risk. Grameen Bank in Bangladesh initiated by Nobel Prize winner Muhammad Younis has been a resounding success.

A Microfinance institution targets poor and whose average loan size is less than $250 \%$ of GDP per Capita of a country. In the proposed economic framework, employment in urban areas will already increase. But, we cannot solely depend on it for two reasons. There will be poor people residing in both urban and rural areas without any basic education and training, but they have needs to be fulfilled. Secondly, urban areas will increasingly become congested places with excessive migration into urban areas and therefore, we need to suggest tailormade solutions for rural areas suited to the rural setting. Microfinance institutions usually provide interest based loans. Since interest is not allowed in Islam, we will have to suggest an alternative to serve the same need without resorting to interest.

It is a hard enough job to keep record and supervise/regulate lending business in a grossly undocumented area. It would be a very daunting task to supervise/regulate while providing equity based financing. Profit Participation Certificates or Qard-e-Hasan can be provided, but that will create problems of supervision and documentation besides increasing the risk and limiting business profit potential.

The need will be met through two separate institutions:

1. Several Micro VC funds will be established either privately owned or government owned that will invest in Micro enterprises. The idea is that it is difficult to document each and every person's business. Therefore, group based lending will be provided. The group will form itself as a Micro enterprise. A Micro enterprise will be able to obtain economies of scale, better bargains and tap market effectively. 
2. There will be individuals left who will not be able to form a group and hence a micro enterprise and will require standalone financing. They will be financed through Qard-e-Hasan for consumption or small hard to be repayable business loans or by issuing Profit Participation Certificate (PPC). Showing honest records would be incentivized and bad performance will cease doors for further financing and hence incentives honest showing of business performance.

The source of funds will be as follows:

1. Government (Zakat Receipts).

2. Donors both local and foreign.

3. General and limited partners in a VC.

4. Small savings of dwellers.

5. Reserves built-up in past

6. Commercial enterprises investing to get tax rebates and improve corporate image through below the line activities.

Now, the question arises where will the work come from? The work will come in following forms:

a) Corporations outsourcing some of their tasks and operations. Corporations will need an incentive to outsource work to the micro enterprises funded by the Micro VC fund. The incentive will come from i) lower wages in rural areas than urban areas ii) Obtaining production even without incurring huge capital expenditures, acquisition of fixed assets, factory etc and iii) operational efficiency as there will be no need to hire permanent labor for the whole year.

b) Domestic work projects in rural areas producing a particular need of a rural, urban or export market.

c) Herding livestock in one's ownership or rendering this service for others.

d) Sharecropping using tenant-landlord or Musharakah / Mudarabah model. A precursor to this initiative would be an extensive land reform. Group based lending would ensure that land size is not reduced to an economically inefficient size.

e) Development/Construction projects in rural areas, e.g. building roads, schools, colleges, healthcare centre, mosques, bridges, cold storage, warehouse, railway tracks, post office etc.

The regions where population density is lower, mobile banking would be introduced in those areas. With the increase in number of Micro enterprises and Self-Employed Persons (SEP), wages in rural areas would increase. But, since there would be a disincentive to migration, corporations outsourcing their work projects will still save money in labor cost.

The human resource involved in Micro VC fund will be given compensation based on profit sharing, so that moral hazard and agency problem is avoided.

(C) All Copyrights Reserved by Islamic Economics Project 
The group will constitute members who can bring social collateral i.e. hold good image in their locality. SEP opting for Qard-e-Hasan (provided only where PPC cannot be used) or Profit Participation Certificate (PPC) would be asked to bring peer guarantees as is the practice in contemporary interest based microfinance institutions. Repayment incentive will be provided e.g. enhancing future credit line and a child's tuition fee for 1 year reimbursed if loan is paid on time.

Poor villagers have limited capacity to enter in corruption. They can hardly migrate abroad but they may decide to migrate to urban areas. To confront this case, a special mention can be made on their I.D cards that they have benefited from such Poverty Alleviation Fund. Furthermore, they will be asked to bring NOC from such and such Poverty Alleviation Fund. They are hardly trained in diverse works than the ones in which they are provided with training. They will hardly have any work experience other than the work they will be trained to do under the auspices of the Poverty Alleviation Fund. Therefore, they will have to mention their training and/or work experience to get a job in urban areas and at that point, they will have to show their IDs. Urban employers might hire them paying below minimum wages, but they will be penalized if such a happening comes under the knowledge of labor inspection team which would make regular visit to urban work settings to identify such a happening and prevent it to at least not becoming a norm.

Poor Villagers are members of a family system which usually has a larger family size than urban areas and has close relations with other families in the villages. Unlike in urban areas, an adult man in a village is better known in his locality. Training shall be made compulsory to all loan candidates. Training would be provided before they are provided with any financing. 


\section{Proposal for Islamic Economic Framework}

\section{Appendix 1:}

\section{A. Khan's Comment on A. Azim Islahi \& M. Obaidullah: Zakah on Stocks}

The paper has taken the existing discussion on the subject a step further. However, to my mind, the entire discussion on the subject is somewhat misplaced. It has generated out of a segmented approach to the subject of Zakah law and Zakah accounting. A different approach would not even raise the questions that are being discussed in this paper and elsewhere in the literature. The whole problem emanates from the first assumption: treating investment in shares as stock in trade. See how this assumption may not be realistic or at least problematic. Suppose two persons have one million dollars each. Both of them buy shares of a company with that money. One intends to keep that investment over a long period and the other has bought these shares for the purpose of selling when the market is favorable. According to the paper under review, we cannot treat both of them alike.

For this purpose, we would need to know the intention of each one of them. In accounting matters, such a situation could be problematic and nothing can be calculated on the basis of invisible intentions. Instead, let us take another route to the problem. We treat all investment in shares as investment. We need not distinguish between investment in sole proprietorship, partnership, joint stock company, for services or for manufacturing, etc. An investment in business is investment, irrespective of the nature of the business.

All wealth can be divided into two types: (a) liquid cash not invested anywhere, kept in bank, locker or in personal wallet. This is unproductive and idle wealth. (b) The other is investment in an asset. The asset could be for personal use such as a house, a car or a machine, etc. It could be for gaining profit in whatever form. The Zakah accounting should follow consistent rules in all situations.

The Zakah on idle cash would be levied at $2.5 \%$ of the value. This is straightforward and requires no discussion. The investment of wealth in assets of personal use is exempt from Zakah by a consensus. The Zakah on business investment requires discussion, however. For the sake of consistency, we should take a lead from those cases in which there is a consensus. For example, in case of agricultural produce, there is no Zakah or Ushr on the capital value of land by a consensus. It is the produce of land that is subject to Zakah @ 5\% or 10\%, depending upon whether it is irrigated or fed by rainfall. Similarly, if a person has let out a house, there is no Zakah on capital value of the house. The Zakah is payable on income of the house @ $5 \%$ or $10 \%$. If you are operating a taxi, there is no Zakah on capital value of the car. The Zakah is payable on the rental income @ $5 \%$ or $10 \%$. The question arises: If there is no Zakah on capital invested in land, house or car, why should it be payable if the money is invested in shares of a company?

The anomaly becomes obvious if we imagine two persons each having one million dollars. One invests in a business (buys shares), the other buys a building for leasing and earning through rental income. If we tax the capital value of the shares and do not tax the capital value of the house, we are introducing an 
anomaly. Instead, if we tax the dividend income of the one and rental income of the other, we shall be consistent. In brief, we should not worry about the valuation and other related question of the share capital. The Zakah is payable on the income from business, and capital remains exempt so far it is invested. It would be subject to Zakah if it were lying idle for a year or more.

The question would arise: what if a person invests in shares for a short while and keeps on rotating his capital in buying and selling of shares and he never earns any dividend? The answer is: In that case, each time he buys or sells shares, he would be making some financial gain or loss. At the year-end, all these gains and losses would be net off and if there is a net gain, he pays Zakah @10\% on the net gain. The capital would remain exempt until it is included in the idle cash and remains sitting there for a year. 


\title{
Proposal for Islamic Economic Framework
}

\section{Appendix 2: Looking for New Steps in Islamic Finance}

\author{
By Maulana Taqi Usmani
}

Islamic banking industry has grown rapidly during the past three decades spreading its operations in many parts of the globe. Making its first debut in the small Savings Association of Mitt Ghamr (Egypt) in 1963, its strength has now reached over 250 financial institutions operating in more than 40 countries with assets valuing USD 750 billion, and an annual growth rate of 15 per cent. Almost all the giant conventional banks are in queue to establish their Islamic units to capture the new emerging market. This rapid growth of Islamic financial industry is, no doubt, encouraging for those who wished to relieve themselves from the prohibition of interest on the one hand and to remain a part of the modern market economy on the other. Now that a substantial period of more than three decades has passed on the experience of Islamic Banks and Financial Institutions, it is imperative to review what they have achieved so far and what they have missed.

It is, no doubt, a great achievement of these institutions that they relieved the Muslims from clear prohibition of Riba, and came up with some alternatives that might be adopted in financial market without indulging in interest. In an atmosphere entirely dominated by interest-based transactions, it was really a formidable task. I do not agree with those who criticize them on the basis of utopian idealism, and claim that they should have brought an immediate revolution in the entire pattern of the financial market and should, at the very outset, have achieved the basic objectives of a true Islamic economy. This idealism that accepts no breathing space between $0 \%$ and $100 \%$ always tends to support $0 \%$ and to maintain status quo in practical terms. Looking from practical aspect, it is always a wise policy to start something that can be done in a given situation, even though it is less preferable from an idealistic approach. It was in this background that some instruments of lesser risk like Murabaha, ljarah and diminishing Musharakah etc. were allowed by the Shariah scholars. It is also wrong to say that these instruments have an element of camouflaged interest. In fact, if implemented with all their necessary conditions that have always been stressed upon by the Shariah scholars, they are substantially different from an interest based financing. At the first place, all these instruments are based on real assets, and do not amount to trading in money and financial papers, which is the case in an interest-based financing. Secondly, unlike an interest-based transaction, the financier, in each one of these instruments, assumes the risk of real commodities, properties or equipments without which the transactions cannot be valid in Shariah. Thirdly, these modes can be used only to finance a commercial activity that is permissible according to Islamic rules and principles.

These basic distinguishing features are enough to draw a line of difference between the two techniques of financing. Therefore, the notion that they are another form of interest is not correct.

Having said this, one must not forget that these instruments are not modes of financing in their origin. They are in fact some forms of trade that have been modified to serve the purpose of financing at initial stage as secondary and transitory measures. Since they are modified versions of certain forms of trade, they are subject to strict conditions and cannot be used as alternatives for

(C) All Copyrights Reserved by Islamic Economics Project 
interest-based transactions in all respects. And since they are secondary and transitory measures, they cannot be taken as final goal of Islamic Finance on which Islamic Financial Institutions should sit content for all times to come. It is a matter of concern for a student of Islamic finance, like me, that both these points are increasingly neglected by the players in the field, and especially by the newcomers in the industry. One should always differentiate between the transactions based on the original philosophy of a particular system and the transactions resorted to in exceptional situations on the basis of need. The former ones represent the real concept of the system, while the latter ones do not. The original concept of Islamic financing is undoubtedly in favor of equity participation rather than creation of debts, because it is only equity participation that brings an equitable and balanced distribution of wealth in the society. Debt-ridden economy, on the other hand, tends to concentrate wealth in the hands of the rich, and creates a bubble economy which fuels inflation and brings many other social and economic evils.

That is why, Islam has discouraged creation of debts, which should be resorted to in exceptional situations only, and encouraged equity participation, which is the best way to a just and balanced distribution of the benefits of commercial activities. Out of innumerable instructions given by Islamic resources to that effect, I would like to quote only two examples. It is reported by Sayyidah 'Aisha [], the blessed wife of the Holy Prophet allugate that, during his prayer the Holy Prophet allugatce used to seek refuge from indebtedness.

On the other hand, the Holy Prophet has declared that 'Allah Almighty remains with trade- partners (to help and support them) unless one of them becomes dishonest to the other.' These two comments made by the Holy Prophet aluswe are more than sufficient to show Islamic attitude towards debts as opposed to the equity participation.

In the light of the above, Islamic financial institutions have much to do before they achieve the desired objectives of a true Islamic economy. Although the traderelated instruments like Murabaha, ljarah etc. used by them in their operations, are not loans in strict terms, yet they create debts on the basis of deferred sales or renting. As explained above, debt-based instruments are not preferred ones, but they were suggested to be used as modes of financing to start the wheel of interest-free financing, and to bring an instant relief from interest in an atmosphere that was not fully prepared for immediate switch over to an equitybased system. It was a sort of first aid provided to a patient before he may have access to full medical treatment. No one can deny the importance of measures taken as first aid, but who can claim that they are the final cure of the disease, or that no further treatment is needed after them? Pain-killers are necessary to give immediate relief, but they are not enough to cure the deep-rooted ailments. The idea was that after starting their operations on the basis of these instruments, they should gradually proceed towards the ideal forms of Islamic finance.

Failure to abide by this idea has caused many problems resulting in total neglect of equity-based financing. Despite the differences we have explained above 
between interest and these instruments, they have many similarities in the net result, especially because of the benchmark used for their pricing. This has prompted Islamic Financial Institutions to compete with their conventional counterparts in all respects, and restrict themselves to the debt-based products. In their zeal to compete conventional banks, they are trying to invent 'Shariah compliant' counterparts for each and every financial product available in conventional capitalist market, regardless of whether or not they are in consonance with the ethos of Islamic economy. Instead of gradual progress towards equity, the tendency is to make maximum compromises to accommodate debt- related products matching with practices of the conventional market. Even derivatives are being designed on the basis of 'Shariah compliant' methods. If some products had to be equity based, they too were equated in some way or the other with a fixed return debt. 'Sukuk' was the best way to proceed towards equity, but in order to restrict the return of Sukuk holders, a threshold based on Libor is applied after which the whole profit is given to a particular party in the name of incentive for good management. In many cases, it is not even mentioned that after the fixed rate the rest is incentive.

This situation needs serious consideration of the players in the field and of the Shariah scholars who oversee the new products for Islamic financial Institution. Many conferences and seminars are being held frequently to consider various aspects of Islamic finance. I think it is high time now to find out ways and means to make our products not only compliant with, but also founded on Shariah. Our research should now focus on how we can move from debt-based to equitybased instruments in their true spirit, so that they may demonstrate the beauty of Islamic finance based on its economic ethos. No doubt, there are still some hurdles in their implementation, but they are not insurmountable for an industry that is growing so fast, if serious importance is attached to this vital issue, which must be the next topic of our discussion in a workshop devoted for this purpose. May Allah guide us all. 


\section{Appendix 3: Critical Analysis of Islamic Banking from Economic Standpoint}

Nowadays, much of the criticism made on Islamic banking takes into view the system as it existed in the $1^{\text {st }}$ phase of Islamic banking in Pakistan which was introduced in 1980s. Indeed, there were many controversial issues in the $1^{\text {st }}$ phase of Islamic banking and that is why, this phase had limited backing of Islamic scholars. But, $2^{\text {nd }}$ phase of Islamic banking which started in Pakistan with the establishment of Meezan Bank in 2002 is grossly misunderstood and even ignored in critical analysis of Islamic Banking.

Keeping aside my reservations even in the 2 nd phase of Islamic banking as will be discussed in this chapter, I must say that many problems and issues in the $1^{\text {st }}$ phase were resolved in the $2^{\text {nd }}$ phase and that is the reason why, the $2^{\text {nd }}$ phase of Islamic Banking had greater backing and support of not only the Islamic scholars but also of general public.

First, I take up the issues in philosophical basis of Islamic finance. Imran (2002) describing Riba-Al-Fadl stated that in homogenous commodities, unequal quantity cannot be exchanged whether on spot or on credit. In heterogeneous commodities, unequal exchange on spot is allowed, but deferred payment is not allowed. Explaining the logic behind this principle, he argued that a spot transaction of homogenous commodities is allowed because such a transaction will be carried out at the market rate. But, the question arises why the same argument is not accepted when the goods are homogenous, but the quantity is different due to quality. Why the market is assumed to set the right cross rate between different commodities in spot sale, but not in unequal amounts of homogenous goods even in a spot sale.

It is only in this case that the conventional understanding on Riba-Al-Fadl based on interpretation of two Ahadith is problematic. In credit transaction, interest can creep in and it suffices a logical test. If the conventional view on Riba-Al-Fadl is accepted; then, there arises a serious contradiction between Ahadith on Riba Nasiyah and the two Ahadith on Riba-Al-Fadl. The Ahadith which do not support the conventional viewpoint on Riba Al-Fadl are quoted below:

1. From Usamah ibn Zayd (rta): The Prophet (swt) said: "There is no Riba except in Nasiyah [waiting]." (Bukhari, Kitab al-Buyu', also Muslim and Musnad Ahmad).

2. "There is no riba in hand-to-hand [spot] transactions." (Muslim, Kitab alMusaqat; also in Nasa'i).

Next, I present my economic analysis of the practiced Islamic Finance. I must clear at the outset that I am no authority to render a thing permissible or impermissible. My submissions here represent my own viewpoint or more appropriately questions put forward to learned scholars. 


\section{Proposal for Islamic Economic Framework}

\section{Application of Time Value of Money}

Time value of money is the basis of interest. Interest is said to be the charge on the use of money for a particular time period. Islam prohibits interest that entails that no fixed amount can be charged for the use of money for a particular time period.

In investment for trade (which Islam allows), the investment will have to go through the entire process of a commercial activity that involves risk taking at each stage and any compensation on investment will be strictly dependent upon the outcome of the commercial activity. Time value of money is the problem for the investor to avoid keeping his money idle and to avoid forgoing the use of money that may bring positive value to his investment. However, it does not mean that the investor can demand an arbitrary increase (or is given as the case may be) as the cost of using money without taking the market and price risk.

Assigning weightage to investment based on tenor of investment through which horizontal distribution of profit takes place in Islamic banking creates the same yield curve as in the case of term deposits of conventional banks. The situation where losses are incurred would have been very interesting, but the money is invested in contracts in which the chance of loss is remote. Also, the arrangement is such that the bank makes sure that it gets comparable returns taking KIBOR as the benchmark rate.

A trader facing the problem of time value of money will invest his money in a commercial activity, bear all the risks especially the market risk and price risk and will eventually make a profit or loss. The profit for the businessman strictly depends upon the actual profit realized after taking market risk including price risk. It does not depend upon time.

The use of weightages as a compensation for time value of money will be appropriate if the business earns same level of profits and no loss in each period. This happens in the case of Islamic Savings Account and Term Deposits because the pool of money collected in the fund is invested in contracts in which chance of loss is remote. Now a discussion on those instruments (assets of the bank) will inquire that how these instruments enable the bank to provide compensation based on tenor.

\section{Analysis of Diminishing Musharakah}

In 'Diminishing Musharakah', two contracts i.e. tenancy and sale are included as two separate components of a Diminishing Musharakah contract. Both these contracts are separated by way of a unilateral undertaking in place of the actual simultaneous sale/purchase of units of the asset/property. The rent is calculated and charged on the basis of KIBOR. The rent increases when the KIBOR increases.

Upon close inquiry, one can notice that undertaking or promise makes the contract conditional. This argument is further substantiated by the fact that if the 
client refuses to undertake or promise to buy the asset (in units), the bank will not make contract with him. Furthermore, the promise gives the legal cover to the bank and is acceptable in a court of law.

Following table compares the conventional mortgage and 'Diminishing Musharakah'.

\begin{tabular}{|l|l|l|}
\hline \multicolumn{1}{|c|}{ Features } & Conventional Mortgage & Diminishing Musharakah \\
\hline Benchmark Rate & KIBOR & KIBOR \\
\hline Basis of Rent & KIBOR & KIBOR \\
\hline Nature of Installment & Interest + Principal Repayment & Rent + Sale of Units \\
\hline Prepayment Penalty & Yes & Sale of Units at Higher Price \\
\hline Rent + Sale contract & Dependent & Separated by unilateral promise \\
\hline In subsequent years & Interest decreases & Rent payment decreases \\
\hline In subsequent years & Principal repayment increases & More Units are purchased \\
\hline Changes in Rent & Based on KIBOR & Based on KIBOR \\
\hline Price and Market Risk & No & No \\
\hline Price of Asset & Locked at initiation & Locked at Initiation \\
\hline Cost to the borrower & Same in both cases & Same in both cases \\
\hline Profit to the bank & Same in both cases & Same in both cases \\
\hline
\end{tabular}

It can be seen from the table above that there is hardly any difference between the two modes of financing with respect to the flow of funds. It is argued by advocates of Islamic Banking that there is difference in the process flow.

Another argument that Islamic Banking advocates put forward regarding 'Diminishing Musharaka' is that the bank bears risks related to the asset/property and is discussed separately.

\section{Analysis of Risk Taking by Bank}

There are several types of risks. The most relevant risk is the market risk including price risk i.e. the risk that the goods will not be sold or will be sold at lower prices that may or may not cover costs. This risk is only borne by the seller when the goods are 'held for trade'. In 'Murabaha' and 'Diminishing Musharakah', operational risk is not taken by the bank. Delivery risk is borne by the exporter/seller who will only get payment if he delivers the goods in order. Insurance, import duty, levies, and all other expenses are indirectly charged from the customer through transfer pricing.

The occurrence of risk taken against 'destruction of property' is remote and this risk is also insured and the insurance expense is added in the cost and covered from the customer through transfer pricing. Had the tenancy and sale contract were made separately, the bank would have had to bear the market risk which the bank avoids by taking a unilateral undertaking from the customer to lease or purchase an asset in ljara/Diminishing Musharakah and Murabaha respectively. 


\section{Proposal for Islamic Economic Framework}

\section{Analysis of Murabaha}

It is referred to as "cost + profit" transaction. Maulana Taqi Usmani (2003) accepts the fact that 'difference in price in a spot and credit sale (where time of payment is delayed) is allowable with the condition that price once agreed cannot be changed'.

For example, if a person needs a machine worth Rs.100,000. The bank appoints the person as an agent to buy it and before it pays the amount (Rs. 100,000) to the supplier, the bank makes sure that the customer signs an undertaking to buy the asset. This undertaking by the customer is later used to sell the asset to the person at a profit. The bank makes sure that it gets the required profit by locking the price at the outset and avoids taking any market related risk.

The payment schedule is presented to the customer initially and whose values reflect time value of money. There is no rollover in Murabaha which is a distinguishing feature in Islamic banking i.e. price once agreed cannot be changed irrespective of delay in payment of Murabaha price, but the problem of contingency of two contracts (separated by way of a unilateral undertaking/promise from the legal standpoint) remains. Furthermore, it does not change flow of funds and does not contribute towards the socio-economic objective of income and wealth redistribution.

Undertaking to purchase the asset once the asset is bought by the client as an agent of the bank makes the contract conditional. This undertaking is taken from the client before the bank releases funds. This argument is further substantiated by the fact that if the client refuses to undertake or promise to buy the asset, the bank will not make contract with him. Furthermore, the promise gives legal remedy to the bank and is acceptable in a court of law.

Respected scholar Maulana Mufti Taqi Usmani (2002, p.13) describing the less ideal nature of Murabaha with respect to contributing to the goals of socioeconomic redistribution in economy wrote:

"The instruments of leasing and Murabaha are sometimes criticized on the ground that their net result is often the same as the net result of an interestbased borrowing. This criticism is justified to some extent, and that is why the Shariah supervisory Boards are unanimous on the point that they are not ideal modes of financing and they should be used only in cases of need with full observation of the conditions prescribed by Shariah."

Commodity Murabaha used by the Islamic bank's treasury for asset liability management (basing their actions on the opinion of scholars that 'Murabaha is allowed, even if not ideal') took the allowance to the extreme whereby in Commodity Murabaha transactions, the subject matter is not genuinely required by both financial institutions (lender and borrower), but they each take ownership literally for some minutes and execute a complex sale resulting in a profit for one and fulfillment of liquidity requirement for the other. Similarly, use of sale and lease back transaction in house construction finance and in commercial finance 


\section{Proposal for Islamic Economic Framework}

is also transaction in which Islamic bank purchases the asset without any need from the same customer to whom the asset is leased subsequently. The lapse of at least one year period between sale and lease recommended by Shariah scholars is also not a sufficient justification as the Islamic bank takes undertaking from the client.

With the current psyche of the bank to take no risk, the examples of diminishing Musharakah with a taxi driver or with a producing concern as given in Islamic banking literature will never get materialized. Fortunately, in Murabaha, ljarah and Diminishing Musharakah financing, the bank can eliminate all relevant risk and that is why, it is most common. With Murabaha as an alternative, the blue chip companies will not opt for 'purposeful' and 'long term' Mudarabah and Musharakah contracts. In case, if a company is in financial distress, the bank will not prefer Mudarabah and Musharakah contract with that company even if that company wants it.

With Murabaha as an alternative, profitable companies will not opt for Mudarabah/Musharakah because they will not like to share profits and else would go for cheaper way of sourcing funds i.e. debt financing. Less profitable companies will want to go for Mudarabah/Musharakah, but bank as conservative financial institution will not take risk with these companies. The argument that Mudarabah/Musharakah financing is not possible due to lack of authentic documentation and trust level is also very weak. Islamic banks operating in developed markets (it is to be noted that the developed countries are the hub of Islamic banking) where such problems are not found have also not gone for Mudarabah/Musharakah financing. As a matter of fact, Islamic banks do not want to take market and price risk. Default, credit, political, exchange and other risks are also taken by conventional banks. If Mudarabah and Musharakah are deemed ideal alternatives by Islamic banking experts and scholars favoring it; then, they would have been better off entering into investment banking before they entered into commercial banking.

In LCs, when bank gives a guarantee, it makes sure that it gets more in service charges if the amount is larger on the premise that bank's administrative cost increases if the amount is larger. Contrary to that, in liability products, bank gives a premium on the premise that bank's administrative cost decreases if the amount is larger. Risk assessment and risk taking are different things. In LCs, greater amount wise service charges are applied because the bank is managing risk, not just assessing it.

To secure this risk, the service charges will be proportional to the amount that is to be guaranteed. The argument that administrative cost increases in risk assessment is not valid factually and it is also contradictory to the practice in liability products whereby a premium is given on large deposits to encourage larger deposits on the premise that administrative cost decreases when the bank manages the larger deposit per account. 


\section{Analysis of Salam}

Salam is an alternative for short selling. Its allowance is confirmed from an authentic Hadith. It is a sale in which payment (in full) is at spot but delivery is deferred. But, it is to be noted that the transaction approved by Prophet Muhammad (PBUH) did not involve a financial intermediary. Ideally, we have to eliminate the need of excessive financial intermediation and the alternative methods to that have been suggested in this short book and more research is required in this regard. In parallel Salam, the same problem of contingency in contracts persists.

\section{Analysis of Mudarabah}

Mudarabah is said to be an Islamic mode of financing. At the age of 25, Prophet Muhammad (PBUH) entered into a Mudarabah contract with Hazrat Khadija (May God be Pleased With Her). This is a period before revelation. So Mudarabah as a mode of financing was prevalent. Since Mudarabah financing did not contradict with the values of Islam, people even after the beginning of revelation were allowed to enter into Mudarabah financing.

Secondly, in the example of Prophet Muhammad (PBUH), He entered into the contract as Mudarib (Businessman, Fund Manager or Asset Manager). So, the flow of money is from a rich financial entity to a business entity in need of finance. In currently practiced Islamic banking, the flow of funds is from the small pool of investors to a large financial entity. That large financial entity cannot invest the funds in instruments other than the financial instruments. Therefore, it has no productive effect on the economy and no employment and selfemployment generation takes place. Mudarib is a person in need of finance, bank as a reservoir of money acting as Mudarib does not contribute towards the socio-economic objective of redistribution.

The existing Mudarabah contracts cannot and will not influence the 'flow of funds' and 'wealth distribution'. For effective wealth distribution, bank should act as Rabb-ul-maal and companies as Mudarib. This way the funds will go to productive sectors.

Thirdly, Muslim jurists have formulated certain rules regarding Mudarabah financing that are now considered as 'Islamic rules of Mudarabah financing.' However, it must be emphasized that anything that does not contradict with any of the Islamic laws is permissible. The work of Muslim jurists serves as important guidelines, but should be open for modification upon reflection if a better alternative could be suggested. For example, one of the major impediments in the use of Mudarabah on the asset side of a bank i.e. for financing is that only Rabb-ul-Maal is considered to bear all the financial losses. Therefore, if an Islamic bank enters into the Mudarabah contract as a Rabb-ul-Maal, only the Islamic bank would have to bear all the losses. 
This condition does not even seem necessary from the study of Quran and Way of Prophet (PBUH) and even contradicted in Musharakah wherein all partners share in losses with limited liability.

Fourthly, it is argued that profit and loss sharing is the only alternative of interest. Khan (1982) has argued that profit and loss sharing is not the only alternative of interest. He argues that an investor can opt to become a partner only in profits. This is a common practice in limited liability partnership of professionals like lawyers and doctors where the other partners do not make good of any loss if the loss was solely caused by the actions of a particular partner.

This arrangement of partnering only in profits is very different from interest based lending. An investor investing to earn interest gets the fixed amount irrespective of profit or loss earned or incurred by the borrowing entity. When a partner in a Mudarabah contract opts for partnering only in profits, he will only get a profit if the borrower gets a profit. Therefore, this does not result in any exploitation of the borrower and does not contradict with any of the Islamic laws.

Moreover, in the conventional Mudarabah arrangement, Mudarib (Fund manager) bears no loss while he has the complete authority in running the affairs of the business. The Rabb-ul-maal (investor) is not allowed to interfere in the affairs of the business. When a loss occurs, the Mudarib acts like an employee of the business and when the profit occurs, he shares in the profit as if he was the only reason behind the profits.

\section{Securitization, Great Recession \& Islamic Finance}

The proponents of Islamic finance argue that the demise of financial institutions in developed markets was due to excessive securitization and this crisis has exposed the weaknesses in the interest based financial system.

But, securitization in Islamic finance is also possible and is used frequently in recent times. The argument that Asset backed nature of financing would ensure effective risk management is also weak as CMOs, MBS, ABS etc were instruments with mortgage loans as their underlying assets. The problem was with excessive leveraging and lax regulation and not with securitization per se. Securitization in Islamic finance as in Sukuks also suffered a setback in Dubai Crisis in 2009/10. Asset backed financing also lacks the potential to provide need based loans for education, marriage, financing to pay short term debt, salaries, other accrued expenses to $3^{\text {rd }}$ parties etc.

\section{Concluding Remarks}

The proponents of Islamic banking repeatedly try to give some logical answers to support the case of Islamic banking. These logical arguments are analyzed briefly.

It is said that a McDonald burger in west and east may taste same, but one may be permissible i.e. halal and one may be prohibited i.e. Haram if it is prepared 


\section{Proposal for Islamic Economic Framework}

from the meat of the chicken which was not slaughtered in the prescribed manner. It is a very weak argument. The prohibited burger is not prohibited due to the taste. It is prohibited because the prescribed manner of slaughtering is not followed to obtain the meet for the burger. The reason of prohibition is not biological (taste), it is psychological i.e. God has permitted to take the life of an animal, but humans must remember that it is God who has permitted them to take the life of an animal for food and must utter words which signify this understanding.

It is said that pre-marital and post-marital sex may give same utility, but one is permissible and one is not. Here again, the reason for prohibition of pre-marital sex is not biological or obtaining utility, but it is social i.e. Islam treasures family system and wants to protect its sanctity at all cost. The very structure of the family system rests on limiting free sex and confining it only to marital relations else from a social point of view, humans would be no different than animals.

Interest is prohibited because it can create exploitation of either borrower or lender. Quran said 'Do not do wrong nor be wronged' [Al-Baqarah: 280]. This exploitation can only be avoided if equity financing is used; else compensation to either party would not be justified (Imran Usmani, 2009).

The current Islamic modes of financing are different to the extent that process flow of events is different. Nothing can be charged on consumables including money but rent can be charged on tangibles like property or any rentable asset. The technique is to use the money to buy an asset and then sell the asset at a profit or give the asset on rental basis to earn rental income. Contingency of two contracts and the lack of socio-economic effects are the main problems in the practiced Islamic Banking products (other than Musharakah and Mudarabah which are hardly practiced).

Proponents of current Islamic banking argue against the viewpoint that interest is prohibited solely because of its economic evils. Explaining the verse (AlBaqarah:275), they argue that the verse was revealed to clarify the difference between credit sale (of the type which is used today in Islamic banking) and Riba. There is a huge difference between interest based economic activity and trade. If there had been a little difference, Allah would have given the reason for its prohibition in place of the verse in which Allah has declared the advocate of interest as the one who has become mad by the touch of the evil (2:275). Rather than being derisive here, arguments against interest should have been given. But, it was not needed because the people understood what was interest and what was trade. Respected scholar Mufti Shafi Usmani and Mufti Taqi Usmani while explaining verse 275 of Al-Baqarah stated that if this and similar injunctions do not become clear to the human mind, it should become a reason for argument and disbelief. However, if one reads the verse 275 of Al-Baqarah, it seems that Allah is criticizing using the very argument that no sane person can equate trade with Riba. If one does, then, he is like someone who has become mad by the touch of the devil. Following is the translation of the verse under discussion.

"Those who benefit from interest shall be raised like those who have been driven to madness by the touch of the Devil; this is because they say: "Trade is like 


\section{Proposal for Islamic Economic Framework}

interest" while God has permitted trade and forbidden interest." [Al-Baqarah:275]

If argument of interest not prohibited due to any explicit, logical and rational reason is taken; then, we ought to believe that Allah has declared an activity to be like waging War with Allah and Prophet and 70 times more heinous than committing adultery with one's mother without making it clear why interest is prohibited! Alternatively, if the explanation of the proponents of Islamic banking for verse 275 of Al-Baqarah is taken, then, it seems very strange that if no apparent difference exists in the economic effects of the two transactions i.e. credit sale which resembles Riba and Riba itself, why would someone indulge in Riba if the same level of profit can be achieved through a credit sale which resembles Riba. Secondly, how strange it would be to assume that Allah would punish taker of Riba so severely, while from the economic standpoint, the one who undertakes a credit sale transaction which resembles Riba would have earned the same level of profit.

Country risk, political risk, currency risk, default risk, credit risk, interest rate risk etc are taken by conventional banks as well. The relevant risk is the price risk i.e. sale price may not cover costs and the market risk i.e. goods/services may remain unsold.

Quran has directed Muslims to avoid accumulation of wealth [AI-Shura:4]. The current Islamic Banking is not working towards that end. If an activity can not contribute towards an Islamic objective, it needs to at least avoid doing harm to that objective. Though, proponents of Islamic Banking have promised and shown commitment that in the long run, they are working towards the objective of making a system conducive to achieve equitable distribution of income. But, if in next decade or two, the practiced Islamic Banking fails to give a result different from conventional banking in a capitalist economy; then, the proponents of Islamic Banking will have little authority remaining to criticize Capitalism.

Finally, I will quote a passage from the seminal book on Islamic Finance by respected scholar Maulana Mufti Taqi Usmani (2002). Islamic finance scholars and practitioners must look at that passage from time to time and determine their progress towards achievement of socio-economic redistribution in an economy and to what extent they deserve to be not criticized in the same way as Maulana Taqi Usmani criticized conventional banks.

Respected scholar Maulana Mufti Taqi Usmani (2002, p.17) wrote:

In the modern economic system, it is the banks which advance depositors' money as loans to industrialists and traders. If industrialists having only ten million of their own, acquire 90 million from the banks and embark on a huge profitable project, it means that $90 \%$ of the project has been created by the money of the depositors while only $10 \%$ has been created by their own capital. If this huge project brings enormous profits, only a small proportion i.e. 14 or $15 \%$ will go to the depositors through the bank, while all the rest will be gained by the industrialists whose real contribution to the project is not more than $10 \%$. Even this small proportion of 14 or $15 \%$ is taken back by the industrialists, because this proportion is included by them in the cost of their production. The net result is 
that all the profit of the enterprise is earned by the persons whose own capital does not exceed $10 \%$ of the total investment, while the people owning $90 \%$ of the investment get no more than the fixed rate of interest which is often repaid by them through the increased prices of the products. On the contrary, if in an extreme situation, the industrialists go insolvent, their own loss is no more than $10 \%$, while the rest of $90 \%$ is totally borne by the bank, and in some cases, by the depositors. In this way, the rate of interest is the main cause for imbalances in the system of distribution, which has a constant tendency in favor of the rich and against the interests of the poor.

Nevertheless, I have high regards for the commitment and sheer dedication with which Islamic banking was introduced in Pakistan. In my proposal too, instead of reinventing the wheel, I have suggested things in which there is already a common academic understanding, though they may not seem easy for private enterprises to implement on their own. Hence, the efforts done by proponents of Islamic banking on private scale are highly commendable and must be supported to further the goal towards equitable distribution of income. I have no doubts in my mind that the scholars who put forward the concept of Islamic banking had and have not done it for material benefit, rather they undertook it as a cause and they are committed to it indeed. Thus, if they have been and are committed in this endeavor, they will be rewarded in life hereafter, I sincerely pray. 


\section{Proposal for Islamic Economic Framework}

\section{References}

Business Recorder, Karachi (September 09, 2009) Islamic Banking Industry Registers $12 \%$ Growth, Staff Reporter.

Central Bank of UAE (no date). Qualified Monetary Policy Instruments. Available at: http://www.centralbank.ae/tools.php (Accessed: October 10, 2009)

Central Bank of Sudan (2009). Central Bank of Sudan Policies for 2009. Available at: http://www.bankofsudan.org/ (Accessed: October 10, 2009)

Central Bank of Oman (no date). Treasury Bills \& Certificate of Deposits. Available at: http://www.cbo-oman.org/ (Accessed: October 10, 2009)

Chandavarkar, Anand (1996). "Central Banking in developing countries". New York: Macmillan Press Ltd.

Chapra, Umer (2007). The case against interest: Is it compelling?. Thunderbird International Business Review, Vol: 49, no: 161-186, Wiley Periodicals.

Chapra, Umer (1993). “Islam and Economic Development.” Islamabad. Islamic Research Institute.

Chapra, Umer M. (1983). "Monetary Policy in an Islamic Economy". Institute of Policy Studies. Islamabad, Pakistan.

Darrat, Ali, F. \& Bashir, M. Abdul-Hameed (2000). "Modeling Monetary Control in an Interest Free Economy". J.KAU: Islamic Economics, Vol. 12, pp. 3-19.

Dawn, Karachi (September 07, 2009). “20pc Less Charity This Ramadan”. Economics \& Business Review. Afshan Subohi. p1.

Dawn, Karachi (April 12, 2010). “The Irrelevance of Monetary Policy”. Economics \& Business Review. Dr. Javed Akber Ansari. p V1.

El-Gamal, Mahmoud A. Islamic Finance: Law, Economics \& Practice. Cambridge: United Kingdom.

Farooq, Mohammad Omar, The Challenge of Poverty and the Poverty of Islamic Economics (2008). Journal of Islamic Economics, Banking and Finance, Vol. 4, No. 2, pp. 35-58.

Federal Bureau of Statistics [2008] Yearly External Data 2009, Islamabad.

Fukuyama, Francis (1992). The End of History and the Last Man. London: Penguin.

Government of Pakistan [2009] Budget Report 2008-09, Islamabad. 


\section{Proposal for Islamic Economic Framework}

Haque, Nadeem-ul \& Mirakhor, Abbas (1998). "The Design of Instruments for Government Finance in an Islamic Economy". International Monetary Fund. IMF Working Paper, WP/98/54.

Hashmi, Tariq (2002). "Condition of Tamlik in the Payment of Zakah". Renaissance. Vol 12 , Issue 10 .

Heckly, Christopher (2004). "Wealth Tax in Europe: Why the Downturn?" in Michel Taly and Gérard Mestrallet, dir., "Estate Taxation: Ideas for Reform”, Institute Reports, Paris, Institut de l'entreprise, pp. 39-50.

Huntington, Samuel P. (1997). "The Clash of Civilization and the Remaking of World Order". New York: Touchstone, Rock Feller Centre.

Islahi, Amin A. (1985). “Tauzeehat”. Lahore: Islamic Publications.

Islamic Interbank Money Market (2009). Islamic Interbank Money Market Information. Available at: http://iimm.bnm.gov.my/ (Accessed: October 12, 2009)

Johnson, L. Craig [Ed] Man Y. Joyce [Ed] (2001). “Tax Increment Financing and Economic Development: Uses, Structures, and Impacts”. S U N Y Series in Public Administration. New York: State University of New York Press.

Kahf, Monzer (1987). "The Early Islamic Public Revenue System" (Lessons and Implications). Jeddah: IRTI.

Kant's Critique of Practical Reason and Other Works on the Theory of Ethics, trans. Thomas Kingsmill Abbott, B.D., Fellow and Tutor of Trinity College, Dublin, 4th revised ed. (London: Kongmans, Green and Co., 1889).

Kazmi, Shabbir H. (2009). "Wakalah and Musharakah for Pakistan's Interbank". Red Money Group.

Keynes, John M. (1936). Theory of Income, Employment, Interest \& Money. New York. Polygraphic Company of America.

Keynes, John M. (1932). Economic Future of our Grand Children. Essays in Persuasion New York: Harcourt Brace.

Khan, M. Akram (2005). Comments on A. Azim Islahi \& M. Obaidullah: Zakah on Stocks: Some Unsettled Issues. J.KAU: Islamic Econ., Vol. 18, No. 1, pp. 41-42.

Khan, Muhammad A. (1982). "Inflation and the Islamic Economy - A Closed Economy Model." International Centre for Research in Islamic Economics. Jeddah: Kind Abdul Aziz University Press.

Khan, Muhammad A. (2004). "Elimination of Interest: A Proposed Strategy". Renaissance. Vol 14, Issue 1. 


\section{Proposal for Islamic Economic Framework}

Krugman, Paul [September 02, 2009]. “How Did Economists Get It So Wrong?”. Op-Ed Page, NY Times.

Kuran, Timur. (2006). "Islam and Mammon: The Economic Predicaments of Islamism". Princeton University Press.

Kuran, Timur (2003). "Islamic Redistribution through Zakat: Historical Record and Modern Realities,“ in Bonner, M, Ener, M, and Singer A. (eds.). Poverty and Charity in Middle Eastern Contexts, SUNY Press, pp. 275-293; pp. 275-276.

Leonard, Arthur G. "Islam, it's Moral and Spiritual Values". London: Luzac.

Liam, Murphy \& Thomas Nagel. (2002). "The Myth of Ownership: Taxes and Justice". London: Oxford

Mannan, M. Abdul. (1986). "Islamic Economics: Theory \& Practice”. London: Hodder and Stoughton.

Mannan, Abdul M. (1982).” Interest Free Islamic Economy - A Comparative Policy Approach." International Centre for Research in Islamic Economics. Jeddah: Kind Abdul Aziz University Press.

Maududi, Sayyid Abul A'la (1984) Tafheem-ul-Quran [Meaning of Quran], $3^{\text {rd }}$ Ed. Vol4. Lahore: Idara-e-Tarjuman-ul-Quran.

Maududi, Sayyid Abul A'la (1970) Ma'ashiyat-e Islam [Economic System of Islam], Lahore: Islamic Publications.

Marcuse, Herbert (1964). One Dimensional Man. Boston: Beacon.

Modigliani, F. \& Miller, M. (1963). "Corporate income taxes and the cost of capital: a correction". American Economic Review 53 (3): 433-443.

Moore, Molly (2006). "Old Money, New Money Flee France and Its Wealth Tax". Washington Post Foreign Service. Sunday, July 16, 2006; Page A12

Muir, William (1912). “Life of Muhammad”. Edinburgh: John Grant.

Nadvi, S. Moeen-ud-din (1996). “Taareekh-e-Islam [History of Islam]”. Lahore: Maktaba-e-Rehmania.

Osservatore. Vatican. (March 04, 2009). "Islamic Banking May Help Overcome Crisis". Press Release.

Pal, Izzud-Din (2006). Islam and the Economy of Pakistan. Karachi: Oxford University Press. 


\section{Proposal for Islamic Economic Framework}

Peace Research Institute Yearbook [2009]. Stockholm International Peace Research Institute.

Powell, Russell, Zakat (2009): Drawing Insights for Legal Theory and Economic Policy from Islamic Jurisprudence (February 28, 2009). Available at SSRN: http://ssrn.com/abstract=1351024

Qardawi, Yousuf Al (2000). "Fiqh Al Zakah. A Comparative Study of Zakah, Regulations \& Philosophy in the Light of Quran \& Sunnah". Jeddah: Scientific Publishing Centre.

Qatar Central Bank (no date). Monetary Policy Tools. Available at: http://www.qcb.gov.qa/English/PolicyFrameWork/MonetaryPolicy/MonetaryPolicy Tools/Pages/MonetaryPolicyTools.aspx (Accessed: October 10, 2009)

Reddy, B.Muralidhar (2001). "Of Religion and Economics”. Frontline. Vol. 18, Issue 11.

Samuelson, Paul (1948). “Economics”. New York: Harcourt and Brace.

Saleem, Shehzad (1992). “Islamic Concept of Taxation”. Renaissance. Vol 02, Issue 10.

Saleem, Shehzad (1995). "Evidence of Muhammad (PBUH) Prophet Hood". Renaissance. Vol 05, Issue 10.

Scott, P.S. (1904). "History of the Moorish Empire". Philadelphia: Lippincott.

Shaikh, Mehmood A. (1990). Towards Interest Free Banking. Lahore. Institute of Islamic Culture.

Siddiqui, Muhammad N. (2002). "The Wisdom of Prohibition of Interest". LaRiba Annual Conference. Los Angeles, C.A. March 30, 2002.

Siddiqui, Muhammad N. (1982).” Monetary Policy - A Review.” International Centre for Research in Islamic Economics. Jeddah: Kind Abdul Aziz University Press.

Smolarski, et al (2006). Permissibility and use of options for hedging purposes in Islamic Finance. Thunderbird International Business Review, Vol: 48, no: 425-433, Wiley Periodicals.

State Bank of Pakistan (2009) Strategic Plan for Islamic Banking 2009, Karachi.

State Bank of Pakistan [2009] Weekly Profile of Broad Money 2009, Karachi.

The Economist. [June 14, 2007]. “Tighter Monetary Policy”. Monetary Policy Section. The Economist Newspaper Limited.

Toutounchian, Iraj (2006). "Integrating Money in Capital Theory: A Legal Perspective. Presented at 7th forum on Islamic finance. Harvard Law School, April 22-23, 2006. 


\section{Proposal for Islamic Economic Framework}

United Nations (2005). "United Nations Development Indicators". United Nations Development Research Group.

Usmani, Dr. Imran A. (2009). "Islamic Bainkary ka aik ta'arruf" [An Introduction to Islamic Banking]. Karachi: Maktaba Ma'ariful Quran.

Usmani, Muhammad Taqi (2003). "Islam Aur Jadid Maeeshat-o-Tijaraht" [Islam and Contemporary Economy and Trade] . Karachi: Maktaba ma'ariful Quran.

Usmani, Muhammad Taqi (2007). "Historic Judgment on Interest”. Karachi: Maktaba Ma'ariful Quran.

Usmani, Muhammad Taqi (u.d). "Looking for New Steps in Islamic Finance”. Retrieved on April 25, 2010, from website: http://www.muftitaqiusmani.com/IFArticles.aspx

Usmani, Muhammad Taqi (2009). "Ghair Soodi Bainkary" [Interest Free Banking]. Karachi: Maktaba Ma’ariful Quran.

Usmani, Imran (2009). Examining the Risk Prudence of Islamic Banks: A Risk Management Perspective. Euro Money. Islamic Finance Review, 2009.

Uzair, Mohammad (1982) Central Banking in an Interest-Free Banking System, in Mohammad Ariff (ed.), Monetary and Fiscal Economics of Islam, pp. 211-235. Jeddah: International Centre for Research in Islamic Economics.

Warde, Ibrahim (2000). Islamic Finance in the Global Economy. Edinburgh University Press: Edinburgh.

World Gold Council [2010]. World Official Gold Holdings 2010, London.

Yu-Hung (1996). "Can Leasing Public Land Be An Alternative Source of Local Public Finance?" (Working Paper): Lincoln Institute of Land Policy. Inventory ID WP96YH2.

Zaheer, Dr. Khalid (1996). "A Critical Look at the Alternatives to the Popular Models of Interest Free (IF) Banking”. Renaissance. Vol 6 Issue 6.

Zaheer, Dr. Khalid (2007). "What is Riba". Retrieved on September 14, 2009, from website:

www.khalidzaheer.com/essays/kzaheer/economic\%20issues/what is riba.html

Zaidi, Akber (2005). “Issues in Pakistan’s Economy”. Karachi: Oxford University Press

Zangeneh, Hamid \& Salam, Ahmed (1993).Central Banking in an Interest Free Banking System. JKAU: Islamic Econ., Vol. 5, pp. 25-36. 